THE. YOUNG・FARMER'S

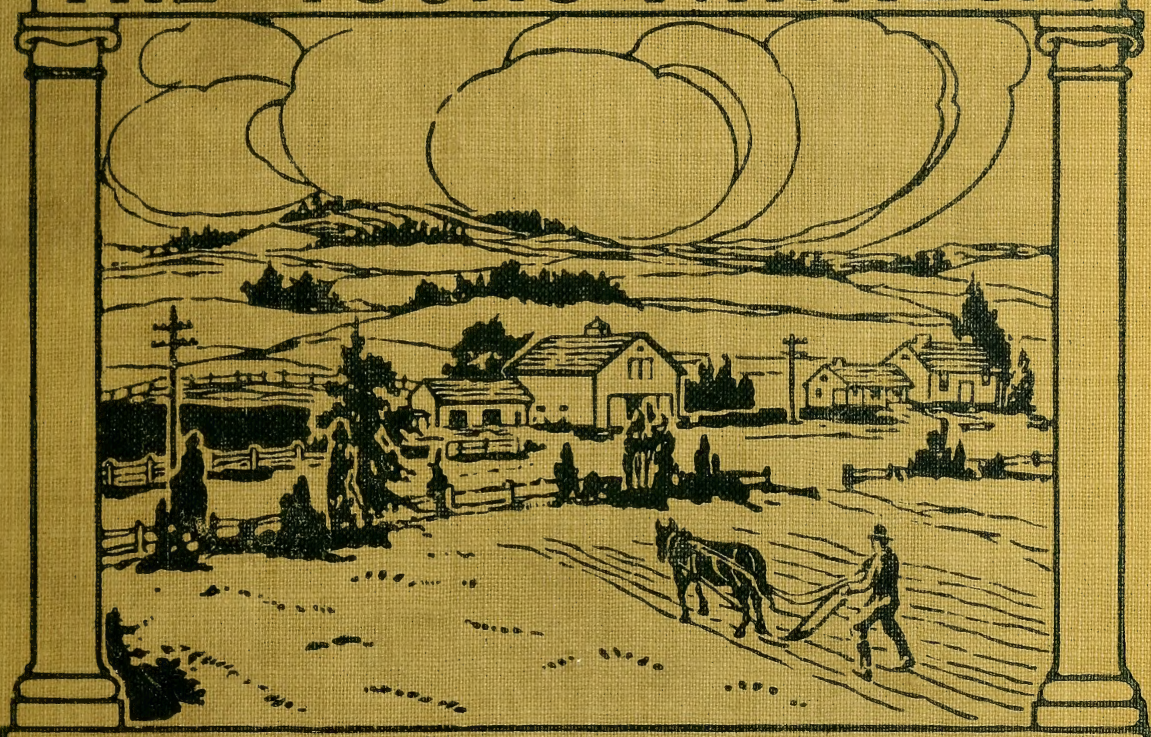

PR $\mathcal{A} C$ T I C $A$ L $\cdot$ LIB R $A$ R Y (6) acil 203 \&o

\&
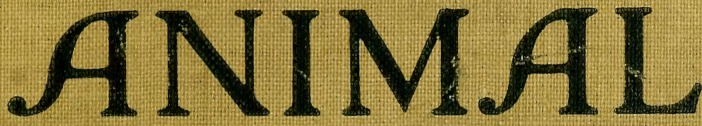

$\frac{12}{12}$

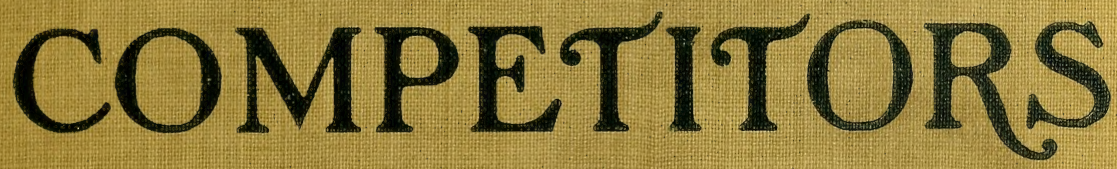
ERNEST $\cdot$ INGERSOLL 

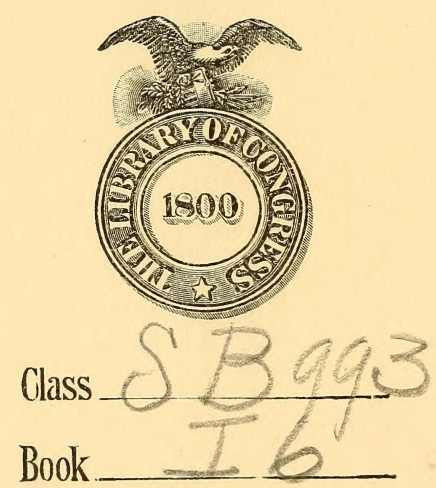

Copyright No.

COPYRIGHT DEPOSiT: 



$$
\text { , }
$$


THE YOUNG FARMER'S PRACTICAL LIBRARY EDITED BY ERNEST INGERSOLL

\section{ANIMAL COMPETITORS}

BY

ERNEST INGERSOLL 


\section{The Young Farmer's Practical Library}

\section{EDITED BY ERNEST INGERSOLL}

Cloth I6mo Illustrated each 75 cents net.

From Kitchen to Garret. By Virginia TERHUNE VAN DE WATER.

Neighborhood Entertainments. By RENÉE B. STERn, of the Congressional Library.

Home Waterworks. By Carleton J. LYNDE, Professor of Physics in Macdonald College, Quebec.

Animal Competitors. By Ernest INGersoll.

The Farm Mechanic. By L. W. Chase, Professor of Farm Mechanics in the University of Nebraska.

The Satisfactions of Country Life. By Dr. James W. Robertson, Principal of Macdonald College, Quebec.

Roads, Paths and Bridges. By L. W. Page, Chief of the Office of Public Roads, U. S. Department of Agriculture.

Health on the Farm. By DR. L. F. Harris, Secretary Georgia State Board of Health.

Electricity on the Farm. By Frederick M. Conlee.

Co-operation Among Farmers. By JoHN Lee. Coulter. 


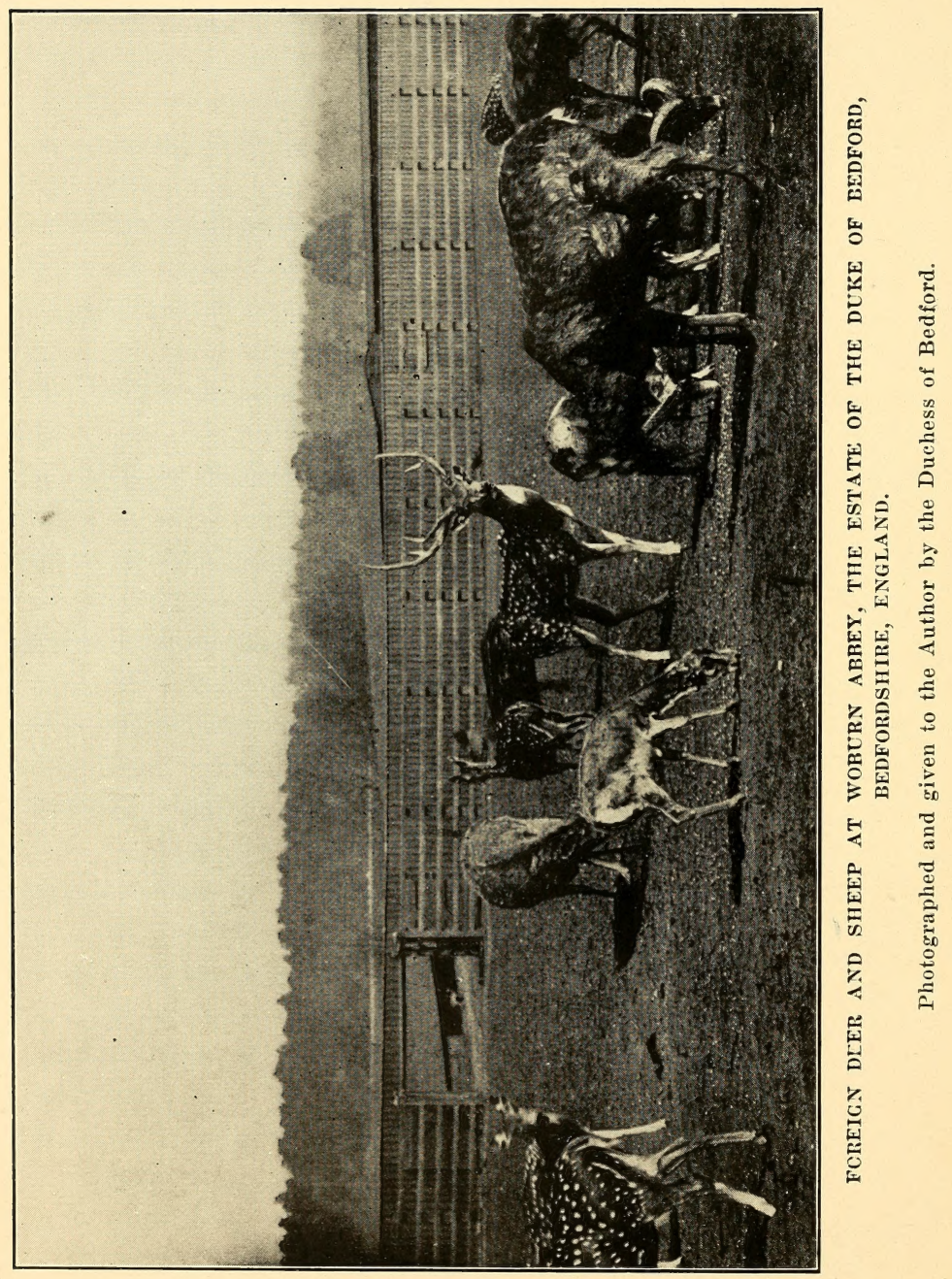




\section{ANIMAL COMPETITORS}

\section{PROFIT AND LOSS FROM THE WILD FOUR-FOOTED TENANTS OF THE FARM}

BY

\section{ERNEST INGERSOLL}

EDITOR OF THE YOUNG FARMER'S PRACTICAL LIBRARY, AND AUTHOR OF "THE LIFE OF MAMMALS" "WIT OF THE WILD," " WILD LIFE OF ORCHARD AND FIELD," ETC.

\section{ILLUSTRATED}

Thew Work STURGIS \& WALTON COMPANY

\section{1}

All rights reserved 


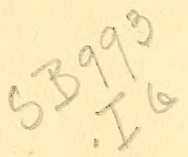

Copyright 1911

By STURGIS \& WALTON COMPANY

Set up and electrotyped. Published April, 1911

C Cl. $A 289699$ 


\section{INTRODUCTION}

\section{BY THE GENERAL EDITOR}

This is the day of the small book. There is much to be done. Time is short. Information is earnestly desired, but it is wanted in compact form, confined directly to the subject in view, authenticated by real knowledge, and, withal, gracefully delivered. It is to fulfill these conditions that the present series has been projected-to lend real assistance to those who are looking about for new tools and fresh ideas.

It is addressed especially to the man and woman at a distance from the libraries, exhibitions, and daily notes of progress, which are the main advantage, to a studious mind, of living in or near a large city. The editor has had in view, especially, the farmer and villager who is striving to make the life of himself and his family broader and brighter, as well as to increase his bank account; and it is therefore in the humane, rather than in a commercial direction, that the Library has been planned. 
The average American little needs advice on the conduct of his farm or business; or, if he thinks he does, a large supply of such help in farming and trading as books and periodicals can give, is available to him. But many a man who is well to do and knows how to continue to make money, is ignorant how to spend it in a way to bring to himself, and confer upon his wife and children, those conveniences, comforts and niceties which alone make money worth acquiring and life worth living. He hardly realizes that they are within his reach.

For suggestion and guidance in this direction there is a real call, to which this series is an answer. It proposes to tell its readers how they can make work easier, health more secure, and the home more enjoyable and tenacious of the whole family. No evil in American rural life is so great as the tendency of the young people to leave the farm and the village. The only way to overcome this evil is to make rural life less hard and sordid; more comfortable and attractive. It is to the solving of that problem that these books are addressed. Their central idea is to show how country life may be made 
richer in interest, broader in its activities and its outlook, and sweeter to the taste.

To this end men and women who have given each a lifetime of study and thought to his or her speciality, will contribute to the Library, and it is safe to promise that each volume will join with its eminently practical information a still more valuable stimulation of thought.

ERnest Ingersoll. 



\section{PREFATORY NOTE}

The writer could hardly claim much originality for this book, were he so disposed. His aim has not been a literary one, but rather to compose a useful handbook of the mammalsthe wild four-footed tenants-of our American farm-lands, from the point of view of the agriculturist, orchardist and ranchman. The United States Department of Agriculture, through its various departments and publications, has from time to time issued information -vast in its sum-in respect to economic zoölogy; and most of the Agricultural Colleges and Experiment Stations in the several States have repeated and supplemented this extensively. The bulk of this proffered matter, however, relates to the ravages of injurious insects, or to the beauty and usefulness of birds-subjects which may receive attention in future volumes in this Library.

The economic importance of the mammals- 
the rats, field-mice, rabbits, gophers, groundsquirrels, muskrats, etc.; the fox, the wolves and the fur-bearers; the deer and their kinhave been appreciated by very few; yet the harm done annually by one unchecked class of them entails a vast waste, while the benefit which might be obtained from another class is lost because their lives are little cared for and their capabilities for profitable exploitation almost wholly neglected.

It is hoped that this book will lead to a reversal of this wasteful and negligent state of affairs; and that by its help the farmer's friends among the wild animals about him may be encouraged and his foes subdued. Thus the account of the agriculturist with his fourfooted competitors may be changed from a needlessly heavy balance on the loss side, to one of profit, reckoned partly in savings and partly in "new business."

My sources of statistical information, especially for the West, have been largely reports of investigations conducted by the Biological Survey. These reports, it is true, have been widely distributed during the past ten years, 
but they have gone out as chapters in forbidding public documents, or else separately in loose pamphlets which in most cases have been speedily lost. It is impracticable for the ordinary man to get copies of them now if he tries, and their usefulness has therefore come to an untimely end. Among them are original and valuable essays by Dr. C. Hart Merriam, Chief of the Biological Survey until his resignation in 1910, when H. W. Henshaw succeeded to his office; Vernon Bailey, the assistant in charge of field investigations; David E. Lantz, Wilfred H. Osgood, E. W. Palmer, Stanley E. Piper, E. W. Nelson, Edward A. Goldman, and others attached to the Department.

Knowing the accuracy and importance of this half-lost material, and also aware that nothing better could be furnished in its stead, I have not hesitated to make liberal use of it, often in its own well-chosen language. It was written for the benefit of the public; and I am confident the gentlemen above mentioned will gladly see it renew its usefulness in the permanent form a bound book affords, and rejoice in the greater force their facts and recommen- 
dations will obtain by being associated in an orderly array. To them belongs credit for the larger part of the facts presented in the pages that follow. I have simply arranged and enforced the material anew in the most suitable form I could devise.

Attention may be called, further, to one novel feature in the book, namely, the detailed instructions as to the cultivation of certain wild animals in captivity as an industry. Among those recommended for this purpose are the deer, for sale alive to parks, and to furnish venison to market; the muskrat for food and skins; the silver fox for its costly pelt, and such other fur-bearers as the mink and skunk. All over the country young men are so situated as to be able to add one or more of these enterprises to their year's work, and to derive from them an attractive addition to the annual income, while contributing in no small degree to the general wealth and welfare of the country.

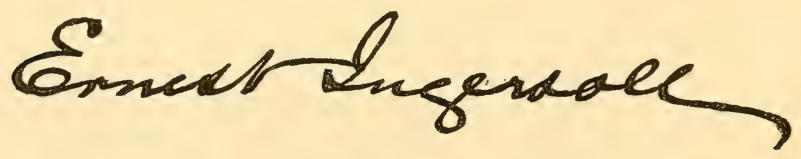

New York, Jan. 1, 1911. 


\section{CON'TEN'TS}

\section{CHAPTER I}

\section{The Pest of Rats}

Varieties of rats-Cost of their board-Destructiveness-

PAGE

Carriers of disease-Breeders of bubonic plague-Precautions and suppression-Need of coöperation . . 3

CHAPTER II

The Pantry Mouse

Dancing mice-Rapid increase-Carrying diseases-Musical mice . . . . . . . . . . . . . . 37

\section{CHAPTER III}

The Meadow-mouse and its Mischief

American voles-Prairie-mice and Pine-mice-Multiplication into plagues-Prevention of plagues-Damage to crops considered-Protection of young trees . . .

\section{CHAPTER IV}

\section{Profit from the Muskrat}

Damage by muskrats-Excellence of muskrat flesh-Fur in demand-Methods of trapping-Cultivation of muskrats . . . . . . . . . . . . . .

\section{CHAPTER V}

Can the Beaver be Saved?

Possibilities and difficulties of rearing captive beavers . 94 xiii 
xiv

\title{
CONTENTS
}

\author{
CHAPTER VI \\ Wood-rats, Pack-rats, Cotton-rats, etc.
}

PAGE

Habits and architecture of wood-rats-Pilfering extraordinary-Destruction by the cotton-rat-Jumping-mice -Kangaroo-rats, etc. . . . . . . . . . 98

\section{CHAPTER VII \\ The Gray Gophers}

Characteristics-Burrowing powers-Injury to crops and young trees-Boring in ditch-banks-Gophers as soilmakers . . . . . . . . . . . . . 112

\section{CHAPTER VIII}

Squirrels, Good ANd BAd

Habits and food of red squirrels-Winter storage of food-Larger squirrels-The flying-squirrel . . . 125

\section{CHAPTER IX}

\section{Ground-SquirRels ANd Prairie-dogs}

Chipmunks and their homes-Striped gophers and spermophiles-Ground-squirrels as carriers of diseasePrairie-dogs . . . . . . . . . . . . . 144

\section{CHAPTER $\mathrm{X}$}

\section{Rabbits, Useful and InJurious}

Rabbit-fiesh good food-Breeding habits-Damage to gardens and orchards-Protection of trees-Pet stock . 164

\section{CHAPTER XI}

\section{Suppression of Rodents as Pests}

Unwise destruction of natural enemies-Poisoning and Fumigation-Difficulties to be overcome . . . . 184 


\section{CONTENTS}

CHAPTER XII

Moles, Shrews ANd Bats

Moles misunderstood-Trapping moles and shrews-Bats and their guano deposits : . . . . . . . . 194

\section{CHAPTER XIII}

\section{Foxes AND Fox-FARMING}

American foxes-Varieties of fox-fur-Arrangement of a fox-rearing establishment-Care of captive foxes-Improving the stock . . . . . . . . . . . 206

\section{CHAPTER XIV}

\section{Gray Wolves and Coyotes}

Wolf traits-Good and bad food-habits-The coyote a pest to sheep-ranches-Directions for fencing . . . . 232

\section{CHAPTER XV}

\section{The Fur-bearers and thetr Culture}

North American fur-bearers-Ermine weasels-The weasel as a mouser-Value of the mink-Rearing minks in captivity-The otter, badger and skunk-Skunk-farming

\section{CHAPTER XVI \\ Raising Deer for Profit}

Native deer-Domestication and breeding-Venison and buckskin-Wild horses, bighorn, antelopes, etc. . . 273

\section{CHAPTER XVII}

\section{Directions for Poisoning and Trapping}

Waste of effort and money-Formulas for preparing animal poisons-Trapping in various ways and places . 288 

ANIMAL COMPETITORS 



\section{ANIMAL COMPETITORS}

\section{CHAPTER I \\ THE PEST OF RATS}

We have in the United States three foreign rats, all injurious to health and property.

1. The brown house-rat (Mus norvegicus), called also gray rat, house-rat, barn-rat, wharf-rat and Norway rat, and, in England, Hanoverian rat. Its average total length is about 16.4 inches, of which 7 inches belongs to the tail, and it usually weighs less than a pound, though specimens have been known so much larger as to weigh 24 to 28 ounces. The general color is grayish-brown above and whitish below, the long overhairs of the back having black tips. The head is shorter, the muzzle more blunt, the ears smaller and the tail relatively shorter than in the other species. It is 
spread all over the continent, except the Utah basin.

2. The black rat (Mus rattus), smaller than the brown rat, and sooty or slaty black, paler on the under parts. Like the brown rat, it is of Oriental origin and seems to have preceded the former in its immigration into western Europe and thence to this continent. It was carried from Europe to Spanish America about three and a half centuries ago, and thence spread northward to the English colonies. Upon the arrival of the brown rat in North America toward the end of the 18th century it began to decrease, and is now rare, surviving only in scattered colonies, but remain numerous in many parts of the West Indies, Middle and South America, Hawaii, etc.

3. The roof-rat (Mus alexandrinus), similar to the brown rat in form and habits, but grayer above, and yellowish white on the feet and abdomen. Its history is much like that of the black rat, but it has held its own better against the dominance of the brown rat, inhabits sea-going ships, and has established 


\section{THE PEST OF RATS}

itself in all the warmer parts of the world. It is still prevalent in our South Atlantic States, in the West Indies and in South America. The tame white rats sold as pets are mostly of this and the black species.

In habits these three rats are similar, with the important exception that the black rat and the roof-rat (which some zoölogists consider merely varieties of one species), do not burrow under foundations, etc., as does the brown rat. On the other hand they are far more agile and addicted to climbing, - a decided advantage in the tropics where a large part of their food is obtained from trees, in whose branches they frequently lodge their nests; and are less able to withstand cold than the brown rat, which survives arctic winters in whaling ships, apparently without distress. They are also less prolific, having only ten mammæ to the brown rat's twelve, and bearing on the average only about five young at a birth to the other's eight. This difference in prolificacy alone would account for the great dominance of the brown rat, at least in North America; and it is to that species-the rat, par excellence 
- that we devote our attention in considering the relation it bears to human welfare, especially on the farm.

"The rat," says Lantz, succinctly, "is the worst mammalian pest known to man. Its depredations throughout the world result in losses amounting to hundreds of millions of dollars annually. But these losses, great as they are, are of less importance than the fact that rats carry from house to house and from seaport to seaport the germs of the dreaded plague."

This enormous evil can be cured only by being prevented; and it is not only to the personal interest of every man, but a part of his public duty, to do all in his power to stamp out a pest which is not only costing the country many millions of dollars in damages annually, but is constantly threatening each of us with horrid diseases.

History. In order to destroy the rats we have, and to guard against their increase on our own premises, at least, we must become acquainted with the haunts and habits of the animal. 


\section{THE PEST OF RATS}

The early history of the brown rat is practically unknown. Various modern writers have asserted that it came originally from Persia or India; but W. T. Blanford, a leading zoölogist of British India, states that it is at present unknown in Persia, and that, as concerns India, the black rat is the generally distributed species, while the brown rat is found only along the coast and the navigable rivers. This seems to imply that the latter is a comparatively recent immigrant into India; and other evidence seems to show that its original home was northward of the Himalayan ranges. Its resistance to cold supports this hypothesis. It seems to have entered Europe first by crossing the Volga into Russia in hunger-driven hordes in 1727, but it reached England from some eastern port a year or two later, coincident with the accession of George I to the British throne. The general, but erroneous, belief in Great Britain that it was introduced from Norwegian timber-ships gives it the name "Norway" rat there, as I explained in my Life of Mammals. "It reached our eastern ports in 1775 and was popularly credited to the hated 
Hessian soldiers, - a queer echo of the London idea that it came there with the Hanoverian train of the present reigning house. By 1830 it had reached the Mississippi, and by 1857 , at least, was numerous in California." Now no part of the country save the western deserts is free from these pests; and competent judges estimate their numbers as at least five times that of the human population, with which they more than keep pace as widening civilization more and more favors their support and increase.

Fecundity of the rat. A consequence is that from time to time there is an overflow of rats from one locality or region to another which gives us a glimpse of the unseen crowd in the midst of which we live. "In 1903, a multitude of migrating rats spread over several counties of western Illinois. They were noticed especially in Mercer and Rock Island counties. For several years prior to this invasion no abnormal numbers were seen, and their coming was remarkably sudden. An eyewitness to the phenomenon informed the writer 


\section{THE PEST OF RATS}

that as he was returning to his home by moonlight he heard a general rustling in the field near by, and soon a vast army of rats crossed the road in front of him, all going in one direction. The mass stretched away as far as could be seen in the dim light. These animals remained on the farms and in the villages of the surrounding country, and during the winter and summer of 1904 were a veritable plague. A local newspaper stated that between March 20 and April 20, 1904, Mr. F. U. Montgomery of Preëmption, Mercer county, killed 3,435 rats on his farm."

This enormous multiplication is due to the animal's adaptability to climate, its omnivorousness, its habit of burrowing, its strength and cunning in withstanding and outwitting enemies, and, most of all, to its astonishing fecundity, especially where food is abundant.

This rat breeds in the temperate parts of this country from three to five times a year, the female bringing forth each time from 6 to 20 young. Mr. Lantz concludes from such data as are available that in the vicinity of Wash- 
ington the average litter is 10. A pair and their progeny breeding three times a year would, thus, if all remained alive, produce a population of more than 20,000,000. "Of course, such results never occur in nature. Apparently not nearly half the rats born are females; at least, among mature rats the males greatly predominate. Then, too, the life of young rats, as well as that of the old, is a continuous struggle for existence. Disease, the elements, natural enemies, the devices and cunning of man, and even cannibalism are continually at work to reduce their numbers."

The young are born, after a gestation period of 21 days, in a burrow dug in the ground under buildings, piles of lumber or wood, beneath strawstacks, etc., or simply bored into a streambank. They are naked and blind at birth, but develop with great rapidity.

What it costs to board our rats. The damage done by rats over so great an area as the United States or Canada, is incalculable. David E. Lantz, in the document from which I am quoting freely, summarizes their destruction thus : 


\section{THE PEST OF RATS}

"The brown rat is practically omnivorous. The statement applies as well to the black rat and the roof rat. Their bill of fare includes seeds and grains of all kinds, flour, meal, and food products made from them; fruits and garden vegetables; mushrooms; bark of growing trees; bulbs, roots, stems, leaves, and flowers of herbaceous plants; eggs, chicks, ducklings, young pigeons, and young rabbits; milk, butter, and cheese; fresh meat and carrion; mice, rats, fish, frogs, and mussels. This great variety of food explains the ease with which rats adapt themselves to almost every environment.

"Experiments show that the average quantity of grain consumed by a full-grown rat is fully 2 ounces daily. A half-grown rat eats about as much as an adult. Fed on grain, a rat eats 45 to 50 pounds a year, worth about 60 cents if wheat, or $\$ 1.80$ if oatmeal. Fed on beefsteaks worth 25 cents a pound, or on young chicks or squabs with a much higher prospective value, the cost of maintaining a rat is proportionately increased. Granted that more than half the food of our rats is waste, the average cost of keeping one rat is still upward of 25 cents a year.

"If an accurate census of the rats of the United States were possible, a reasonably correct calculation of the minimum cost of feeding them could be made from the above data. If the number of rats supported by the people throughout the United States were equal to the number of domestic animals on the farms-horses, cattle, sheep, and hogs-the minimum 
cost of feeding them on grain would be upward of $\$ 100,000,000$ a year. To some such enormous total every farmer, and indeed every householder who has rats upon his premises, contributes a share.

"But the actual depredations of rats are by no means confined to what they eat. They destroy fully as much grain as they consume, and they pollute and render unfit for human consumption a much larger proportion of all other food materials that they attack. In addition, the damage they do to property of other kinds is often as great as that done to food supplies.",

Destructiveness of rats in the fields. The rat in America is usually thought of as vermin in the house and barn, so that little notice is taken of its destructiveness in the fields which Europeans understand very well. Cultivated grains may be regarded as the favorite food. The animals dig the seed from the ground as soon as sown, eat the tender sprouts when they appear, and later feast upon the maturing crop. After harvest they attack grain in shock, stack, and mow, and when thrashing is over, in crib, granary, elevator, mill, and warehouse. Indian corn seems especially to suffer from their depredations. They climb the stalks and strip the cobs of the milky kernels; and if cut corn 
is left in shocks, especially near drains or other rat-harbors, it is likely to be ruined.

Shortly after the settlement of the Bermudas by the British, the colony was infested with rats, which, in the space of two years, had increased so alarmingly that none of the islands were free from them, and even fish were taken with rats in their bellies. A writer in the Academy recalls some of the horrors of this plague of rats. The rats, we are told, had nests in almost every tree, and burrowed in most places in the ground like rabbits. They devoured everything that came in the way-fruits, plants, and even trees. Where corn was sown they would come by troops in the night and scratch it out of the ground; 'nay,' writes a contemporary chronicler, 'they so devoured the fruits of the earth that the people were destitute of bread for a year or two.' Every expedient was tried to destroy them. Dogs were trained to hunt them, who would kill a score or more in an hour. Cats, both wild and tame, were employed in large numbers for the same purpose; poisons and trapsevery man having to set twelve traps-were brought into requisition; and even woods were set on fire, to help to exterminate them. Every letter written at this period by the plague-stricken colonists contains some account of the dreadful scourge. 'Our great enemies the rats threaten the subversion of the plantation,' writes one colonist in July, 1616. 'Rats are a great judgment of God upon us,' wrote another a year later. 'At last it pleased God, but by what 


\section{4}

ANIMAL COMPETITORS

means is not well known, to take them away, insomuch that the wild eats and many dogs that lived on them were famished.' There was universal joy at the sudden removal of such destructive vermin; and the all but despairing planters were enabled once more to resume their neglected occupations with spirit and energy.

Much more recently, rats became such a plague in the sugar-plantations of the West Indies, and especially in Jamaica, that the East Indian mungoosa fierce, weasel-like civet-was introduced. This animal cleared out the rats, but speedily became in other directions such a nuisance that its destruction had to be effected in order to save the poultry and birds of the Island.

Rats often damage corn in cribs. Too frequently these receptacles for grain are built close to the ground, and rats live under the floor, and soon get access to the grain. They shell the corn, eating the softer part of the kernel and wasting much more than they consume. They carry the grain to subterranean burrows and bring up into the crib moist soil, which induces mold. Similarly they eat the small grains in the field and take toll of the granary and feed-box,-often 5 to 10 per cent. 


\section{THE PEST OF RATS}

of feedstuffs, malt and the like; while no pest of the sugar-cane is much more to be feared.

The damage done by rats to fruits and vegetables while stored in cellars and pits is well known. They attack ripe tomatoes, melons, cantaloupes, squashes, pumpkins, sweet corn, and many other vegetables in the field, and the depredations are often attributed to rabbits. Rats are fond of nearly all small fruits, even climbing grape-vines, blackberry-canes, and currant-bushes to obtain the ripe fruit; and often feed upon ripe apples, pears, cherries, and so forth.

Rats are recognized pests of the greenhouse and the plant-propagating pit, where they attack seeds, bulbs, leaves, stems and flowers. Of flowering bulbs the tulip suffers most and hyacinths also are eaten, while narcissus bulbs are apparently immune to attack. Carnations seem especially liable to destruction.

Destructiveness to poultry and game. Very serious is the loss due to rats entering badly constructed hen and pigeon houses,-probably greater, in Mr. Lantz's opinion, than that in- 
flicted by foxes, minks, weasels, skunks, hawks and owls combined; but mostly one or all of these are made to take the blame.

"Not long since, in a published account of depredations on poultry, the damage was attributed to a skunk. The statement was made that both eggs and young chicks were taken from under a sitting hen without disturbing her. This is a trick peculiar to the rat, and it is evident that a mistake was made as to the identity of the thief.

"Where rats are numerous in springtime, they often prey upon young chicks, eapturing them in the nest and in and around the coops. I have known them to take nearly all the chicks on a large poultry ranch, and, in the same neighborhood and over a large territory, to destroy nearly 50 per cent. of the season's hatching. Young ducks, turkeys, and pigeons are equally liable to attack, and where rats are numerous are safe only in rat-proof coops.

"A writer in a western agricultural paper states that in 1904 rats robbed him of an entire summer's hatching of three or four hundred chicks. A correspondent of another journal says, 'Rats destroyed enough grain and poultry on this place in one season to pay our taxes for three years.' When it is remembered that the poultry and eggs produced each year from the farms of the United States have a value of over $\$ 600,000,000$, it will be seen that even a small percentage of loss aggregates a large sum." 
In Europe the rat is the bane of gamekeepers who try to preserve broods of pheasants and other game. Our wild game-birds are less molested and perhaps better able to protect themselves; yet our grouse and quail must suffer, for rats eat the eggs of ground-nesting song-birds, but the real offender is seldom even suspected.

Rats often gnaw the hoofs of horses until the feet bleed. Brushing the hoofs with dilute carbolic acid is a preventive. They have been known to kill young lambs and pigs, and to attack very fat hogs and eat holes in their bodies, causing death. Farrowing sows have been killed by rats gnawing their teats until blood poisoning resulted.

Rats damage buildings and stored goods. Interest in the damage done to stored goods and merchandise belongs more to the city warehouseman than to the countryman, but the latter is well aware that old harness and gear of all sorts with leather about it, any grainbags and similar articles must be protected from rats. Damage to houses and barns is, 
however, a matter of grave interest to inhabitants of the village as well as of the city. Quoting Lantz again,-

"The damage to houses and furniture by rats constitutes a large item. They burrow under foundations or through the plaster in a stone wall and admit streams of water that eventually weaken or undermine the structure itself. They seem to be able to penetrate almost everything except stone, brick, cement, glass, and iron. They gnaw into a grain bin, or through a wainscoting, a floor, or a door in a single night In the same way they enter chests, wardrobes, bookcases, closets, barrels, and boxes for the stores within. Almost every old dwelling in the country bears abundant evidence of its former or present oceupancy by rats. Rats gnaw through lead pipes or wooden tanks to obtain water, and sometimes before the leak is discovered, ceilings, wall decorations, and floor coverings are flooded and practically ruined. All this is waste of a tangible kind and a constant drain on the prosperity of the people."

Then there is the ever-menacing devastation from fires due to rats carrying matches into their nests and there igniting them by chewing them, or simply by overheating; or due to their gnawing the insulation from electric wires-a surprisingly frequent origin of fires of late years. 
Rats as carriers of disease. Finally, rats are always a menace to health, and may become the agents of the dissemination of the most dreadful and virulent of diseases-the Asiatic plague, which has more than once decimated the civilized world. It has been calculated that $25,000,000$ of persons perished in an epidemic of this character which swept over the world in the 14th century; and it did not require the literary genius of a De Foe to perpetuate the memory of the awful visitation which almost depopulated London and set all Europe in mourning toward the end of the 16th century. Even then, in the cloud of mystery, superstition and horror of fear which made most men blind and helpless, the truth was dimly recognized by a few,-namely that it was not the wrath of God nor the malignancy of some evil spirit nor a miasm from earth or sea that struck men down, but the communication of disease from the sick to the well. This, it was observed, could be effected not only by contact with human victims, but that the contagion was caught and passed on by all the small animals about a house. Hence orders were issued that 
not only rats, mice, and small vermin of all sorts should be killed, but also dogs and cats. An ordinance by the authorities at Winchester, England, in 1583, is typical of many others issued in British towns, viz.:

"That if any house within this cytie shall happen to be infected with the Plague, that thene every persone to keepe within his or her house every his or her dogg, and not to suffer them to goo at large. And if any dogge be then founde at large, it shall be lawful for the Beadle or any other person to kill the same dogg, and that any owner of such dogg going at large shall lose six shillings."

Among the records of King's Lynn, under May, 1585, appears this:

"For as muche as it hath pleased Allmightie God to begynn to send us his visitacion with sickness amongst us, and that dogges and cattes are thought verie unfitt to be suffered in this tyme. Therefore Mr. Maior, aldermen, and common councell have ordered and decreed that every inhabitant within the same Towne shall forthwith take all their dogges and yappes and hange them or kill them and carrye them to some out-place and burye them for breadings of a great annoyance. And likewise for cattes, if there be any nigh unto any house or houses visited with sickness. . . It is ordered that the eattes shall furthwith be killed in all such places." An exception was 


\section{THE PEST OF RATS}

made in favor of any "dogge of accompte." Such a one was allowed to be kept if "kenelled or tied up or led in a lease."

As often happens, a fact was clearly perceived and acted upon beneficially long before the philosophy of it was comprehended.

Rats responsible for the plague. It was not until the very end of the last centuryscarcely a dozen years ago, that the suspected truth of the real nature of the plague was discovered through scientific studies of the disease which then appeared in a most threatening form in India. It was determined that of the several phases of plague the most common is that which produces swellings or "buboes" on the body of the victim, and hence is called bubonic plague. This is rarely communicated direct from man to man, but through the medium of insects which suck the patient's blood and then, filled with the diseased blood in which are floating the deadly bacilli (Bacillus pestis) which produce the disturbance, pierce the skin of some other creature and leave more or less of these plague-germs in the puncture.

Any blood-sucking bug, as, for example, the 
bed-bug, may do this; but the most common agent is the flea.

Another fact is that the rat seems especially susceptible to the disease; and, indeed, it is be-

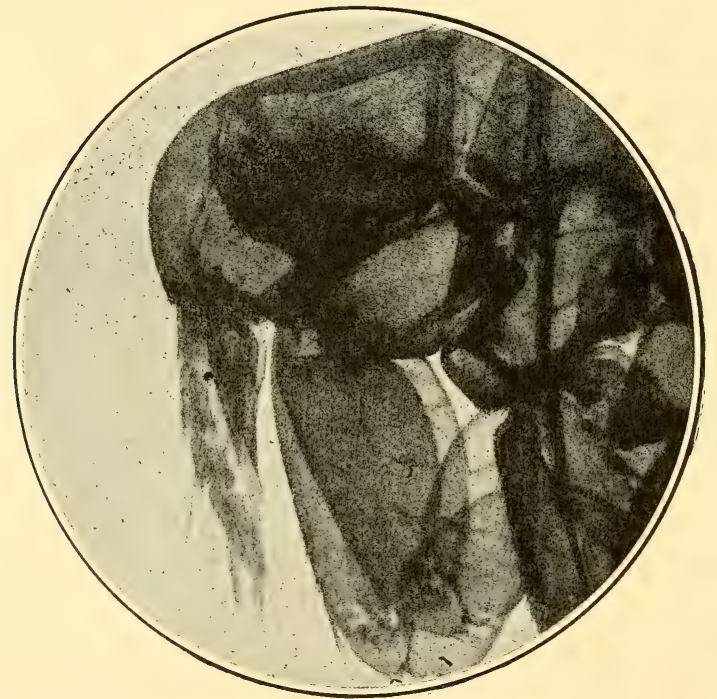

MOUTH-PARTS OF A RAT-FLEA, SHOWING WHERE BACILLI MAY CLING AND BE CARRIED INTO THE NEXT WOUND.

From Doane's "Insects and Disease." By Permission of Henry Holt \& Co.

lieved that it was originally a disease of this rodent. Rats abound in fleas, and, as is the case with most furry or feathered animals, have a species peculiar to their race. This 
rat-flea will bite and communicate the disease from rat to rat, and an outbreak of plague among men is usually preceded by an epidemic among the rats. The rat-flea does not bite man; but those which live on human beings will thrive on rats and may return from an infected rat to a human host if opportunity offers. The fleas of dogs and cats will temporarily live on the skin of both rodents and human beings, and may thus take a part in the transmission of plague. The fleas usually leave a rat or other animal as soon as it dies, and, with their stomachs full of plague-bacilli, with others clinging to their proboscis and sucking lips, they seek new hosts. The new host, whether rat, or some other animal, or perchance a human being, is soon bitten with these infected mouths, and thus receives the germs of the malady.

Those who wish to pursue the study of this matter in further detail will find a very full exposition of it, and of the general relations of insects to common diseases, in R. W. Doane's Insects and Disease (New York, Holt, 1910). 


\section{4}

It is now understood that the first thing to do when a case of plague is brought to some port in a ship sailing from the Orient is to exterminate the rats of the locality; and the best preventive against this and other afflictions getting a foothold anywhere, is to keep the rats down. The Japanese were quick to take advantage of the new knowledge, and by the fierce crusade they waged against the wharf-rats in their ports prevented a spread of bubonic plague, always threatening them, in the armies they sent into Manchuria. In this way, too, by a vigorous crusade against the animal in California, in which many hundreds of thousands were trapped or poisoned, the plague was recently eradicated in San Francisco before it had reached alarming proportions.

Rats and trichince. But rats disseminate diseases other than bubonic plague. Trichinosis among swine is probably perpetuated entirely by rats, since trichinæ in the hog can result only from its eating the flesh of animals infested with the parasite. The only two animals of the farm known to be subject to this 


\section{THE PEST OF RATS}

parasite are the rat and the hog itself. Pork becomes trichinous, then, only when swine eat the flesh of infected rats or hogs. Country slaughter-houses, where rats are abundant and swine are fed on offal, are the chief sources of trichinous pork. That the danger from this source has not been confined to the rural slaughtering-places alone, is shown by the investigation conducted by the Biological Survey in 1909 into the "rat-nuisance," said to exist about the great packing-houses in Chicago and St. Louis. The older establishments were found to be infested with rats, causing a serious aggregate loss, and endangering both the health of the workmen and the wholesomeness of the product; but this state of things has been greatly improved, and new buildings are designed to be rat-proof.

Rats creep through drains and step about in all sorts of filth; and to their feet and fur clings slime which may be loaded with germs of typhoid, diptheria and any other of the malignant list of diseases due to bacilli that develop in darkness and filth. Consequently 
no household is safe into which rats may wander and leave the seeds of disease brought from the gutter.

In view of these facts it would seem important that every man should attempt to free his property of these undesirable tenants, which, so far as we can see, make no return whatever for the damage and depredation of which they are guilty.

Methods of suppression. It is perhaps too late to get rid of the rat altogether, but it is not too late to subdue him and prevent a great part of the evils that follow his presence. How shall it be done?

First, try to destroy or drive away those rats you have. Seek out their holes, runways and lodging-places, clean them out and stop them up so far as you are able. The cunning of the rascals is great and they will shift their quarters or invent new means of access and ways of attack with discouraging ingenuity and persistence, which you must endeavor to match. Untiring watchfulness and work will win.

Trapping, if intelligently pursued, will cap- 
ture a great many. The old-fashioned figure-4 trap, dropping a box, or better, a deadfall, is often highly effective. Several sorts of steel traps may be used to advantage; and in the last chapter of this book will be found descriptions of various forms and directions for baiting and setting them.

Poisoning will clear out the creatures more rapidly and effectively but can hardly be used except about barns and out-buildings, and even there should be done intelligently and with certain precautions. Therefore instructions as to the best means and methods of poisoning will also be found in the last chapter.

While endeavoring to kill off the rats by these various methods, precautions should be taken against their return. Their runways and harboring places must be sought out and made untenable. The wisdom of stopping up all holes by which they enter houses, barns or cellars, need hardly be mentioned to commonsense readers. Freshly slaked lime placed in their dry burrows and runs is effective; or fresh thin whitewash to be poured into them. A strong solution of copperas is good, and gas- 
tar daubed about their holes, as also is caustic potash. Where burrows are discovered in banks or fields the inmates may be suffocated by pushing into the holes wads of rags saturated with bisulphide of carbon, as is practiced against gophers; but this is of little use in buildings, for it escapes too easily.

Rat-proof construction. All new or reconstructed buildings should be made rat-proof. This is best done by the use of cement. Even then, when foundations and walls are made of tight concrete, care must be taken lest drains and other openings admit them. Outer doors, especially those that give upon alleys, should not be left open. Basement and cellar windows of barns, stables, chicken-houses, etc., should be screened with wire, so that they may be left ajar for ventilation without danger. Inner doors to vestibules are of great assistance. Even old cellars may be made rat-proof by the use of cement at small expense.

When wooden walls are built upon proper foundations, the building may be made proof against these and other noxious visitors by 


\section{THE PEST OF RATS}

filling the space between the sheathing and the lath for about a foot with concrete.

Rats frequently enter houses from sewers by way of soil-pipes leading into water-closets, but this can be guarded against by care in construction and the use of water-traps.

"Almost everywhere, in country, village, and city, the wooden floors of sidewalks, areas, and porehes are commonly laid upon timbers resting upon the ground. Under these floors rats are safe from most of their enemies. Only municipal action can completely remedy these conditions, but all such rat-harbors should be destroyed and replaced by cement floors. Considering durability, healthfulness, and other advantages, this material is the cheapest that can be used. The floors of wooden porches should always be well above the ground. Rats often undermine brick walks or areas.

"Granaries, corncribs, and poultry-houses may be made rat-proof by a liberal use of concrete in the foundations and floors; or the floors may be of wood resting upon concrete. Objection has been urged against the use of concrete floors for horses, cattle, and poultry, because the material is too good a conductor of heat, and the health of the animals suffers from contact with floors of this kind. In poultryhouses, dry soil or sand may be used as a covering for the cement floor; and in stables, a wooden floor 
resting on the concrete is just as satisfactory so far as the exclusion of rats is concerned."

Keeping food from rats. The general ratproofing of buildings is the most important step in limiting the food supply of rats. The effect of an abundance of food on the breeding of rodents has already been mentioned. Well-fed rats mature quickly, breed often, and have large litters of young. Besides limiting reproduction, scarcity of food will make the measures to destroy the animals by traps, poisons, or bacterial cultures far more effective. But since much of the animals' food consists of garbage and other waste materials, offal of any kind must be so disposed of that rats can not obtain it. The best method is by burning it. The management of slaughter-houses in the country, in particular, needs reform. It is a common practice to leave offal of slaughtered animals to be eaten by both rats and swine. Such places are not only centers of rat-propagation, but are the chief means of perpetuating trichinæ in pork. All this should be changed in fact and by law. The offal should be promptly cremated or otherwise disposed of. There is 
no reason why country slaughter-houses should not be as cleanly as are the abattoirs of a modern city.

Disposal of dead rats. Finally, the bodies of dead rats should never be handled with the bare fingers, or thrown out to be eaten by dogs or pigs or other animals; for they may contain, as has been shown, the germs of dreadful diseases. They should be burned, or else turned to account by being buried at the foot of grape-vines or young trees, for which they will make an excellent fertilizer.

Four-footed enemies of the rat. A word as to the assistance animals may give in killing off and keeping down the rats. How greatly the increase of all rodents is due to the destruction of the various wild mammals, birds and reptiles, that prey upon them, will be shown hereafter. Hawks, owls, weasels and skunks dispose of a great number of rats in rural districts, and might take many more if they were permitted. Skunks in particular are a most valuable help in this direction-both the large northern skunks and the small spotted species of the South and West-and will, if allowed, 
speedily clear a place of its rats and mice. Unfortunately they are seldom allowed to tenant the premises without being molested by either dogs or men. When thus disturbed, the skunks emit the characteristic secretion, which is almost their only defense against enemies. Undisturbed, they are quite inoffensive and will stay about the farm-buildings until rats and mice are no longer to be had. Skunks usually hunt by night, and hence poultry properly housed is safe from them. It is the loose, uncared-for hens that suffer.

The same may be said of weasels, which will follow a rat into its burrow, and seem to take such delight in slaughtering it that no rats can be found shortly after a weasel or two have taken up their quarters in the place. The drawback to their good work is, that they are fond of poultry and clever in getting it. The same may be said of minks; but a rat-proof hen-house is also weasel-proof.

Farm ferrets, like weasels (of which they are a larger cousin) are inveterate foes of rats, but their value under ordinary circumstances is overestimated. 


\section{THE PEST OF RATS}

"For effective work," says one who knows, "they require experienced handling and the additional services of a dog or two. Dogs and ferrets must be thoroughly accustomed to each other, and the former must be quiet and steady instead of noisy and excitable. The ferret is used only to bolt the rats, which are killed by the dogs. If unmuzzled ferrets are sent into rat retreats, they are apt to make a kill and then lie up after sucking the blood of their victim. Sometimes they remain for hours in the burrows or escape by other exits and are lost. There is danger that these lost ferrets may adapt themselves to wild conditions and become a pest by preying upon poultry and birds."

Cats, as a rule, are not of much use. Most of them are too well-fed, and will be afraid of, or not take the trouble to pursue rats, although they may be excellent mousers.

A couple of good terriers, however, will work wonders in freeing one's premises if trained to rat-catching. The ordinary farmer's big cur is of no use for this purpose-and little for any other; but a Scotch, Irish or fox terrier, properly taught, will take pride in the work, 
and catch a surprising number of victims until all are frightened away.

Coöperation necessary to subdue the pest. Little that is really effective can be done, however, without coöperation in each district. ${ }^{1}$ To destroy the animals on the premises of a single farmer in a community has little permanent value, since they are soon replaced from near-by farms. If, however, the farmers of an entire township or county unite in efforts to get rid of rats, much more lasting results may be attained. Such organized efforts repeated with reasonable frequency are very effective.

Coöperative efforts to destroy rats have taken various forms in different localities. In cities municipal employés have occasionally been set at work hunting rats from their retreats with at least temporary benefit to the community. Thus, in 1904, at Folkestone, England, a town of about 25,000 inhabitants, the corporation employés, helped by dogs, in three days killed 1,645 rats. A better example is reported from India, where coöperative work

1 See Coöperation among Farmers, by Prof. John Lee Coulter. In this Library, 1911, 75 cents. 
has prevailed over large districts. Thus in the Punjab more than 625 centers of population, including large towns, were systematically cleared of rats in 1908, the actual number known to have been destroyed reaching 4,116,334, while large numbers were poisoned and escaped to die. The result in diminution of the endemic plague and other diseases was most marked.

Side-hunts in which rats are the only animals that count in the contest have sometimes been organized and successfully carried out. At New Burlington, Ohio, a rat-hunt took place November 26, 1866, in which each of the two sides killed over 8,000 rats, the beaten party serving a Thanksgiving banquet to the winners.

At about the same period county agricultural societies sometimes offered prizes to the family presenting the largest number of rats' tails as evidence that the animals had been destroyed. Even as late as May 2, 1907, in one of the counties of Kentucky, by general consent, the day was set apart for killing rats, and, according to newspaper report, was quite generally observed. There is danger that organized rat-hunts will 
be followed by long intervals of indifference and inaction. This may be prevented by offering prizes covering a definite period of effort. Such prizes accomplish more than municipal bounties, because they secure a friendly rivalry which stimulates the contestants to do their utmost to win.

In England and some of its colonies contests for prizes have been organized to promote the destruction of the European house-sparrow, but many of the so-called "sparrow clubs" are really sparrow and rat clubs, for the destruction of both pests are avowed objects of the organization. A sparrow club in Kent, England, secured the destruction of 28,000 sparrows and 16,000 rats in three seasons, by the annual expenditure of but $\$ 29.20$ in prize money. Had ordinary bounties been paid for this destruction, the tax on the community would have been about $\$ 1,200$, 


\section{CHAPTER II}

\section{THE PANTRY MOUSE}

THE house-mouse (Mus musculus) needs no description. The only native species with which it can be confused is the harvest-mouse, from which it may be readily distinguished by its larger size and by the plain or ungrooved upper incisors. Like the rat it is a native of the old World, very fertile, adaptable and hardy, and from time immemorial has followed civilization so closely that it soon becomes established in any settled region. It is therefore a world-wide nuisance, but by no means so great or difficult a one as is the rat.

Characteristics.-The little house-mouse can hardly be confused with any other, for its ashgray coat, becoming gradually lighter and often yellowish on the under parts, has furnished the language with a distinctive term, "mouse-color"; and its pointed nose, large 
ears, half an inch long, very small eyes, and long naked tail, are unlike those of any native mouse. Its total length is about 7 inches, $31 / 2$ of which belong to the tail. Its molar teeth have each three tubercles, instead of two, as in our own wood-mice; and its incisors are ungrooved, by which, at any rate with the aid of a magnifying glass, the marks of its biting are readily identified.

Its gray protective coat has seemed satisfactory under all circumstances, for there is no perceptible difference between representatives of the species in the four quarters of the globe. In general the type seems singularly invariable, only one or two varieties having arisen, such as the queer rhinoceros mice which appeared in England some years ago, and took their name from their hairless, deeply-folded skin which gave them the appearance of miniature rhinos. This fixity of type may be due in part to the fact that every country has received a constant immigration of fresh blood by means of ships and other conveyances.

Japanese dancing-mice. One strange variety, however, has arisen, probably in China 
from which it spread long ago to Japan, whence we have lately derived the specimens now commonly sold in the animal-stores of our cities under the name of dancing or waltzing mice. They are small in size, pied black and white in a great variety of patterns, and are extremely agile and amusing. Their distinguishing peculiarity, however, is their constant whirling about, so that a lot of them together seem like a company of dancers waltzing busily to some music unheard by us.

The origin and extraordinary behavior of this astonishing race of mice has been the subject of much study, which has been summed up and extensively added to by Prof. Robert M. Yerkes of Harvard University in a book entitled The Dancing Mouse, a Study in Animal Behavior (New York, 1907). He regards it as highly probable that the Chinese took advantage of some deviation in captive mice from the usual form to develop a special race by means of careful and patient natural selection. "The dancing tendency is such in nature as to unfit an individual for the usual conditions of mouse existence, hence, in all probability, human care 
alone could have produced and preserved the race of dancers."

That it originated in a "freak" seems very likely, since mere cultivation of the familiar white mice (albinos), beloved of children, never develops into a habit of whirling. A German naturalist inbred albino mice for 28 generations without producing any hint of such a peculiarity.

Prevalence of mice. House-mice are very prolific. They will begin to produce young when only three months old, and continue to breed at intervals of two or three months all the year round. It is not known whether any proper pairing takes place-probably not. The period of gestation is 25 days, five to ten young are produced at a birth-minute, pink, blind, hairless things-and are weaned after about two weeks.

There are few houses or barns in which mice do not make themselves at home, racing from cellar to garret in the hollow walls and partitions, and gnawing passageways wherever they think it worth while. Too often they penetrate where food is kept, and besides what 
they eat spoil large quantities by trampling and dragging their tails over or through it, and leaving their acrid-smelling traces. Where they are numerous, this becomes a very serious pest; and it is only the most slovenly housekeepers who will permit their presence. A good cat, kept hungry enough to make her eager to go a-mousing, is probably the best safeguard; but traps are useful-especially the cheap and handy little guillotine traps described in the last chapter. Of course a wise person will stop up all holes, clean out the nests which may be found in an extraordinary variety of snug places, and make the little beasts as unwelcome as possible. They carry fleas and other parasites; and are often sorely afflicted with warbles; but it is not known that they transport the flea which communicates the microbe of the plague. However, their pretty feet often dabble in filth and may bring into the house dangerous germs, so that it is not well to permit them the freedom of your kitchen or pantry.

Mice carrying pathogenic bacilli. In a report of an investigation of the transmission of 
disease by house-mice made by Dr. P. Barabaschi, and published in an Italian medical journal in 1909 (see Experiment Station Record, Vol. XXII, No. 7), it is stated that Dr. Barabaschi has found many bacilli within their bodies and excreta. Among these were the pneumococcus to which croupous pneumonia is due, the bacillus of anthrax, that of erysipelas, those to be found in abcesses, boils, etc., and other pathogenic germs. The mice with the pneumococcus were caught in private houses where there had recently been pneumonia. The excreta of the mice-_"mice dirt", -drying and scattering in dust, may transmit infection even without more direct contact. The greatest danger from this source is incurred by persons working in granaries, etc., where mice abound and their droppings are scattered over the substances handled. It may be added that an American physician asserts that the microbe of measles comes from mice.

In houses left untenanted for a time mice frequently do considerable damage by tearing holes in blankets, bedding and clothing, to get material for their nests. The writer has him- 
self suffered decidedly from their work in a summer bungalow while it was unoccupied during the winter, finding beautiful nests among the bed-clothing, made from his blankets.

Apart from their mischief and dirt, mice are pretty little creatures and make interesting pets for the little folks. Caught young they are easily kept alive and comfortable in a roomy cage and exhibit many interesting ways. Rolled oats are a favorite food, and they like to nibble at grain and at pieces of bone with shreds of meat left on them; they also catch flies and other insects. Mr. Cram is of the opinion that, in cold weather at least, most of the house-mice live almost wholly upon insects, as flies, spiders, wasps and the like, that have packed themselves away snugly for the winter in secret crannies between the boards, sometimes hundreds of them closely huddled together.

Musical mice. One of the most curious and remarkable facts in the history of the housemouse is its so-called singing. Many instances are on record, of which the following related in 
The Scientific American some years ago is typical:

"A few winters since, while one of his family was amusing herself at the piano, a mouse made his appearance on the threshold of the apartment, and, undismayed by the light or the presence of the family, chirped and carolled with intense satisfaction to itself, and to the great delight of its audience. Frequently afterward, but always in the evening, the rare songster repeated his performance. The piano keys were never struck that the mouse did not follow; but when the instrument was not touched, the music from the mouse would come, as if for a reminder. Sometimes the little animal made himself visible and sometimes was hidden in the pantry which, for reasons obvious to housekeepers, he, she, or it had selected as an abode. One evening the mouse was traced to the stairway. Under the carpet sat the little creature, throwing his soul into his song. A lamp was placed beside him, and the family stood and looked and listened for half an hour or more. His head was up, and the movements of the muscles of his throat were plainly visible. Unfortunately our correspondent undertook to capture the singer. Many mice were caught and each was given twenty-four hours grace to sing for its life. But never after the treachery of the trap was the sound of the mouse's carol heard. If caught he died and made no sign." 


\section{THE PANTRY MOUSE}

More lately (1909), a gentleman at Hamilton, Ontario, sent me the following account of a similar case:

"Some months ago in one of the current magazines there appeared an article on "A Singing Mouse." The story related told of a gentleman whose attention was attracted by a peculiar little singing noise, heard in one place, then in another part of his house. Curiosity led him to make a search, which ended, as he told his readers, in the finding in the wood-shed of one or more mice, which, no doubt, were the guilty parties.

"Some few nights ago, in our own house, we heard a peculiar noise. At first we believed it due to some mischievous boys playing the old-time trick of 'Ticka-tack' on the window, as the sound proceeded from that part of the room. The sound resembled it somewhat. The following evening the same sounds proceeded from another part of the house. I was not present, but those who heard it dwelt on the musical quality of the thing, and declared the noise consisted of distinct notes, and ventured to add that it was pretty. Well, we were becoming interested. The third night I was home, and, filled with a bold determination to do or die, went at an investigation.

"The noise proceeded from the kitchen, and one declared it came from beneath the sink. Upon removing a brush in the corner, on the floor, a little mouse ran out. The story in the magazine at once 
came to my mind. I was satisfied as to the 'singing mouse' being a reality.

"The next appearance of our little singer was a night or so after the sink episode, when in the pantry, I and another saw it under a shelf, and it did not show much fear at our presence. It is not unlike other gray mice, only in the song it sings. This evening it was heard in the pantry."

Many other instances might be quoted, some from writings more than a century old. Dr. Elliott Coues wrote an extensive article about these singing mice several years ago in The American Naturalist. His conclusion was that the sound was due to an asthmatic affection of the throat and vocal organs. An interesting narrative of various exhibitions of this faculty is also included in Dr. Merriam's admirable book on the mammals of the Adirondacks (Trans. Linnaean Soc. of N. Y., Vol. II.) ; and in Vol. V. of The American Naturalist, the late Rev. Samuel Lockwood gave a most pleasing history of a white-footed (wild) mouse which was kept in a cage, and was a persistent and prolonged singer, having two or more regular tunes, the music of which he gives. The similar performance of a captive house-mouse is 
related in Vol. V. of The Standard Natural History. All observers speak of the trilling, warbling, bird-like character of the notes.

"It was not much of a song," writes a Detroit lady, "as songs go, but still a distinct musical effort. Sometimes it would run up an octave and end with a decided attempt at a trill. Sometimes it would try to trill all the notes. . . . Its favorite position when singing was an erect one, standing on its hind feet, and holding by its forward ones to the wall or a bracket, almost invariably turning its face towards us. It remained with us several weeks, and at length became so familiar as to appear to enjoy company, seemingly putting forth all its strength to amuse us with its little song, which improved daily in tone and volume, but not in compass. Its voice became so clear that we could frequently hear it in the parlor that opened out of the dining room."

Most persons regard this singing as not due to disease, but quite natural. "There seems good reason for believing," in the language of Ernest Thompson Seton, "that house-mice, and, indeed, all mice, will at times express their sense of well-being in a series of complicated sounds that correspond in every way with the singing of birds." 


\section{CHAPTER III}

\section{THE MEADOW-MOUSE AND ITS MISCHIEF}

WHILE the alien rats and mice are working costly mischief about the house, stable, and granary, their native cousins, the wild mice, are doing vast harm in garden, orchard and field. Naturalists count 200 or more species of these animals in North America, but we need concern ourselves with only certain types, since, from the farmer's point of view, the actions of all are much alike, and the principal damage is caused by those of a single groupthe short-tailed meadow-mice of the genus Microtus. To this genus alone David E. Lantz has devoted a treatise of 64 pages in the publications (Bulletin 31) of the U. S. Biological Survey from which, as before, I shall quote freely. He prefaces this treatise with the statement that the mice of this genus alone cause an average annual damage to American farmers of not less than $\$ 3,000,000$. It is this 


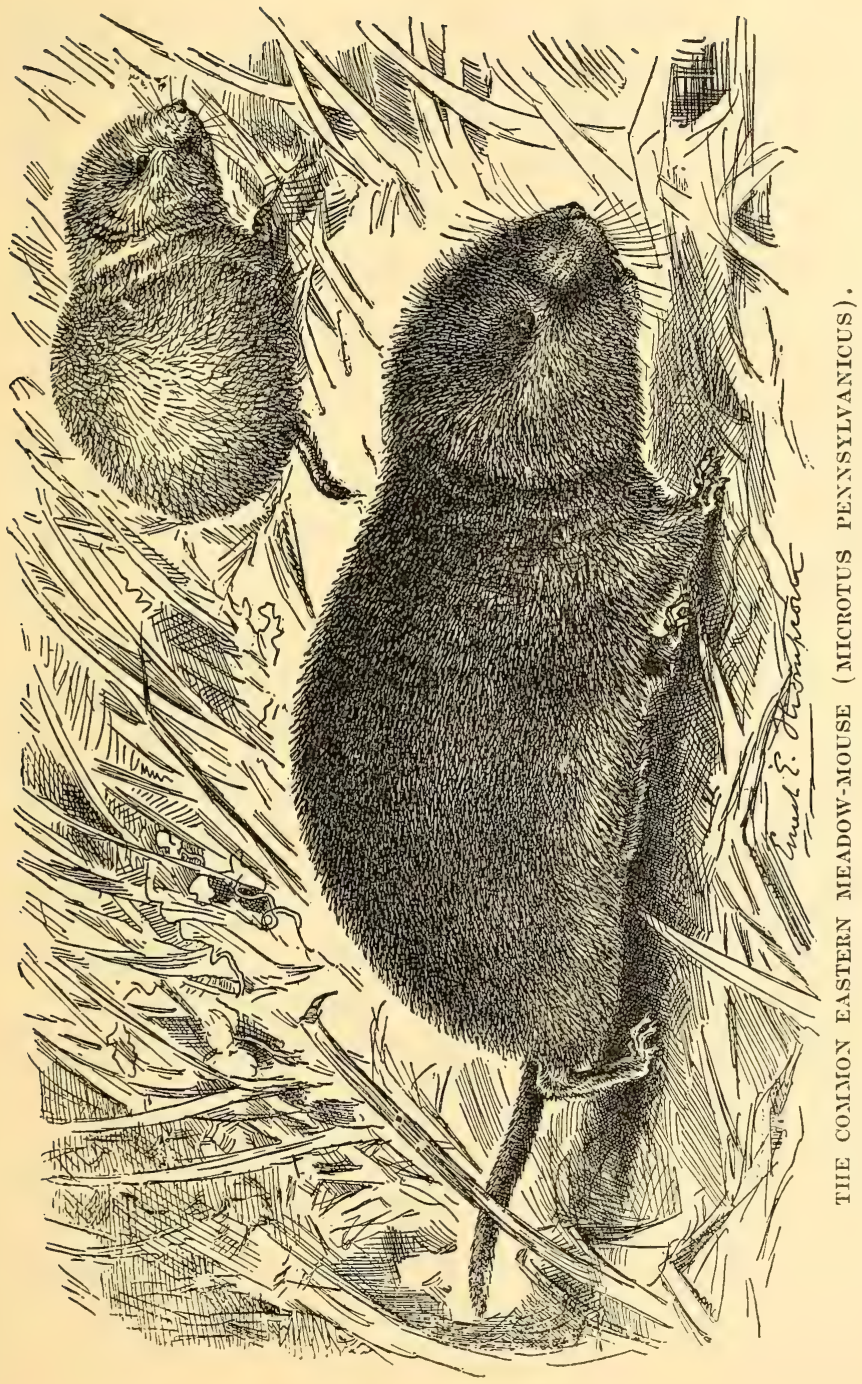


kind of mouse which now and then in this country, and still more frequently in eastern Europe, appears suddenly in such vast numbers as to constitute a veritable plague, ruining the produce of the year in all directions.

Sometimes wild animals increase in numbers so suddenly that the change has been likened to a tidal wave, and ignorant people have regarded the invasion as of miraculous origin. The belief that crickets, locusts, frogs, and even mice sometimes fall from the cloudș is still held in many countries.

"The careful observer, however, sees little mystery in the phenomena mentioned. He has studied the general habits of animals-their food, their powers of reproduction, their migrations, the checks on their increase due to natural enemies, disease, and varying climate-and consequently he attributes sudden changes in their numbers to known causes. In such changes he recognizes, especially, the influence of man, both direct and indirect, and his responsibility for interferences that greatly modify the operations of nature."

American voles or meadow-mice. The mice of the genus Microtus (formerly Arvicola) represent a group which embraces a large number 
of forms of small and very similar rodents which in some respects resemble true mice, but are readily distinguished by the robust body, thick head, very short ears, blunt muzzle and short, hairy tail.

There seems to be no entirely appropriate vernacular name for these mice. The French call them campagnols, the Germans wühlmäuse. English-speaking people outside the United States call them voles. In the United States they are variously designated as meadow-mice or field-mice, and locally as bear-mice, bullmice, buck-tailed mice, mole-mice, and so forth. Meadow-mice would do very well if it were not that several of our four-score species belong to the high dry plains of the West. As, however, the typical meadow-mouse of the east ranges over nearly the whole country, its name may well be adopted for the whole genus.

The three species most frequently met with in connection with damage are:

1. Common meadow-mouse (Microtus pennsylvanicus.)

2. Prairie-mouse (M. ochrogaster.)

3. Pine-mouse ( $M$. pinetorum.) 
The common meadow-mouse (No. 1) is $61 / 2$ inches long, of which the tail takes $13 / 4$ inches; and has eight teats. Its fur is long, overlain with coarse black hairs, and in winter almost conceals the ears. The usual color above is a dark brown, against which the black hairs are not conspicuous. This shades off gradually into gray or tawny on the under parts. This species may be said to inhabit the whole continent, though in the mountainous parts of the West other species are more numerous and conspicuous.

This mouse has its natural habitat in moist meadows and grassy borders of swamps, but it habitually extends its range into neighboring cultivated fields and waste lands. Nearly all meadows are full of the animals. On parting the thick grass almost anywhere one can find the smooth trails, and where the grass is thin they are often plainly visible. After the melting of deep snow, or where the dry grass has been. burned, the network of runways is especially conspicuous to the eye. In swamps the path.s* cross soft mud, and where a green scum of minute floating plants covers stagnant 
water, the trails are often defined across it by streaks where the animals swim from side to side.

The normal number of young averages about six, brought forth in an underground burrow.

Prairie and pine mice. The prairie-mouse (No. 2) differs only slightly from No. 1. It is a little smaller, the rough tail is shorter, its two colors are more sharply contrasted, and the general pelage coarser. The color of the under parts shades into a buff or cinnamon, and in winter becomes gray. It is confined to the central Mississippi valley, where is produced more than half the corn, oats and winter wheat of the country; and two closely related species extend the range of mischief to the dry plains west and northwest. These prairie-mice have an especially fine opportunity for damage, and in the winter are more destructive to trees than the $M$. pennsylvanicus. Fortunately, therefore, they are less productive, having usually only three or four young at a time, and the long summer droughts and extreme winters of the interior West further limit reproduction.

The typical pine mouse or red-backed mouse 
(No. 3) is found only in the Carolinas and Georgia, but several varieties widen the specific range from southern New York to Oklahoma, south of the latitude of Lake Erie. The typical Georgian pine mouse has glossy, mole-like fur of a bright russet-brown color. The variety of the blue-grass region is darker and very glossy, while that of the states west of the Mississippi, between southern Iowa and northern Texas, is deep chestnut. In all, the skull is wide and flat, and the fur short, dense and glossy.

Owing to their peculiar habits, pine mice are not so well known as are the northern meadowmice. Their natural habitat is the forest, although they are by no means restricted to pinewoods or forested areas. The life of the pine mice is largely spent in underground tunnels, which so closely resemble those of the mole that generally they are mistaken for the work of that animal; but the inner diameter of the mouse-tunnels is less. When moles and pine mice live in the same vicinity, the mice often use the runways made by the former and this habit has helped to bring moles into disrepute with farmers. 
From their intricate tunnels under the leafmold frequent burrows descend into the soil, some of which are utilized as nesting places. Nests are built also at the surface of the ground, under fallen logs, brush-heaps, flat stones, fences, or other shelter. The number of young at a birth evidently averages less than is usual in the genus Microtus, as is shown by the small number of mammæ; but this is counterbalanced by the safer underground existence; so that within their range pine mice are about as abundant as other field-mice.

Quick and Butler, writing of the food-habits of the pine mouse in Indiana, state that it lives upon the tender roots of young hickories, the young sprouts of white clover, the fruit of the red haw, and the tuberous roots of the wild violet. These writers found all but the fruit buried, some in deposits of a gallon in a burrow, and the caches sometimes extending 18 inches below the surface of the ground. Violet roots predominated in these stores. Kennicott also states that pine mice store acorns and nuts in burrows for winter use.

Living in concealment neither their presence 
nor the injury they inflict is suspected. Bulbs planted hopefully in autumn, appear not at all in spring, or only in the shape of sickly plants. Nursery and orchard trees fail without reason until their roots are examined and the work of this hidden nibbler is disclosed.

General wild habits. It appears then that in habits there is considerable variety among the mice of this group (Microtine), but least in the matter of diet. While some species have a vastly widespread range, others are confined to very limited localities. Some species prefer high and dry ground, while others live in low, moist places. Except in cold weather, nearly all species can temporarily adapt themselves to moist surroundings; but a few seem to be almost as aquatic as the nearly-allied muskrat. Some dwell in forests, others in the open prairies; some burrow under the ground like moles, while others make smooth paths or trails upon its surface.

The nests of meadow-mice are compact bunches or globes, composed chiefly of grass blades and other dry vegetable fibers. They are placed in depressions in the ground, in 
shallow burrows, or supported on grass stems or brush-piles above the ground. Sometimes they are placed under flat stones or logs or under shocks of grain. The structures are so slight that a day's sunshine will dry them out after a storm, and yet they are so compact that the animals pass the coldest weather snugly housed in them under the snow. The young of most kinds are born in underground nests and are at first hairless and blind. When discovered in the nest the mother vole slips noiselessly away, sometimes carrying the young attached to her mammæ.

The breeding-season includes most months of the year, except mid-winter in cold latitudes and periods of long-continued drought. The number of litters in a year thus depends on climate, and especially upon the character and length of the winter. In temperate latitudes in normal seasons from four to six litters are produced; but the variation in the same species is remarkable, and depends partly upon climate, but probably more on the scarcity or abundance of food. The period of gestation is about twenty days. 
These mice, like their European relatives, the voles and lemmings, at times increase in number's abnormally, but the causes are little understood. At such times they multiply with amazing rapidity, and begin breeding when only six months old.

"If a thousand pairs of field-mice," remarks Mr. Lantz, "survive the winter in any neighborhood, the potential conditions for a vole plague are present. If, now, instead of normal reproduction, circumstances bring about a considerable increase both in the number of young at a time and in the number of litters in a season, the probability of a plague is greatly increased."

Plagues of field-mice. Swarms of mice devastating the fields have been seen by very few American farmers, though occasional severe outbreaks of this kind are on record in Nova Scotia and in various eastern states. They have been all too frequent in all parts of the Old World from the earliest times, and used to be regarded superstitiously as punishments sent from on high. The valley of the Danube and the plains of southern Russia seem to have 


\section{MISCHIEF OF MEADON-MOUSE}

been especially subject to these devastations, which have ocenred most terribly eren within the past few years.

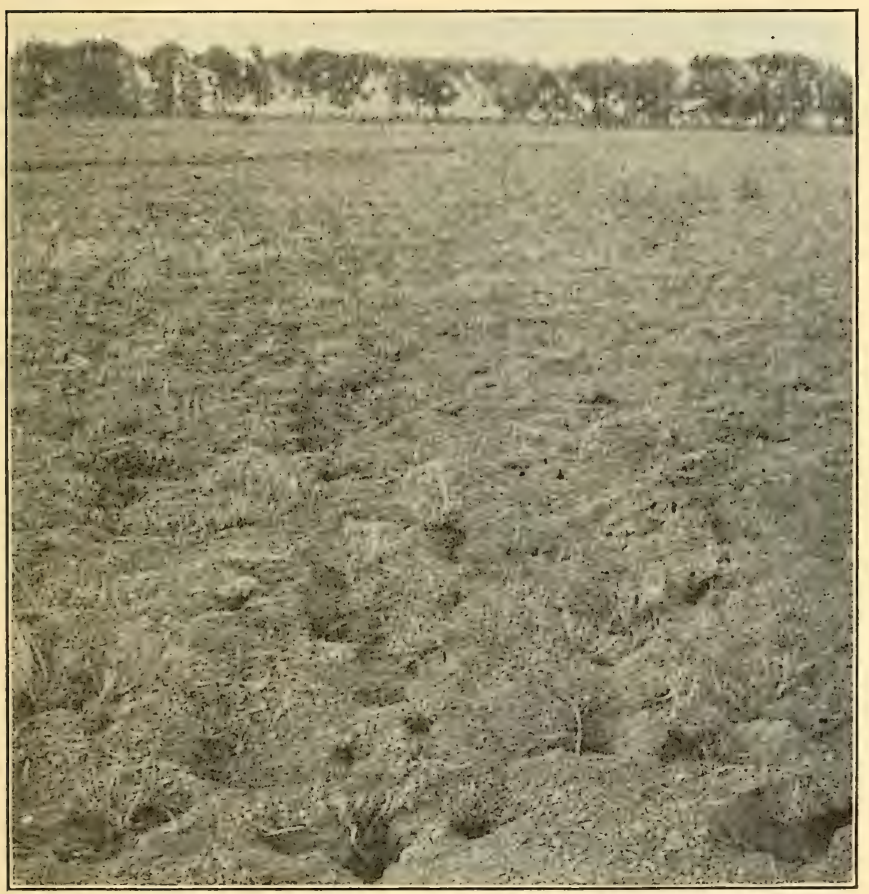

AN ALFALFA FIELD DEVOURED AND HONEYCOMBED BY FIELD-MICE.

In 1907-8 an outbreak of field-mice in Nevada, Utah and northeast California, threat- 
ened to develop into a plague as great as any recorded, and the facts concerning it have been studied and preserved in a pamphlet by Stanley E. Piper of the Biological Survey. The species was the black or Carson mouse (Microtus montanus), which is widely prevalent west of the Rocky Mountains.

"The greatest loss occurred in the rich fields of alfalfa bordering Humboldt River for the last ten or twelve miles of its course. Noticeable here through gradually increasing damage during 1906, the fieldmice appeared early in the summer of 1907 in alarming numbers. By November they had overrun a large part of the cultivated area, and on many large ranches were estimated to number from 8,000 to 12,000 to the acre. Fields were literally honeycombed by their holes, which numbered about 24,000 to the acre. During the summer they ruined onethird of the alfalfa, destroyed three-fourths of the potatoes, and severely injured root-crops, as beets and carrots. Upon the disappearance of green food in the fall they attacked the roots of alfalfa, so as to render many alfalfa fields a total loss. They girdled and killed most of the young shade-trees planted along ditches and about the borders of fields, while small orchards suffered severely."

Decline of the visitation. By January, 1908, the ravages had extended over considerably 
more of the district, and the main body of mice was gradually progressing to fresh fields. From this time, however, the abatement of the plague was rapid. By March 15, the invasion of fresh lands had ceased, though mice continued considerably in excess of normal abundance until May. By August they had practically disappeared from the valley. This scourge left a dismal scene of destruction over four-fifths of the cultivated area in the district. Of 20,000 acres in alfalfa, 15,000 were so completely destroyed as to require replanting. Considering the actual losses in crops and the cost of restoring the alfalfa fields, and allowing for the value of the wheat which replaced alfalfa in most of the ruined fields for the season of 1908 , Mr. Piper estimates the loss in this district at $\$ 250,000$.

Some interesting particulars are recorded as to the diminution of the horde, which was preyed upon by a gathered crowd of predatory birds, mammals and reptiles, as well as extensively poisoned, yet succumbed at last mainly to natural mortality, - not to any specific bacterial disease. 
"In the spring," Mr. Piper relates, "the mice in this locality failed to reproduce, while the same species was breeding prolifically in other localities. In March several hundred females were examined in Humboldt Valley, of which very few were pregnant. Moreover, the mice themselves presented a different appearance from those seen when the plague was at its height-a fact noted by many ranchmen in the valley. During the fall of 1907 larger and much more vigorous individuals predominated, while in the spring of 1908 scarcely any of these remained. They continued in destructive numbers until . . . May. But they did not noticeably breed with the return of favorable weather and by August had practically disappeared."

Prevention of plagues of mice. Unfortunately the liability to such "plagues" increases with the spread of settlement and cultivation. "Agricultural development distinctly increases the danger by furthering the destruction of their natural enemies, by furnishing a great abundance of food, and by increasing the area in which they find favorable homes." On the other hand, the prevention of plagues is comparatively easy. Systematic poisoning must be relied upon to repress them when they are obviously on the increase, but 


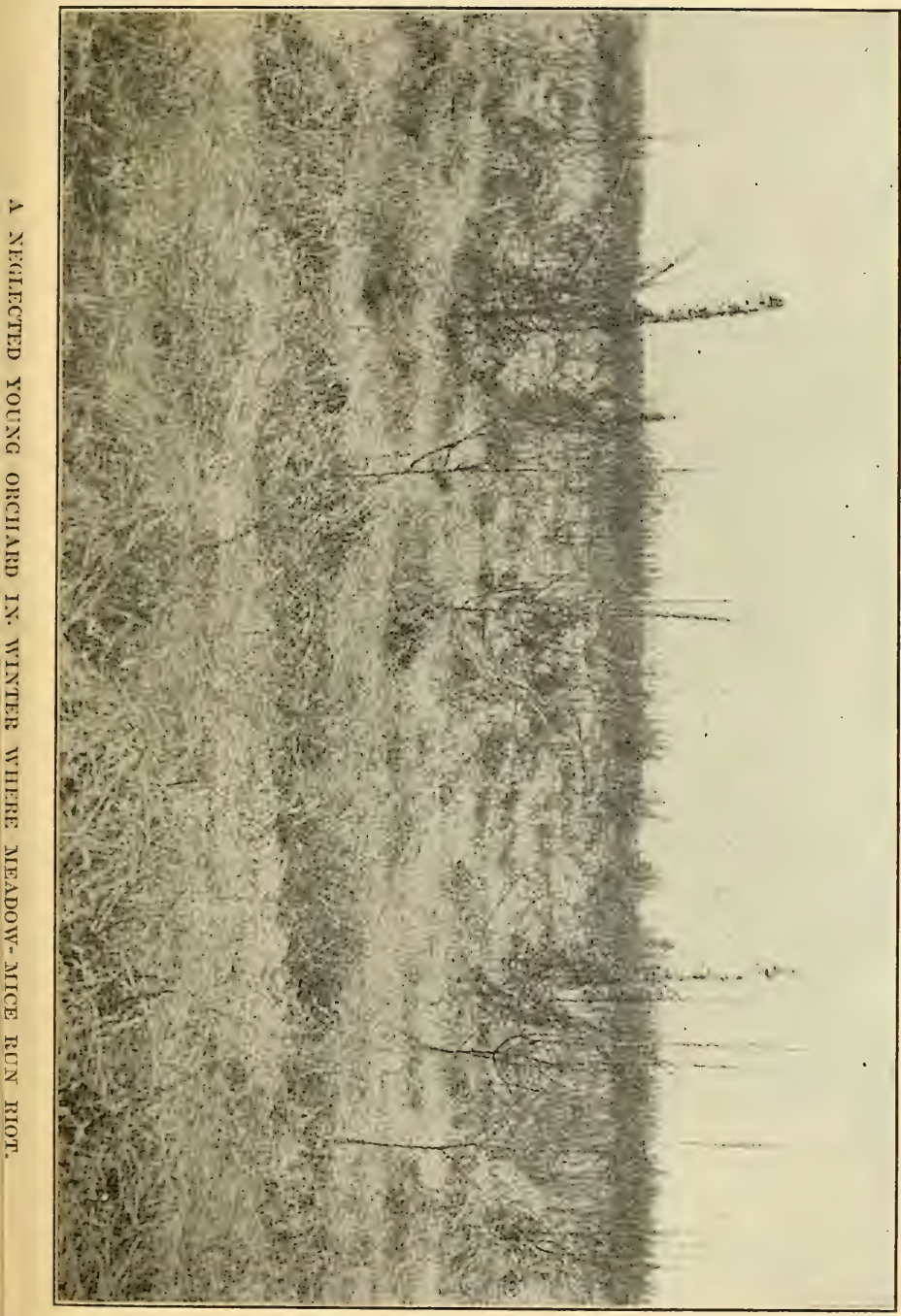

(i.) 
there are many inexpensive methods for preventing this increase. The destruction of rank grasses and weeds along fences and ditches, and particularly, in the West, the pasturing off of the last growth of alfalfa in fall, thus exposing the mice to the sight of predaceous enemies, are important. Winter-burning of dry vegetation on wild hay lands, on strips bordering fields, and on swampy or otherwise waste areas in and about cultivated fields, will aid materially in controlling them. The survivors may invade cultivated fields, but there they can be more readily poisoned. Flooding the fields in cold winter weather, when the mice quickly perish from exposure, is an effective method in irrigated lands. Plows turn out the burrows and nests of practically all the mice present and render them easy victims for dogs, which when trained to kill mice can not be too highly recommended as effective and inexpensive aids in controlling the pests. That hawks, owls, gulls, crows, ravens, and herons among birds, and skunks, weasels, foxes, and badgers among mammals, are persistent enemies of field-mice and other rodent pests has been often 
pointed out. The protection and encouragement of these valuable allies of the farmer can not be too strongly advocated.

Trapping, systematically continued, is of great service; and advice upon it is given at the end of this book, as also for poisoning these small pests.

Food of wild mice. Returning now to a further consideration of the mice in the normal numbers which are always with us, an understanding of their feeding is most important as a preliminary to repressive measures.

In summer the principal food is green vegetation and unripe seeds of grain and grasses. As the season advances, ripe grain and seeds take the place of the immature; and in winter bulbous and other roots are in part substituted for stems and leaves. It is mainly in winter that apple orchards and young forest trees suffer, for meadow-mice invade cleanly cultivated fields only under shelter of snow. Unlike the foreign voles, our American species do not, as a rule, lay up winter-stores in any considerable quantities, as do some other American micethe deer-mice, for instance. Instead, our mead- 
ow-mice are active all winter-not hibernating, but gathering food from day to day and wandering widely. Yet in the far North the climate has compelled habits of winter provision in the tundra vole (Microtus operarius) which is small, inhabits the mossy tundras of western Alaska, and gathers stores of small bulbous roots, sometimes placing a peck or more in a single cavity just below the surface on a mossy knoll or slope. In autumn, shortly before the first snowfall, the Eskimo women and children discover these stores by means of pointed sticks. In this way considerable quantities of food are gathered, which are boiled and eaten as a delicacy. "The boiled roots have a flavor like a boiled unripe sweet potato, and are very palatable during the long winter fare of meat and fish," according to E. W. Nelson.

Damage from murine voracity. Complaints of damage to meadows and pastures have been steadily increasing, with occasional reports of the total ruin of a red-clover field. More grass is cut down and left than is eaten. In winter, haystacks are attacked and sometimes so riddled as to be spoiled for market. 
Growing grain of all kinds is destroyed.

Field-mice injure early peas and other vegetables, and pine mice often destroy potatoes in the ground. In the fall vegetables piled on the ground or stored in pits are liable to attack, and especially celery. Apples, pears, and other fruits are eaten also, including melons.

Blackberries, raspberries, grapes, currants, gooseberries, and strawberries are often badly damaged by field-mice, and when the animals are abundant whole plantations are ruined. Strawberries are especially liable to injury because of winter mulching and also because the plants themselves furnish excellent food and shelter for the animals. Winter mulching of small fruits increases the damage unless carefully guarded by clean surrounding areas.

Damage to standing nursery stock is done usually under cover of snow; and in addition to girdling trees above the surface meadowmice sometimes dig down and attack the roots. Pine mice usually begin their evil work with the sprouting grain, and, in the case of fallsown wheat and rye, continue it during the entire winter. Much greater damage is done 
when the grain is nearly mature, as stalks are then cut down; and after harvest the animals attack the shocked grain. In shocks and stacks the mice are perfectly at home, and multiply with such rapidity that within a few weeks a pair and their progeny may totally ruin an entire shock of wheat, oats or corn. In view of this situation it is a question whether the farmer who hastens to market his crop is not, on the whole, a gainer over his neighbor who waits for more favorable prices.

In these and other ways the annual destruction of grain and forage throughout the country is enormous; nor is the injury all done by the short-tailed meadow-mice. Deermice (Peromyscus), pocket-mice (Perognathus), harvest-mice (Reithrodontomys), and ordinary house-mice are also concerned in the damage. Throughout the country the brown rat and in the Southwest the cotton-rat (Sigmodon) are serious field-pests.

General preventive measures. The foregoing testimony sufficiently shows the noxious character of these small rodents; and suggests the query: "How shall it be stopped?" 


\section{MISCHIEF OF MEADOW-MOUSE}

In view of their wide distribution, the nature of their habits and the abundance of shelter and food everywhere in America, it is impossible to get rid of them; but it is not hopeless to reduce their ability for damage to a negligible quantity. Thorough and clean cultivation, with frequent plowing, is perhaps the most effective general remedy, and where this is done throughout a group of adjoining farms, and the roadside weeds and fence-tangles are regularly cut, or burned over, little trouble will be experienced within the district.

Next to this is the preservation of the birds and other animals which prey upon mice, and which have been so ruthlessly killed off in most rural districts, partly through the insane tendency to kill every living thing which animates many country boys and men, and partly through mistaken ideas as to the harm such animals do. Even persons who ought to know better engage in this miscellaneous destruction of the best friends a farmer can have,-proof of which will appear later in this book.

"One of the most common mistakes made by sportsmen in the supposed interests of game protection," 
remarks D. E. Lantz, "is the offer of prizes for the destruction of alleged 'game-destroying' mammals and birds. In one instance nine competitors for a club's prizes destroyed during twelve months 184 weasels, 48 foxes, 54 minks, 343 skunks, 15 great horned owls, 6 'common owls,' and 148 hawks. The fact that only 21 owls were killed in an entire year by nine men trying for a record reveals a scarcity of these useful birds that is not complimentary to the intelligence of the community. The large number of skunks killed indicates ignorance or disregard of the usefulness of that animal in destroying insects and mice. Apparently, too, there was no discrimination as to the species of hawks destroyed, and it is probably safe to say that field-mice in a single year have damaged the farmers of the region concerned a hundredfold more than the value of all the game and poultry saved through the offer of prizes."

Protection of orchards and nurseries. Injury to orchards and nurseries by field-mice may generally be prevented by forethought and the exercise of ordinary care. Of first importance, always, is clean tillage. No grass or weeds should be left in or near the nursery. So well is this understood by the majority of experienced nurserymen that by clean tillage they secure practical immunity from the ravages of mice except in winters of deep and long- 


\section{MISCHIEF OF MEADOW-MOUSE 71}

lying snow. Unfortunately, nurserymen can not control the lands which environ their trees, and when snow falls to a considerable depth prompt measures are sometimes necessary to keep mice from destroying them.

This can be accomplished most readily by dragging a heavy log several times around each block of trees, packing the snow so firmly that mice cannot tunnel under it. If this be done promptly after the first snowfall, subsequent falls will require little attention. Under no circumstances should matted grass or litter be allowed around the trunks of trees or along the borders of the orchard. In the absence of snow a cleared space of about 18 inches radius about each trunk is enough to prevent damage. This space should be as smooth and clean as possible.

Tree-protectors and washes considered. If any part of the orchard is so located as to be subject to snowdrifts, and mice are abundant in the vicinity, tree-protectors should be used. These may be had of dealers for 60 to 75 cents per hundred, or they may be made by the farmer. Strips of wire cloth make excellent 
protectors, and tarred paper is a favorite with some horticulturists. The wire cloth or paper'

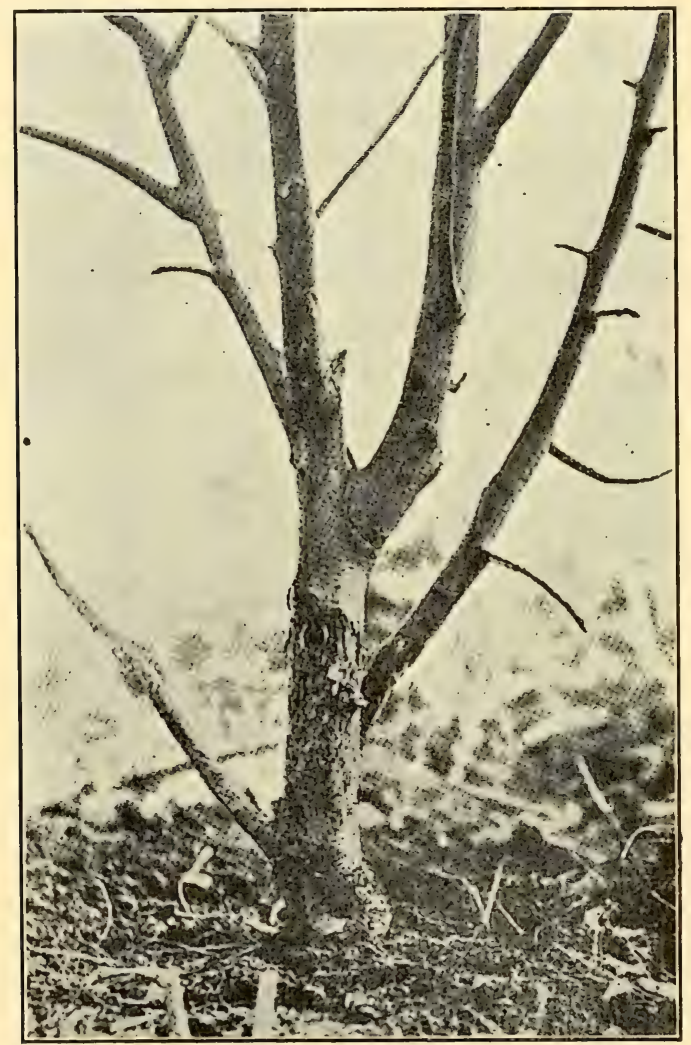

AN APPLE-TREE GNAWED BY MEADOW-MICE.

is cut into strips about 7 inches wide and at least 15 inches long. A strip is secured around 
each tree with wire or cord. Tarred paper should never be used on very young trees, and when used on others should not be left in place during the summer, since it may injure the growing tree.

Various paints and washes have been recommended to prevent attacks of mice and rabbits in orchards. The majority of these are without merit and some of them are liable to kill young trees. Some of the washes require renewal after every hard rain. In experiments with a wash of whale-oil soap, crude carbolic acid, and water, for apple trees, it was found that in about forty-eight hours the carbolic acid had so far evaporated that mice renewed their work upon the bark. Blood and grease, said to give immunity from rabbit attacks, would invite the attention of field-mice.

Reports recently received by the Biological Survey seem to indicate that the ordinary limeand-sulphur wash, recommended for the winter spraying of trees to destroy the San Jose scale, is an effective preventive of the attacks of both mice and rabbits. The wash is very cheap (from 1 to 2 cents a gallon when prepared in 
45 to 50 gallon quantities) and is easily applied to the trunks of trees either in the form of a spray or by the use of a brush. One thorough application in November would probably be effective for the entire winter. The ingredients of the wash are 20 pounds of unslaked lime, 15 pounds flowers of sulphur, and water to make 45 to 50 gallons. The mixture should be boiled in an iron kettle at least an hour and applied to the trees while warm.

Winter mulching of trees is dangerous, unless the neighborhood is known to be free from mice. Mulch containing straw may be placed in the orchard in spring, but it should be removed before the approach of cold weather. Fine, thoroughly rotted manure may be used in the orchard with but little danger. Lime or ashes about the trunks of trees has some value in keeping off mice, but clean cultivation is equally or more effective.

Remedies for injured trees. When trees are girdled by mice, portions of the inner bark (cambium layer) are often left, partly covering the hard wood below. If sunlight and wind have free access to the injury, the remaining 
bark dries up and the tree dies. If light and air are excluded, new bark will form and the wound quickly heal over. To facilitate the healing process, it is important that wounds be covered as soon as possible. All that is needed is to mound up the soil about the trunk of the tree high enough to cover the wound, and the covering should remain all summer.

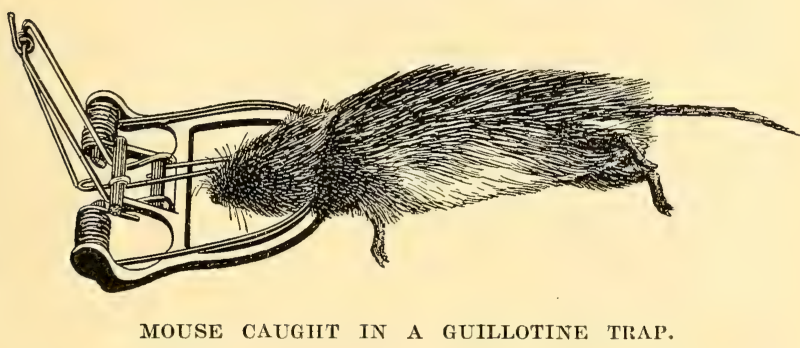

This is the simplest, cheapest, most humane, and on the whole most effective trap for catching and killing rats, wild mice or house-mice. 


\section{CHAPTER IV \\ PROFIT FROM THE MUSKRAT}

In Europe some of the best-known species of meadow-mouse are large and aquatic, as, for example, the common water-rat of England. Of the same sort, on a larger scale, is our American muskrat-a huge, water-dwelling vole with a tail compressed into a sculling-oar, whose appearance and manner of life are familiar to most of us.

Mischief done by muskrats. In the Eastern States muskrats do little damage, although everywhere abundant, except occasionally by opening a dike that protects a New England salt-meadow from high tides. West of the Alleghanies, however, they often cause great annoyance to the owners of canals and reservoirs by their burrowing; and frequently enter gardens near the water-side and devour fruit and vegetables to a considerable extent, while cornfields sometimes suffer much when the corn 
is in the roasting-ear stage. At times, also, they have ruined ornamental ponds by eating out of them the lilies and similar plants of whose bulbs they are fond. But this sort of destruction is rarely noticed except in the neighborhood of extensive marshes.

Far more serious, however, is the trouble and loss the busy animals occasion by perforating the dams and embankments of mill-ponds, ice-ponds, irrigation ditches and reservoirs. Every canal suffers breaks due to them, as well as to brown rats, gophers, mice, crayfish and moles. In the rice plantations of the Gulf coast they are a serious nuisance by cutting the embankments and flooding or draining the ricefields at the wrong time; and this has resulted in Louisiana in laws protecting the alligators in some parishes because they kill the rats. So serious was the situation in Plaquemine Parish, La., in 1908-9, that a general slaughter of muskrats took place, and fully half a million are said to have been killed. The sale of their pelts produced about $\$ 100,000$.

Trapping, shooting and poisoning may all be made effective to a certain extent against 
muskrats, but should only be employed in exceptional circumstances. The most valuable works open to their attacks should be constructed of or faced with rubble or concrete to a proper depth.

Muskrats worth far more than the damage they do. As a matter of fact the harm done by muskrats is, on the whole, far outbalanced by their value in fur, so that in Canada, and in many states of the Union, the animal is protected during a close season (April to November), when its young are being nurtured and the fur is not "prime," i. e., in good condition for market. These states are Delaware, Illinois, Iowa, Maine, Maryland (coast counties), Michigan, Minnesota, New Jersey, New York, North Carolina (coast counties), South Dakota, Virginia (coast counties) and Wisconsin. This protection, however, ends too early in the fall. The open season should not begin in the United States before December 15, and should close by March 15; in Canada it may be slightly prolonged.

The muskrat supplies one of the most useful and dependable sources of fur for clothing, and 


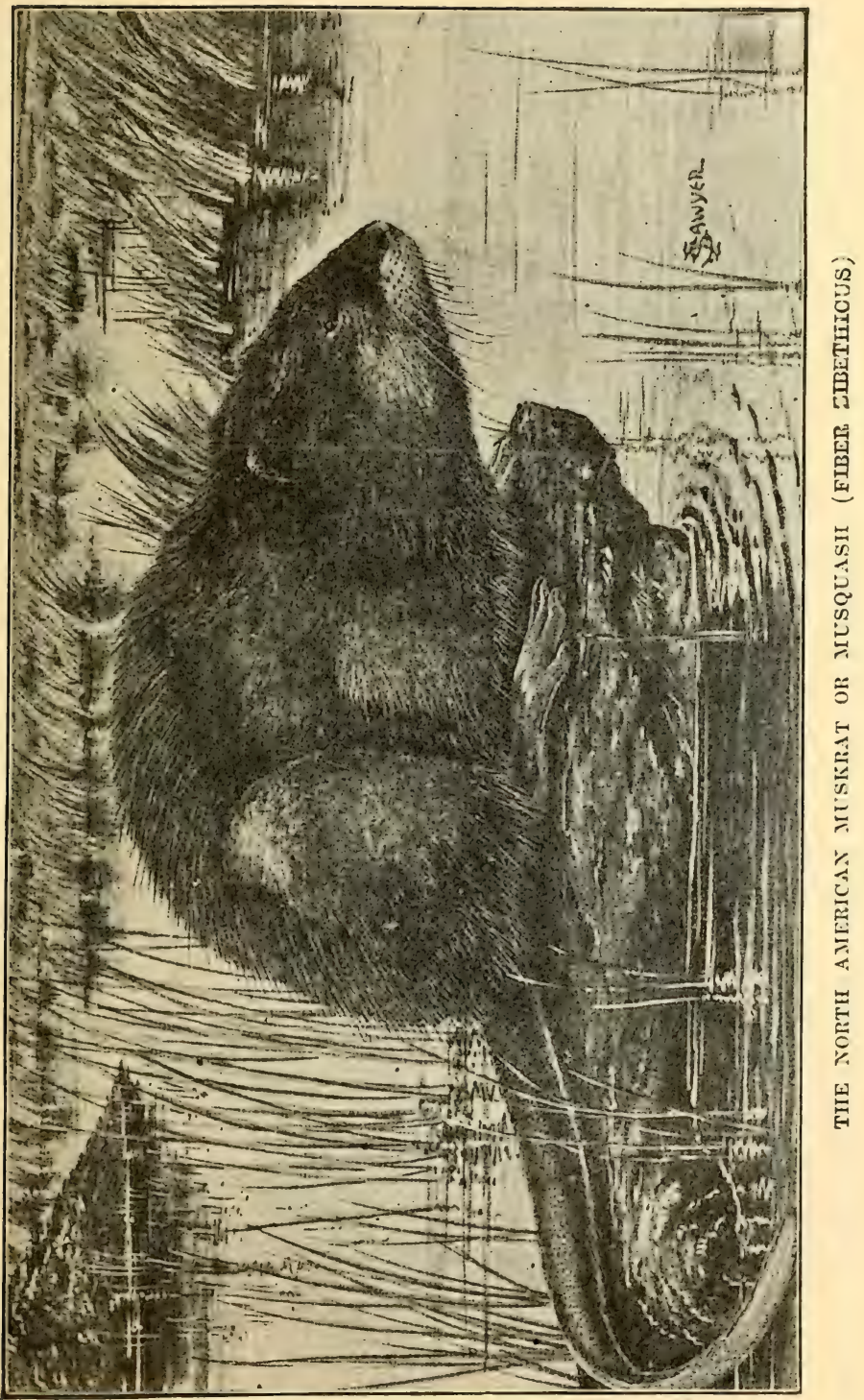


also a good flesh-food which is not utilized to the extent it deserves.

Excellence of muskrat flesh. The Indian aborigines habitually ate this flesh, especially in winter, and taught the colonists how to cook it, boiled with corn, into a toothsome dish. The early western hunters and explorers were glad to get it, liking it roasted over a slow fire. Lantz tells us that in the retail markets of Philadelphia, Baltimore, Wilmington and other cities, these animals are sold as "marsh rabbits," but no attempt is made to conceal the fact that they are muskrats.

"They are bought and eaten both by well-to-do citizens and by the poorer people who seldom indulge in high-priced game. The animals are trapped primarily for their pelts, but after they are skinned, the additional labor of preparing the meat for market is so slight that they can be sold very cheaply.

"In the Baltimore markets, February 21, 1908, I found muskrats for sale at various stalls. The retail price was 10 cents each. At the commission houses I learned that several firms receive them regularly from the lower Chesapeake.

"In February, 1907, the Philadelphia Record stated that a single dealer on Dock street in that city sold about 3,000 muskrats a week for food. The chief 
source of this supply was stated to be in the vicinity of Salem, N. J. The Saginaw (Mich.) Courier-Herald states that in the season of 1907-8 dressed muskrats at that place retailed at from 15 to 20 cents each, and that dealers had ready sale for all they could provide. Muskrat is said to be a favorite dish at dinners given by church societies in Delaware and Maryland, and annual muskrat banquets are a feature with certain gun clubs in the West. Those of the Monroe (Mich.) Marsh Club have been celebrated for many years. Nearly a dozen years ago, when the club desired the enactment of a law to protect the muskrat on the marshes adjoining the Great Lakes, they went to Lansing, taking with them their own chefs, and invited the entire Legislature to partake of their hospitality. . . . The law was passed without opposition.

"The flesh of the muskrat is dark red in color, but fine-grained and tender. Unfavorable opinions as to its flavor arise, probably, from lack of skill in cooking or from carelessness in skinning the animal. In the usual method of skinning, the hair-side of the pelts does not come in contact with the flesh, the musk-glands often come off with the skin, and only in summer does the musky odor pervade the flesh. An unskilled person is more likely to leave some of the odor, but in winter it may all be removed by washing [as, also, the gamey flavor, when too strong for one's taste, by soaking in salt water.] The novice should be careful to keep the fur from touching the flesh, to avoid cutting into the musk-glands, and to 
trim off any subcutaneous glands that may adhere to the meat."

The following published recipes for cooking muskrat are credited to George T. Bowen, a caterer of Baltimore, Md.

"Fried Muskrat.-Wash the meat thoroughly and eut in quarters. Let it lie in salt water for an hour or more, then wash, dry with a eloth, and season. Dip the pieces in a prepared egg-batter and dust them with flour or meal. Place the lard in a frying-pan and let it get hot. Then put in the muskrat and fry very slowly for an hour. Prepare a gravy of milk, butter, flour, and parsley, and season it to taste. After it thickens pour it over the cooked muskrat.

"Roast Muskrat.-Wash the meat thoroughly, let it lie for an hour or more in salt water, and then wash again. Put it in a pan with water, salt, pepper, butter, and a little onion; sprinkle flour over it, and baste it until it is thoroughly done.

"Stewed Muskrat.-Wash the meat thoroughly, cut it in pieces, and let it lie in salt water for an hour. Then wash again, put it in a saucepan, and seas?n with butter, salt, and pepper to taste. Let it simmer slowly, and when nearly done put parsley and a little chopped onion into it. When entirely dore thicken with a gravy of flour and water, as for stered chicken."

Steady demand for muskrat fur. It is, however, for its pelt that the muskrat is chiefly 
valued, and should be preserved and cultivated under properly restrictive conditions. Compared with most other furs of small size, muskrat furs are of excellent quality and durability; their cheapness is chiefly the result of their abundance. Properly dyed and made up, they are difficult to distinguish from sealskin, but their wearing qualities are greatly inferior. The modern dresser and dyer have found means of imitating nearly all the more costly furs with that of this animal, and have thus created a continuous demand for the pelts.

Notwithstanding that during the past 150 years nearly 250 millions of muskrats have been trapped, vast numbers of these pelts reach market annually. The sales at the great London auctions (which determine prices for the world) for 1909 were 3,771,000, at higher prices than at any time previously. Many fur-buying establishments advertise most alluringly, in order to induce consignments from local dealers, or from individual trappers; but in many cases they grade the furs so low that the returns are far below expectation. It is probably better policy, as a rule, for the amateur 
rural trapper to sell his pelts to a local buyer whom he knows and trusts than to ship them to a distant dealer. In any event he ought to understand the points of quality by which his furs are graded, and keep himself informed as to current prices.

Trapping the muskrat. Muskrats are not suspicious and are easily trapped. They take any suitable bait readily, especially in winter and early spring, when green food is scarce. A strong steel trap breaks the leg bone and in struggling the animal is apt to tear loose, leaving a foot, or part of it, in the trap. For this reason the traps should be set so that the captives will quickly drown. The best baits are carrots, sweet apples, parsnips, turnips, or pieces of squash. Many trappers use scent to attract the animals, but the practice is of doubtful utility.

Most muskrat trappers use the ordinary steel trap (No. 1). The manner of setting it depends upon the situation, and the skill of the trapper is best displayed in selecting this. Muskrat trails may be found along the banks of all streams and ponds which they inhabit, and the 


\section{PROFIT FROM THE MUSKRAT 85}

practiced eye can often trace them into shallow water. Sink the trap in the trail, partly in the mud or sand where the water is two or three inches deep, and fasten the chain to a stake, or, better still, to a slender pole, reaching into deep water. Fasten the bait to a stick set in the mud, so that the bait is about a foot above the pan of the trap. The animal in reaching for the bait sets the hind foot upon the pan and is caught more securely than if taken by the fore foot. It immediately plunges into deep water, sliding the chain along the pole as far as it will go, and soon drowns. If the chain is fastened to a stake, it should be planted in water a foot or more in depth, so that the animal will drown.

Besides this water-set for the steel trap, other situations will suggest themselves to the intelligent trapper. One of the best is in the opening of the animal's burrow in the bank. Here no bait is required. Sometimes a spade is needed to cut out a piece of turf and make room for the trap, the top of which should be at least two inches under water.

When ponds are frozen over, traps are often set in the muskrat houses, the trapper going 
to them on the ice; but this practice destroys the houses and is not to be commended. Trapping near the houses in open water is far better. When the houses are not far from the bank, a long plank may be used advantageously as a support for traps. It is moored to the shore by a wire passed through a staple driven into one end of the plank, while the other end projects into the pond or rests against the side of the muskrat house. Light cleats are nailed to the upper side of the plank at intervals of a foot with space enough between them to hold a trap when set. The ring at the end of each trap chain is fastened to the plank by a staple. Baits of carrot or apple may be scattered along the plank; but they are not necessary, since the animals will use such a plank as a highway to the shore, and are almost sure to be caught. Most of the occupants of a house may sometimes be taken on one plank in a single night.

"The box trap is a favorite with some trappers. They use a long wooden box whose cross section inside is about 6 by 6 inches and which has a gate at each end. The gates are of wire and arranged to swing inward but not outward. The box is set just under water with one end at the entrance to a muskrat burrow. 
The animal lifts the gate on leaving the burrow and is imprisoned and drowned. Others follow until perhaps all the occupants of the burrow are caught. A similar trap may be made entirely of heavy wire netting of half-inch mesh, bent to shape. These traps are well adapted to very narrow streams or ditchesfavorite runways of the animals.

"An open barrel sunk near the bank of the stream or pond frequented by muskrats is said to be an effective trap. The top of the barrel should be level with the surface of the ground. The barrel is half full of water, upon which pieces of carrot or apple are floating. A piece of board about 8 inches square, or a few floating chips, will delude the animals into jumping into the barrel to secure the food. Muskrats taken alive should be killed by a sharp blow across the back of the head.

"A floating barrel is said to be a good substitute for a sunken barrel. A hole 8 to 12 inches square is sawed in the side of a barrel having both ends intact. A strong cleat is nailed across each end, projecting 6 or 8 inches on the sides. Upon the projecting cleats boards as long or somewhat longer than the barrel are nailed. Enough water is placed in the barrel to make it float with the outer platform level with the surface of the pond-say, with about one-third of the surface of the barrel exposea.

"Another way of taking the muskrat is to spear" it inside its winter house. This is a common Indian method; but it should not be encouraged. Not only are the pelts injured by the spear, but when the 
ponds are ice-bound, the animals that escape the spear often perish after their houses are destroyed."

Trapping was at one time a popular calling in the United States; but fur-bearing animals have so decreased in numbers that nowadays few persons earn a livelihood by trapping alone. A large part of the supply of muskrat fur is taken by boys, who adopt this method of earning a little extra spending money. They often attend school, and look after the traps in the morning and evening.

Preparation of the pelt. Muskrat skins intended for market should be "cased," not opened along the belly. In skinning begin at the heel and slit up the middle of one hind leg to the tail, around it, and then down the other leg to the heel. The skin may then be easily (but gently) turned back over the body, leaving the fur side inward. Next, cut closely and cautiously around ears, nose and lips, and scrape off adhering bits of flesh. The skin, inside out, is then stretched over a thin board shaped like a rifle-cartridge, and a tack or two is inserted to keep it in position until dry,the drying should be in the open air, not before 
a fire or in the sun, and not exposed to rain. Formerly many of these skins were dressed at home, but the process is complicated and difficult.

Cultivation of muskrats. In view of the real value, continuous demand, growing difficulty of obtaining prime pelts and consequent steady enhancement of price, it has occurred to many persons that the rearing of muskrats in protected marshes and under favoring conditions would be profitable. Some of the experiments already tried in this direction have succeeded well, but they are in reality little more than a coöperative protection of certain extensive haunts against over-trapping as well as against poaching. Large tracts of marshes at the western end of Lake Erie, controlled by sporting clubs, are thus governed and yield a substantial revenue under wise management.

In this way a new value has been given to extensive areas of marsh, liable to tidal overflow, along the western margin of Chesapeake Bay, where landowners now lease the trapping privilege, and trappers and owners unite to protect the marshes from poaching. The owner 
receives half the fur caught, while the trapper gets the other half and all he can realize from the sale of the meat. In the short season of seventy-four days, January 1 to March 15, during 1908 and 1909, trappers easily made from $\$ 400$ to $\$ 900$ each.

The demand for the meat is growing, and all of it is utilized. The Baltimore market takes about 30,000 animals during a season, the bulk of which come from Dorchester County, Va.

The editor of the Cambridge Record, a local newspaper, stated (1909) that the muskrat industry of Dorchester brings into the county about $\$ 100,000$ annually. This would indicate that about a quarter-million of the animals are trapped each season. The danger of exhausting the supply by continued close trapping has been discussed in Dorchester County, but trappers there maintain that with the long closed season, March 15 to January 1, little ground for anxiety on this score exists. However, it is worth keeping in mind.

Possibilities of this business. There are many places in all the eastern half of the United States where a similar industry might 
be developed, even though on a smaller scale; and it is a very suitable investment and occupation for men and boys who might organize small local companies to carry it on effectively. As it is winter work, little time useful for anything else would be needed. The chief requirements are protection for the animals during a close season, and from poaching in winter; and a suitable limitation of the number taken, based upon local circumstances.

In their natural haunts no feeding is required; and it may often be advisable in places to enlarge the area suitable to the animals by damming the outlet so as to flood a wider area. The rats increase rapidly when encouraged, though the varying testimony on the subject seems to show that they differ in this respect in different parts of the country. Seton says that in Manitoba there are commonly said to be three litters a year, of four to nine each, and that the first litter of the year themselves have young in the autumn. The period of gestation is about 30 days.

Suitable places and proper care. There are few swamps and marshy streams in which 
these rodents are not naturally numerous, and they persist in the midst of civilized districts in a marvelous way. There would seem to be no difficulty then in colonizing a new artificial marsh or pond for the sake of rearing them. Such a place, however, must have a natural or planted growth of suitable food-plants-lilies, arums, sedges, etc.-whose roots form their winter subsistence. Among the principal of these plants are yellow and white pond-lilies, the golden clubhead or river-bulrush, a large sedge whose fleshy tubers are nutritious, and the lotus (Nelumbo). In summer they feed upon a far more extensive list of aquatic plants and shore grasses, vegetables and fruits, and also largely on mussels, snails, crayfish, caddisworms, sluggish fish, like carp, and now and then catch ducks and other small animals. The feeding-habits of the wild muskrats of the locality should be carefully considered.

The highest usefulness of a "muskrat-farm" would be gained, however, by improving the stock in size and color. To do this selective breeding should be attempted. The larger and blacker the pelt the higher price it will bring. 


\section{PROFIT FROM THE MUSKRAT 93}

It would be well, then, to trap as many of the year's crop as possible alive, and to put back any notably large or very black ones to act as breeders, while the small and light-colored examples were steadily weeded out. In this way only a few years would be required, in a restricted community, to produce a notable improvement in your muskrats.

As little expense or trouble is required, muskrat-farming ought to be a very profitable enterprise in many places. 


\section{CHAPTER V}

\section{CAN THE BEAVER BE SAVED?}

Here, too, may be considered the beaver, with reference to the possibility of preserving it from extinction, and cultivating it for fur. In most of our states and provinces this animal is more or less under legal protection, and scattered colonies flourish throughout the mountainous parts of the West, while several zoölogical parks and some private estates have colonies. These thrive, and increase so fast that from time to time it is necessary to thin out the band. A newspaper reports that about 100 were in this way culled out of the colony in Algonkin Park, a national reserve in northern Ontario, during 1909.

It would seem entirely feasible, then, for anyone having a favorable place on his estate to rear beavers. A swampy valley is usually of little usefulness otherwise. The cost of confining and protecting the colony would, how- 


\section{CAN THE BEAVER BE SAVEI)? 95}

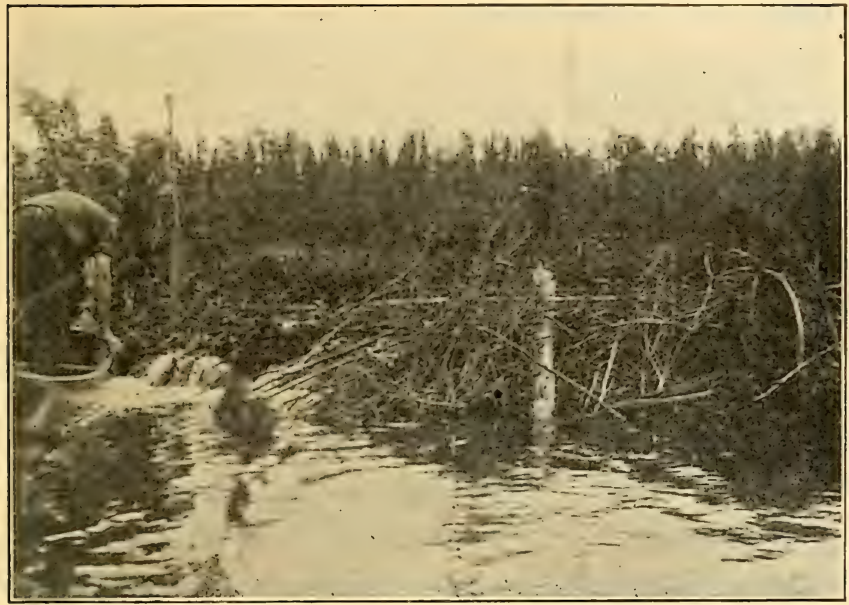

A BEAVER-DAM NEAR LAKE TEMISCAMING, ONTARIO.

From a Photograph by George S. Bryan.

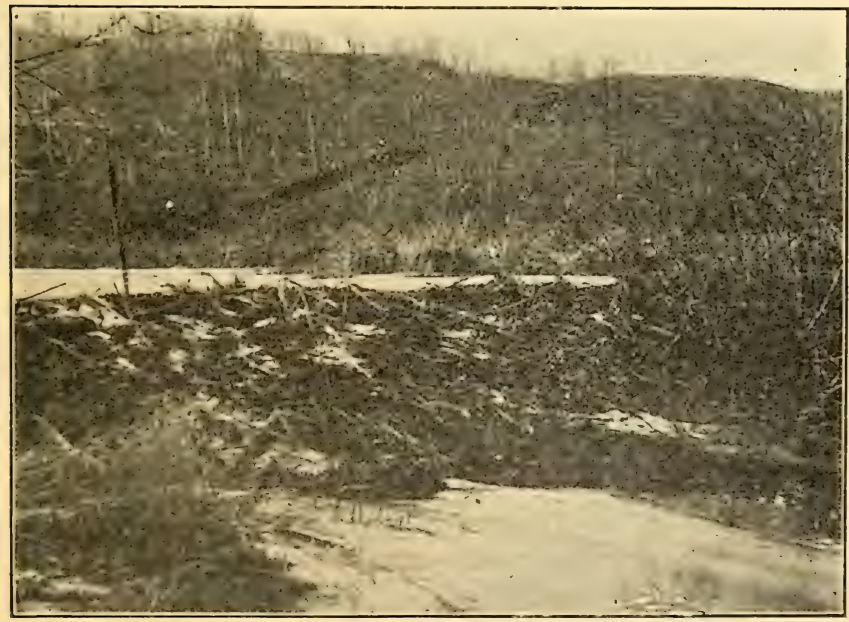

A BEAVER-DATL ON THE UPPER SASIATCHEWAN 
ever, be considerable in most situations. A strong iron or wire fence which would resist their jaws, and which would also keep out bad dogs, would be a large item if it enclosed an area spacious enough for extensive operations. Only a short time would elapse before the beavers had cut down and used up all the trees and bushes which were not jacketed with stout wire higher than they could reach; and after that it would be needful to feed them with fresh tree-limbs of suitable kinds. Lastly, if the colony amounted to anything it would doubtless be necessary in most places to guard it well against human marauders who would kill the animals for their valuable pelts. It is to be noted that these animals will not eat the bark of evergreen (coniferous) trees of any kind.

It is proper also to add a caution quoted from Vernon Bailey's notes on Texas mammals (N. A. Fauna, No. 25.)

"In talking with John Seavel, an old beaver trapper, I asked him why it would not pay to protect the beaver in a pond like that above Pecos bridge (over the Rio Grande), and let them multiply. The idea was not new to him, for he had talked it over with other trappers and all agreed that it was not worth 
trying because they considered the beaver naturally ferocious, to a great extent solitary and a slow breeder. Seavel says that two old beavers rarely live together in one house or even in one small pond; that they fight and chase away any neweomers; that if a family grows up and is undisturbed in a pond or a deep bend of the river, its members keep all others of the species away, and that they attack and kill any one of their number that is found in a trap or sick or crippled. While he thinks that systematic breeding for fur is out of the question, he admits that the beaver should be protected all over the country until the few that remain increase and restock the streams."

If this is generally true, it may be found that the most profitable course for a beaver-cultivator is to acquire control of a stream already tenanted by beaver, and guard them there in their natural life, taking only a proper proportion each year. 


\section{CHAPTER VI}

\section{WOOD-RATS, PACK-RATS, COTTON- RATS, ETC.}

IN the South and West are to be found a great number of species of rodents called woodrats (Neotoma) which are pretty, interesting and amusing rather than harmful in their magpie-like mischief. They are rat-like in form, with long, scantily-haired tails, but squirrel-like in agility and climbing power; and more inclined to go abroad in the dusk of evening and morning than during the brighter hours of the day.

Florida and Texas species. One species is well known in wooded country from New Jersey southward, and is 13 inches long, including a 5-inch tail, brownish gray, the sides tawny, the belly and feet all white. Bartram described the animal and its home, as he met with them in Florida almost 150 years ago.

"They are singular," he says, "with respect to their ingenuity and great labor in the construction 98 
of their habitations, which are conical pyramids about three feet high, constructed with dry branches, which they collect with great labor and perseverance, and pile up without any apparent order; yet they are so interwoven with one another, that it would take a bear or wildeat some time to pull one of these castles to pieces."

"The very playful character of this species," remarked Audubon, "its cleanly habits, its mild, prominent and bright eyes; together with its fine form and easy susceptibility of domestication, would render it a far more interesting pet than many others."

West and southwest of the Plains live many closely related species, some of which inhabit the mountains, others only timbered valleys, while still others are restricted to desert valleys. All erect more or less elaborate and often conspicuous houses, sometimes in the branches of trees-a safer place than on the ground.

Vernon Bailey discusses upon them thus:

"For houses they heap up a bushel or more of sticks, stones, cow-chips, cactus, bones, or other materials which the animals can earry and pile up as a protecting cover for their nests and burrows in the ground beneath. Cactus and thorny branches, if available, are always a conspicuous part of the building material. The house is usually occupied by one old rat, a pair, or 


\section{$100 \quad$ ANIMAL COMPETITORS}

a family, but never by a colony. Wood-rats are social and visit back and forth from one house to another until well-worn trails often connect the houses and lead to the feeding grounds. The food of these animals is mainly seeds, berries, and many kinds of green foliage. Where the houses are located near the edges of fields, grain, fruits, and vegetables are sometimes

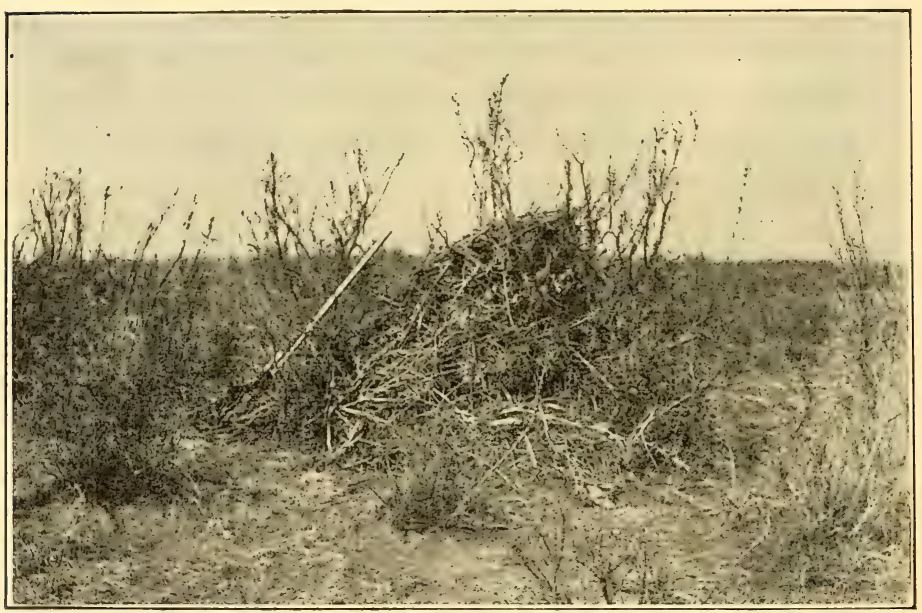

FIELD-NEST OF BAILEY'S WOOD-RAT.

From Warren's "Mammals of Colorado." By Permission of G. P. Putnam's Sons. Photo by H. W. Nash.

eaten or carried away and stored up for food, but fortunately the rats are never sufficiently numerous to do serious damage. Their houses are easily destroyed and the oceupants captured by a few minutes' work with a shovel, or the rats can readily be trapped or poisoned. They frequently enter cabins 
WOOD-RATS, PACK-RATS, ETC. 101

or camps not permanently occupied and eat or carry away provisions. They sometimes cause great annoyance by cutting leather harnesses or saddles. There is rarely more than one animal responsible for the mischief in a camp, however, and a rat-trap will usually prevent further trouble. It is unfortunate that the odious name of rat has become attached to these bright and interesting little animals, as otherwise they might become a table delicacy. They are cleanly in habits and are strictly vegetarian in diet. Their flesh is as white and delicate as that of the quail and finer in flavor than that of the squirrel or rabbit.",

The mountain pack-rat. The best-known of these wood-rats is that yellowish-gray one of the Rocky Mountain region, with the very bushy tail, known as pack-rat, trade-rat or bush-rat (Neotoma cinerea), and its reputation is an evil one. As Warren remarks: "While the warm weather lasts (in Colorado), they do not trouble habitations very much, but when in the mountains the weather begins to get colder the rat looks out for a warm place for his winter residence, and often selects the miner's cabin or some ranch-house.' It soon makes its presence known by carrying away any portable articles, and it makes no difference 
whether they are of any use to the animal $\mathrm{or}^{\circ}$ not. It has been known to carry off even sticks of dynamite.

Its nests are frequently lined by shredding gunny-sacking or clothing. Rolled or folded blankets have been completely riddled by them in their search for stuff to make their beds, which often are placed in queer situations. A correspondent in British Columbia tells of one which inhabited a letter-box nailed against a tree in a lonely locality.

"I visited him often," he writes, "and on opening the door, his head, with its big round eyes and great round ears, would appear out of his warm bed with an expression of inquiry, but with no sign of fear. He had brought everything in through a knot hole, apparently too small to admit even his body. Before his nest was stored a pile of Oregon grapes and green leaves, but I could not discover that he ate any of them, although occupying the box for some weeks."

On the Pacific coast they are fond of establishing themselves in the sod roofs of log cabins -or used to be, when such structures were more common than nowadays-and become a nuisance.

A capable thief. The following account, 
WOOD-RATS, PACK-RATS, ETC. 103

communicated in 1877 to The American Journal of Science by A. W. Chase, shows what the animal is capable of in the way of mischief. The tale relates to a dwelling-house near a disused sawmill in Oregon:

"This house was left uninhabited for two years, and, being at some distance from the little settlement, it was frequently broken into by tramps who sought a shelter for the night. When I entered this house I was astonished to see an immense rat's nest on the empty stove. On examining this nest, which was about five feet in height, and occupied the whole top of the stove (a large range), I found the outside to be composed entirely of spikes, all laid with symmetry, so as to present the points of the nails outward. In the center of this mass was the nest, composed of finely divided fibers of the hemp packing. Interlaced with the spikes we found the following: About three dozen knives, forks and spoons, all the butcher knives, three in number, a large carving knife, fork and steel, several large plugs of tobacco; the outer casing of a silver watch was disposed in one part of the pile, the glass of the same watch in another, and the works in still another; an old purse containing some silver, matches and tobacco; nearly all the small tools from the tool closets, among them several large augers. Altogether it was a very curious mixture of different articles, all of which must have been transported some distance, as they were originally stored in different parts of the house. 


\section{ANTMIT COMPETITORS}

"The ingenuity and skill displayed in the eonstruce fion of this mest, and the rurbus taste for artirles of iron, many of them heavy, for component parts, strurk me with smrprise. The articles of value were,

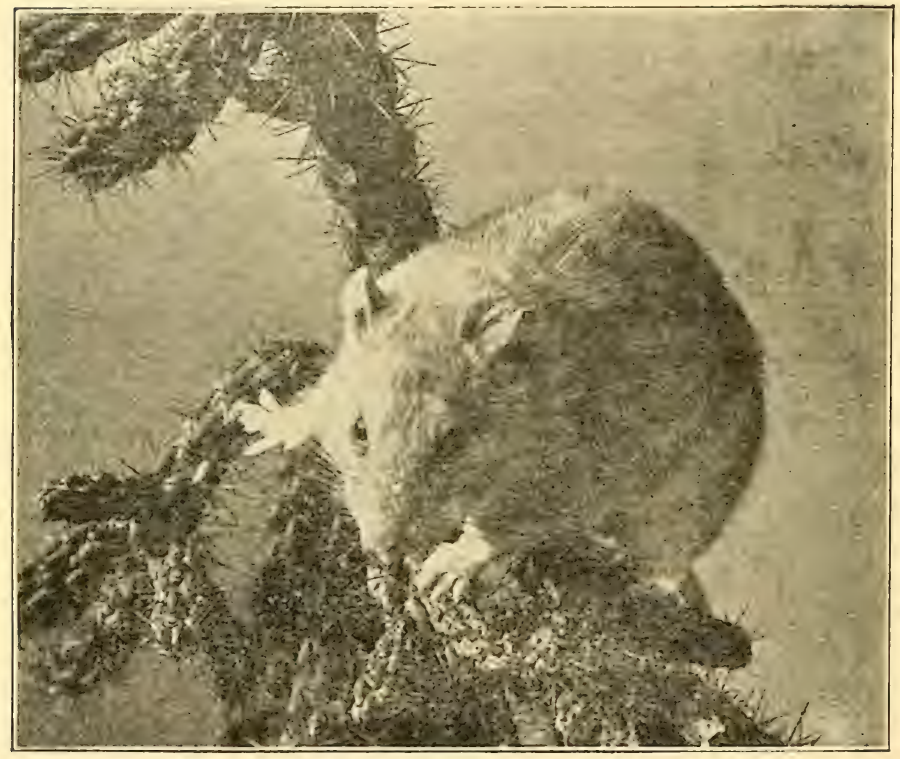

A ROCKY-MOUNTAIN PACK-RAT.

From Warren's "Mammals of Colorado." By Permission of G. P. Putnam's Sons. Photo by H. W. Nash.

I think, stolen from the men who had broken into the honse for temporary lodging. I have preserved a skctch of this iron-clad nest, which I thiuk unique in natural hiștory.

"Many curious facts have since been related to me 


\section{WOOD-RATS, PACK-RATS, ETC. 105}

concerning the habits of this little creature. A miner told me the following: He once, during the mining excitement in Siskiyou County, became, in California parlance, 'dead broke,' and applied for and obtained employment in a mining camp, where the owner's hands and all slept in the same cabin. Shortly after his arrival small articles commenced to disappear; if a whole plug of tobacco were left on the table it would be gone in the morning. Finally a bag, containing one hundred dollars or more in gold dust, was taken from a small table at the head of a bunk in which one of the proprietors of the claim slept. Suspicion fell on the newcomer, and he would perhaps have fared hardly, for with those rough miners punishment is short and sharp; but just in time a large rat's nest was discovered in the garret of the cabin, and in it was found the missing money, as well as the? tobacco and other articles supposed to have been stolen.,"

The destructive cotton-rat. It would be possible to write extensively, and perhaps entertainingly of a long list of other wild mice and rats, such as our very pretty, white-footed wood-mouse (Peromyscus) which, in its various species and subspecies, is scattered all over the continent; but few of them have sufficient economic interest to justify it. There are times when any or all may become dangerous by 
overmultiplication; but the only sort now of importance in that direction is the southern cotton-rat (genus Sigmodon.) The common species ( $S$. hispidum) is typically a denizen of the Atlantic coast from North Carolina to Florida, but its varieties extend the specific range westward to Mexico. The total length is $10-10 \frac{1}{2}$ inches, two-fifths of which belongs to the tail. The color varies a good deal, but in general is a yellowish grizzle above, and ashy to whitish below.

Their natural habits much resemble those of their neighbors, the pine mice, and like them they have not only surface runways but long galleries and nesting-places under the soil. They may be very numerous without attracting much attention because of this cryptic manner of life, and still more because they rarely come abroad until after dark. There have been times, as in 1889 in western-central Texas, when they swarmed in a regular "plague," and played havoc with the corn-crop. They are especially numerous, always, along the borders of cotton-fields, and Bailey records that in Texas their runways are often fairly lined with 
WOOD-RATS, PACK-RATS, ETC. 107

cotton that has been pulled from the bolls and dragged under cover where its seeds can be eaten with safety, while a small amount is carried away for bedding. Considering the great area of the cotton-growing country, all infested with these busy pilferers, the aggregate loss of cotton must represent a large sum.

"A simple and effective remedy," as Bailey reminds the planter, "would be to clean out the borders of fields by burning the weeds, grass and rubbish accumulating along the fences year after year as a harbor for various rodent and insect pests and a perennial source of supply for weed-seeds. If these borders were burned yearly, mowed and raked, treated with oil or chemicals to prevent weed-growth; closely pastured or thoroughly cultivated, the hawks and owls would quickly dispose of the rodents which would then have no protecting cover.'

Jumping-mice,-Allied to the true or murine mice, and even more nearly to the Old World jerboas, are the jumping-mice, pocket-mice and kangaroo-rats of the family $Z$ apodide,-all interesting and beautiful little animals but not requiring much attention here, because their 
presence affects humanity in a very trifling degree.

The only representative in the East is the common tawny-red, large-eared jumping-mouse, often seen rushing away from under foot in amazing leaps. The hind legs and feet are tremendously developed, while the fore pair are exceedingly small and delicate. The nose is pointed, and the hairless tail very long, measuring 5 inches from root to tip, while the length of the body is only 3 inches. They subsist almost exclusively on weed-seeds, and go early to bed in warm grass-nests underground, where they remain in deep hibernation until late in the spring.

In the arid West and in Mexico live numerous small cousins of the genus Perognathus, whose hind legs are less lengthened, and which have fur-lined pockets in their cheeks, tiny ears, gray or yellowish coats, pure white feet and under parts, and tails about the length of their bodies. They are rarely seen, because nocturnal; burrow in dry ground; and lay up stores of small seeds. They are easily caught in small traps baited with rolled oats (of which 


\section{WOOD-RATS, PACK-RATS, ETC. 109}

all mice are extremely fond); and "unless as the result of a great reduction of mouse-hunting birds and mammals, they will never be a pest.' They are styled kangaroo-mice, or elfmice.

Western kangaroo-rats. A third group is that of the kangaroo-rats, found in all the arid valleys west of the Plains and south of northern Idaho and the Sacramento river. While not even remotely related to either kangaroos or rats, they have been thus named on account of their long hind legs and tails, small hands, and their method of progressing by hops. One species, the desert kangaroo-rat, (Dipodomys) is distinguished by its large size, about twice that of the others (Perodipus).

This large four-toed kangaroo-rat of the Great Basin and southern California is the one of most interest. It is about 5 inches from tip of nose to base of tail, and the tail is about 8 inches long. Its legs and hind feet are disproportionately long, in striking contrast to the tiny front feet, or hands. The large head, prominent black eyes, and short ears give the animal a quaint appearance. The glossy coat 
is light sand-color over the upper parts and pure white below. The tail is white along the sides and for an inch at the tip. The fur-lined cheek-pouches are large enough to admit the tip of the little finger.

These, and the smaller kangaroo-rats, are common over the drier parts of the valley country, especially in the mellowest and sandiest soil; and Ernest Thompson Seton has made them the subject of one of his most accurate and charming descriptions of animal life. They are strictly nocturnal and are rarely seen alive, but their round burrows are conspicuous, and the paired tracks of their long hind feet may be seen every morning on the naked sands. The manner of traveling is by hops, or long leaps on the hind feet, while the tail serves as a balance and rudder, the tiny front paws being used only as hands. The burrows usually. enter the side of a sandy hillock, dune, or embankment, and often extend 10 or 20 feet. They do not go deep into the ground, but if started at the base of an embankment they may penetrate through it below the water-level and tap the ditches,-mischief wholly accidental. Usually 
WOOD-RATS, PACK-RATS, ETC. 111

on entering the burrow before daylight in the morning they securely close the opening behind them by packing it full of fresh sand, doubtless to keep out snakes, weasels, and other unwelcome intruders.

Their food consists mainly of the small seeds of native desert plants, but also includes a little grain. A part of the food is carried into their burrows for future use. They are never sufficiently abundant to seriously injure crops, but a year or two ago were found damaging vineyards in the Santa Cruz Mountains, California, by biting off fruit-buds. The trouble was easily disposed of by scattering poisoned grain near their burrows. This course will always free a locality from them whenever they may become a little harmful. 


\section{CHAPTER VII \\ THE GRAY GOPHERS}

THis brings us to another group of burrowing and pouched rodents, which, however, are far from harmless-the gophers. This term is given in the Gulf States to a burrowing turtle, and in the Northwest to a striped groundsquirrel, but those here in view are the chunked, short-legged, blunt-nosed, short-tailed grounddiggers of the family Geomyide.

They inhabit nearly the whole of the open country west of the Mississippi river not lifted into mountain ranges, and one species, locally called salamander (Geomys tuza), occupies large areas in Florida, Georgia, and Alabama. The western plains are the home of two prominent species, the dark "common" one (Geomys bursarius), formerly spread as far east of the Mississippi as the prairies extended and now dwelling between that river and the Rocky Mountains from near the Canadian line to the 


\section{THE GRAY GOPHERS}

Gulf coast; the yellower, larger, chestnutfaced gopher (Cratogeomys castanops), occurring from Colorado southwestward; and the

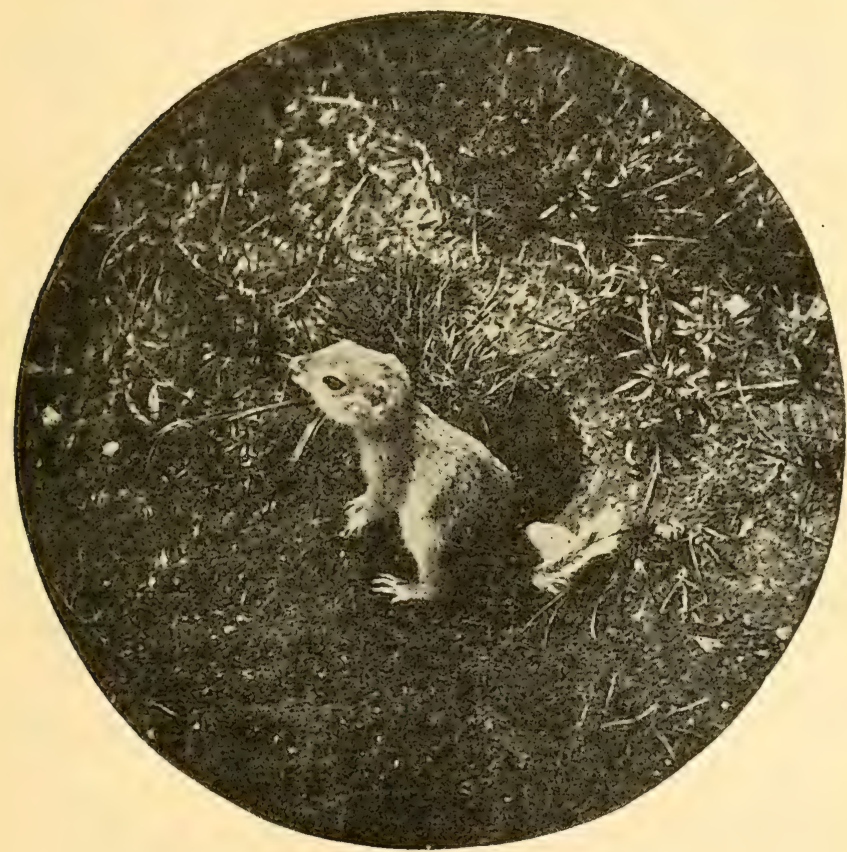

NORTHERN GRAY GOPHER (THOMOMYS TALPOIDES).

Photographed by H. K. Job, and reproduced by permission.

smaller noithern gray gopher, or mole-gopher (Thomomys talpoides), which is the familiar of the Dakotas, Wyoming and the Cana- 
dian plains. West of the Rockies occur a large number of species, some very difficult to distinguish from one another, of which the reddish Thomomys douglasi of the Columbia River valley, and T. botte (chestnut above, reddish brown below) of central and southern California, are most notable. In many regions they have increased rather than diminished with civilization, owing to the destruction of their natural enemies, to the loosening of the soil by plowing and to the vast increase of food afforded them by orchards, gardens and crops. Though several genera and species are separated by zoölogists, from the farmer's point of view there is a substantial likeness, not only in their yellowish-gray or brownish, unmarked coats; their big, thick heads; their short strong legs; their almost invisible ears and eyes; the massive incisors and capacious furry cheekpouches, opening outside the mouth;-but in the constant and fearful damage they work in the field, orchard and nursery.

Burrowing powers. The pocket-gopher digs as long as he lives, and generally all winter, for he does not hibernate, even at the coldest. All 


\section{THE GRAY GOPHERS}

his life is passed underground, except when for an instant he emerges into the air to push a load of earth from a freshly opened hole. Except for one month of the year, the mating season, all pocket-gophers live an entirely solitary life; and like most other hermits, they are of an extremely surly disposition. They will fight viciously on all occasions, and they have formidable weapons.

In tunneling in the earth, they use their long and powerful front teeth as a pick to loosen the ground. At the same time the forefeet, which are armed with long curved claws, - the sides of the toes being lined in turn with bristles which prevent the dirt from passing between them,-are hard at work both in digging and in pressing the dirt back under the body. There the hind feet take it and push it farther back.

When earth enough has been accumulated behind the gopher, he whirls about, and by bringing his wrists together under the chin, with the palms of the hands held vertically, he pushes the earth out in front. He will move backward as rapidly as forward, and can push dirt either 
way. His movement in digging often seems as rapid and automatic as that of a shuttle.

Except in times of deep frost, the burrows are seldom more than a foot underground, and generally about six inches. At intervals, often within a few feet, the gopher comes to the surface to throw up a little hill of dirt; but the opening which he makes is closed by being

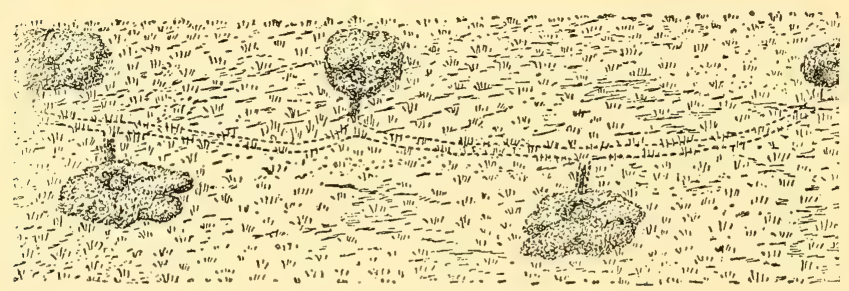

DIAGRAM OF A GOPHER'S BURROWING.

packed so full of dirt that no trace of the tunnel is visible except the little mound.

The gopher goes on digging in winter as well as in summer; but if the frost prevents him from coming to the surface, he uses a cross section of his tunnel into which to pack the earth which he has dug for his new excavations. These tightly packed cylinders of earth are often turned up by the plow.

Pocket-gophers apparently breed only once a 
year, in the spring, when two to six young are produced in a litter in some roomy central chamber made comfortable with dry grass.

Destructive to crops. "Throughout their range pocket-gophers are very destructive to crops. They eat the roots of fruit trees and in this way sometimes ruin whole orchards. They eat both roots and tops of clover, alfalfa, grasses, grains, and vegetables, and are especially harmful to potatoes and other tuberous crops. Besides this, they throw up innumerable mounds of earth in meadows, pastures, and grain fields, which cover and destroy far more of the crop than is eaten by the animals or killed by having the roots cut off. These mounds also prevent close mowing, so that much of the hay crop is lost, and the pebbles they contain often break or injure farm machinery. The loss due to gopher mounds in the clover and alfalfa fields in some of the Western States has been conservatively estimated at one-tenth of the entire crop. In many of the fertile valleys where they abound the animals are by far the most formidable of the farmer's mammalian enemies. In addition to all this, 
in the far West they burrow in the banks of irrigation ditches and thus cause extensive breaks, the repair of which results in the expenditure of much time and money.', (Lantz.) An enemy to orchard and forest. Recently, attention has been especially called to the injury done to orchards and nursery stock, often before the owner becomes aware of the presence of the animal, and it is evident that great watchfulness should be maintained by tree planters in gopher-infested country. This watchfulness should be especially alert where the orchardist, in order to prepare the soil, first raises and turns down crops of alfalfa, clover or cowpeas, sweet potatoes or sugar-beets. Any of these attract the rodents, and make their attacks more than likely upon the newly planted saplings.

A gopher which in tunneling comes to a tree root attacks and eats through it. If the root is relished, it is followed and eaten close up to the tree trunk. Then another root is destroyed, and so on until the entire root system is gnawed away, wood and bark alike, leaving the trunk loose in the ground. 
The rapidity with which the animal works is amazing. In his rare monograph on the family Merriam assures us that a pocket-gopher can make two hundred complete strokes with his teeth in a minute. Its jaws are so arranged that thirty-eight distinct single cuts are made

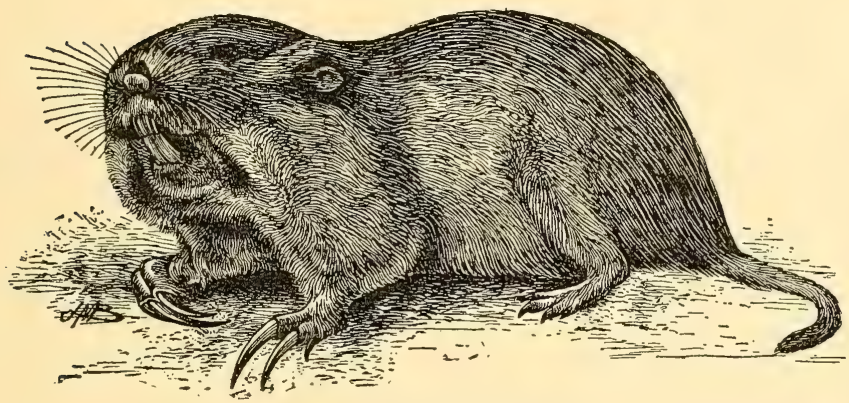

SOUTHERN POCKET GOPHER (GEOMYS BURSARIUS).

From a Painting by E. T. Seton.

by the forward stroke of the jaw and twentyeight by the backward stroke. Thus, the little creature's jaws may make a grand total of 13,200 cut a minute when in active operation!

Large trees are sometimes entirely girdled 
just below the ground, the gopher cutting deep into the wood, causing immediate death. The girdling of large roots is also common. In California the fig seems to suffer most, but orange, lemon, apricot and all other fruit-trees are attacked.

Complaints from western nurserymen of injury to their stock by pocket-gophers are frequent. The trees in nursery-rows are set small and close together. Consequently a gopher by following the rows can in a short time kill many trees. Such injury is usually done in late fall or winter, and the nurseryman is often unaware of it until spring. The gopher takes the entire root, not merely the bark, cuts it into short pieces, packs them into its enormous cheek-pouches, and carries them away to its food-câches, which sometimes contain half a bushel of such provender. Plantations of young trees for wind-breaks or ornament, or to afforest a district, are equally hurt; in fact the gophers are worse than rabbits, because they work unseen and almost invariably kill instead of merely injuring the trees. Wherever they abound orchards are almost an impossibility. 


\section{THE GRAY GOPHERS}

Tapping irrigation-ditches. Another most serious mischief, in regions depending on irrigation, is the destruction of ditch-banks. Sometimes the animals are forced out of irrigated land and take up new quarters in the dry ditchbanks, or in course of the regular extension of their tunnels a ditch is encountered and the bank is followed in search of a crossing-place. In either case the burrow is almost sure sooner or later to penetrate below the water-line and start a leak that cuts out the bank and empties the ditch. Altogether, it has been estimated by the Biological Survey that the loss due to gophers in the western United States is not less than a million dollars a month.

"No animals," the Survey declares, at the same time, "are more easily controlled on a small farm or along ditches than gophers. They are readily trapped or poisoned, and once cleared out of a field others do not come in at once. Their mode of travel, which is principally by extending their burrows, is of necessity slow; and if occasionally caught or poisoned around the edge of fields or along ditches, they can be effectually controlled.' 
This implies that the damage done is largely the result of neglect on the farmer's part.

The gopher as a soil-maker. In view of this record of harmfulness (due, of course, simply to mankind trying to modify nature for his own ends in the path of the animal's natural way of living, so that from nature's point of view the cultivator is the aggressor and the gopher merely defending himself and living off the enemy), it is only fair to point out how the animal, throughout the history of the species, has been laying the present farmer and ranchman under his debt.

"For unknown ages," declares Dr. C. Hart Merriam, in the monograph already referred to, "the gophers have been steadily at work plowing the ground, covering deeper and deeper the vegetable matter, loosening the soil, draining the land, and slowly but surely cultivating and enriching it.",

Ernest Thompson Seton illustrates this statement very forcibly by the example of Manitoba,- - one of the richest soil-areas in the world-where, as elsewhere in northwestern 


\section{THE GRAY GOPHERS}

Canada, there are no earthworms to act as prehistoric cultivators. The black loam there is from one to two feet thick, and is a thoroughly mixed soil of both mineral and vegetable particles. There is no doubt that, in the absence of earth worms, this mixing is done by burrowing animals, by far the most important of which is our subject. In his great work, Life Histories of the Northern Animals, Seton shows by text and drawings what an astonishing number of active gophers there are (or were) over every square mile of that and other regions; and the still more astonishing bulk of soil brought to the surface from deep layers day by day. He cites a district in California with an estimated average of 6,000 hills to the acre, and enough soil heaved out each summer to cover the whole with an inch of new earth; and other similar cases elsewhere. "If the fertility of tens of millions of acres of land in the Northwest, and consequently their value, has been mainly the work of moles [pocket-gophers],', declares Dr. Robert Bell, the Canadian geologist, after giving proof for his thesis, "these 
apparently insignificant little creatures may be regarded as the most important of the native animals of the country.',

If Mr. Gopher could speak he would probably remind the agriculturist of this, and ask whether the delayed fees he was now exacting were too large for the service.

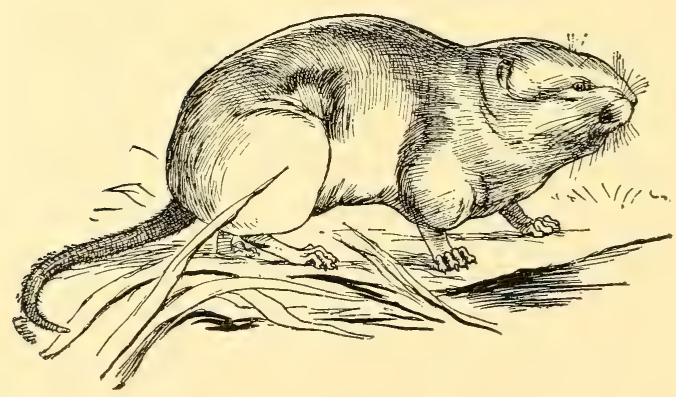




\section{CHAPTER VIII \\ SQUIRRELS, GOOD AND BAD}

A view of our tree-squirrels. The badge of the true squirrel is his plume-like tail, which, though it seems to our eyes only an elegant ornament, is to him a balancing-pole assisting his agile bounds from branch to branch, an umbrella by day, and a blanket when he withdraws to his hole for the night. No better type of this delightful group can be found than the red squirrel,- - the genius of the American woods. He is exceedingly common, not at all shy, and recognized by almost everybody, yet few persons know really much about him. There is practically only one species on the continent, but local varieties differ much in size and colors. Those in the South are larger and redder, for example than those of Canada; and on the Pacific coast, where they are called pine-squirrels, their coats are almost brown. Their colors vary also with the seasons, the 
winter coat being paler and lacking the black side-stripe which so handsomely borders in summer the rufous mantle of the back.

Red squirrels at home. The red squirrel's home is properly in some hollow of a tree or

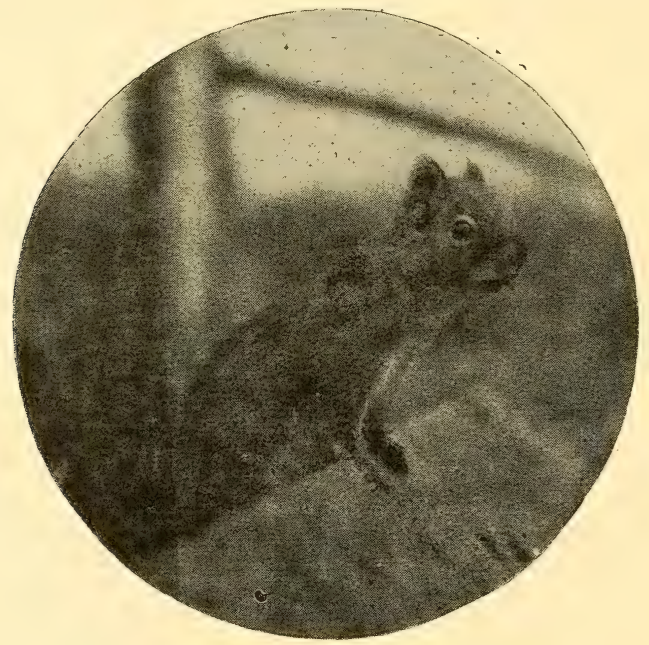

A NORTHWESTERN RED SQUIRREL.

From a Photograph by James A. Donaghy, Elphinstone, Manitoba.

stump, sometimes low down and hence dangerously exposed to foxes, weasels and snakes. Frequently he chooses to live in a hole beneath tree-roots or some old stone wall, adapting to his purpose an abandoned chipmunk burrow 
or the hollow left by a rotting root, and extending it into various connecting chambers. In the evergreen forests of northern New England and Canada, however, he often constructs a winter nest among the dense foliage of a spruce or cedar, which is a marvel of workmanship. "When convenient," to quote Cram's account of those familiar to him, "he chooses the nest of some large bird for a foundation, and in this builds a structure of moss, bark, pine-needles, and dead leaves, with walls several inches in thickness, and a soft nest of dry grass and feathers inside. The bark used is of two sorts, the rough outer bark of different trees broken into small pieces, and what appears to be the inner bark of the red cedar, torn into narrow strips or ribbons to bind the whole together. It is put together with remarkable solidity, and usually freezes hard early in the winter, furnishing a thorough defense against the cold or any other enemy from without. The narrow opening at one side is provided with a hanging curtain.",

These tree-houses are, however, abandoned in the spring, when they become soaked with 
rain, and a hollow tree is sought and furnished with clean bedding of moss, lichens, etc. Here the young are born rather early in the season, -five or six of them,-and there they remain together until fully grown.

"The young squirrels," to quote again Mr. Cram's delightful history, "are most absurd looking little beasts at first, like miniature pug-dogs, blind and naked, with enormous heads. In a few days their fur begins to show like the down on a peach, and as a fringe of short hair along each side of the tail, which at length assumes something of the flattened aspect of that worn by their elders, but without displaying much of the fluffy, shadowy quality of the ideal squirrel tail until late in the following autumn.

Although they do not remain long in the nest, they are seldom seen abroad until fully grown, or very nearly so, at least, which is rather remarkable when you come to consider the number that are brought up each summer in every pine grove or thicket where these squirrels are abundant.

How a red squirrel fares. The red squirrel eats almost anything he can lay his teeth to, but his chief diet, of course, consists of berries, nuts, acorns and similar hard fruits, especially the seeds found in the cones of evergreen trees - the mainstay of those living in 
the far northern woods. In the early spring he must often content himself with buds, preferring those of the maple and elm; and it is a pretty sight to see him and his friends dangling from the tips of the swaying branches, perilously high, reaching for the bursting buds. In March he taps the maples for sap, cutting out little cups in the bark, in which the sugary liquid gathers and is lapped up, for he drinks like a cat. He climbs rotten stubs and, like the woodpecker, listens for noise made by insect larvæ, which are quickly dug out. $\mathrm{He}$ searches for haws of the rose and thorn-trees, and hunts through the orchard for old apples now thawed soft.

A little later, I am sorry to say, he is on the lookout for birds' eggs and young, of which he destroys far more than any other squirrel. No nest is safe from his inquisitive eye and eager appetite, even the Baltimore oriole's, but he is often driven away by the owners. Nestlings are more to his taste than eggs, even; and now and then he is able to catch small birds, or even mice and little snakes, while grasshoppers and fat larvæ are a regular part of 
his bill of fare. Few animals, remarks Manly Hardy, are more fond of meat:

"They will eat any kind of meat or fish as quickly as a cat and will live on it days when a chance offers. I have often had them eat each other when one was in a trap. Around camps where provisions are stored they are great pests. Their sense of smell must be very acute, as I have seen where one gnawed a large hole through a new overeoat to get at a bottle of coffee which one of my men had rolled up inside to keep it warm. The squirrel must have smelled it through all the folds of the thick cloth. Where not troubled they soon become very tame, often coming into a camp and stealing biscuit or gingerbread from the table. I have seen those which certainly could tell one person from another, as they would let one who had never molested them come very near, while, when a person who had stoned them appeared, they would instantly dodge into a hole."

As summer advances the red squirrel finds ripe berries and fruit to his taste, and in July begins, in the northern coniferous woods, to attack the green cones, especially of the white pine, cutting them off "and burying them, half a dozen in a place, under the pine needles, to be dug up in the winter and spring, and opened for the seeds they contain." At this season, 


\section{SQUIRRELS, GOOD AND BAD 131}

too, he bites into many mushrooms, especially those which grow upon old wood; and certain of these he stows away in dry places for future reference.

Preparing for the winter. This squirrel is a hard worker at all times,-the merriest sprite of the woods, yet always industrious and thrifty; but his busiest time is in autumn when the ripening nuts must be harvested. In the forests of the southerly portions of his range, butternuts, hickorynuts, and those of the chestnut, pecan, hazel and beech, with acorns and chinkapins, are most important. Their substance is not very nourishing, but they supply in abundance the fat which is so necessary for animals to accumulate in the autumn as a fuel to keep the fires of life burning during the winter. In the Southern States the winters are so mild that there is not the need to lay up the large food-supply required in the North, and methods vary, too.

Instead of having a single storehouse, as do most other provident rodents, the red squirrels bury a part of their gains, one or a few nuts in a place, and hide the rest in a variety of nooks 
and crannies. It is thus difficult to judge what this scattered accumulation amounts to in the aggregate, but it is probably a good deal more than one animal wants. The little rascals seem to recognize no property rights in these savings, but during the winter seize anything they can find, so that fierce fights are always happening, in which the thievish grays take a full share. With a short account by Mr. Hardy of the cone-saving squirrels of the northern woods I will conclude this part of the subject: ${ }^{1}$

Storing pine-cones. "With us [in Maine] he lays up large stores of the cones of pine and spruce and knows the exact season when they are fit to cut for his use. If cut too early they will be sealed closely with pitch; if cut too late the winged seeds will have escaped. The red squirrel cuts them by the hundreds the last of September, just when the sticky covering has hardened into drops of stiff pitch and just before the cones have opened. One who is in the pine woods then will hear the dull, heavy thud as they fall, and if he gets a close view of the squirrel, will see that his paws and face are smeared with pitch.

1 A full discussion of the meaning of this custom of storing food against a coming time of scarcity; and of its probable origin and development through the influence of natural selection, will be found in the chapter entitled "A Squirrel's Thrift," in my Wit of the Wild, $2 \mathrm{~d}$ edition, Dodd, Mead \& Co., New York, 1911. 


\section{SQUIRRELS, GOOD AND BAD 133}

"The squirrel knows exactly how to get the seed with the least labor. A squirrel wishing to eat a cone, sits up on his hind feet, standing the cone up before him on its small end. Then he cuts off the upper scale at the butt of the cone. These scales do not run in straight lines, but are arranged spirally, with a seed under each scale. The seeds in a white pine-cone are about the size and shape of a small apple-seed; those of a spruce, about as large as seeds of turnip or mustard. Both kinds have a wing which serves to carry the seed often to long distances, when it falls naturally from the cone. The squirrel eats the first seed, then gives the cone a slight turn and cuts the next scale, and so keeps turning and eating until the central pith is in his way, when he cuts it off and continues eating until near the end of the cone, which he always leaves, as he knows that the seeds there are too small and poor to be of use to him."

Gray squirrels and fox-squirrels. The red squirrel has been given so much space because his life is typical of that of the tribe, and because he is not accurately known although so widespread and numerous.

More familiar to most readers are the large "gray" and "fox" squirrels, both of which are very variable. Thus the northern gray squirrels are at their best a clear silvery tint, while 
southward they become yellowish or rusty, and in some localities a black variety is prevalent. Well-grown specimens of this species are about 18 inches long, including the splendid feather of the tail. West of the Alleghenies, to the border of the Plains, and as far north as South Dakota, lives the northern fox- or cat-squirrel, which is larger (23.5 to 25.5 in.), and in general tint foxy red; but the species is extremely variable, one large southern variety being wholly black save the white nose and ears, and a good deal of black and orange are likely to appear on any specimen, north or south. It may be mentioned here that Mexico has among its many species and races of squirrels perhaps the most beautiful of any in America, -the red-bellied. "Its upper surface is pale grizzled gray, and its under parts bright rusty red; it inhabits the forests of eastern Mexico, ascending the high mountains to an elevation of 8,000 feet."

It is only in the Appalachian region that the gray and the fox-squirrels meet. They are much alike in habits, and both have become bold acquaintances of civilized man, and are 


\section{SQUIRRELS, GOOD AND BAD 135}

public pets in a thousand villages and urban parks. In some places, indeed, they are so numerous and bold as to injure gardens, and to work ruin in roofs and cornices by digging through them to make their nests inside. As pets in captivity they, like the reds, are not very desirable, since they grow cross with age, and if more than one is kept in a cage the strongest will probably kill or injure the others. If allowed the freedom of a room they will work havoc, and prove practically untamable.

It is as easy and much better, however, to domiciliate them in the trees about the house, by placing high among the branches cabins (short sections of hollow logs are best), and protecting and feeding their tenants. They will come to a window-sill where you place regularly cracked nuts, grains of corn or bits of cracker, and you will enjoy their society much more in their free shy activity than if they were immured in a small wire jail. A good plan, if you like their visits to your windowsill, is to provide them with a pole-bridge from the nearest tree, as they are shy of going upon the ground where dogs and cats may be. 
Peculiarities of these larger squirrels. In one or two respects the gray and the fox-squirrels differ decidedly from their smaller relatives. Instead of retiring to holes underground, they dwell in winter in holes in trees, coming out nearly every day to hunt and gambol about. They make great summer nests of leafy twigs in which the mother and young reside while the male squirrels lead a bachelor existence, often with far wanderings. Their food is substantially the same as that of the reds, but they rarely rob the nests of birds, or are thievish of meat; and their only method of storing food is by burying it, one nut or acorn in a place. That months later, when wind-blown leaves and perhaps deep snow cover the ground, they can recover these treasures is truly remarkable; but they seem to know precisely where each nut is buried, and go directly to it, then dive down through the snow and presently reappear with the morsel in their teeth. It would seem improbable that this is an effort of memory, and more likely that a certain amount of memory is aided by the faculty of smell. Often after finding one buried nut 


\section{SQUIRRELS, GOOD AND BAD 137}

they bore their way beneath the snow here and there in search of others, and so get a whole meal.

These squirrels are so large and toothsome that they have always been reckoned among our game animals, and years ago were to be seen in every market in the land. Now this is less common, because they have become scarce in many parts of the country. No longer, then, are they accused by farmers of being a pest; but a century ago they certainly were so all along the frontier. That was the time when occasionally vast migrations descended upon the fields of corn in the milk, ruining the crop; and for years great sums in bounties were paid for their destruction in Pennsylvania and Ohio. A very full account of this matter, and of the gray squirrel generally, may be found in the first chapter of my Wild Neighbors.

The gray squirrel of California is a separate species, larger and brighter than the eastern gray. Along the Mexican border occur several allied species, more or less marked with yellow and reddish, of which the handsomest is Abert's, which has a band of chestnut along the 
spine, side-stripes of black, white underparts and feet, and tufted ears. It is also found in the mountains of Colorado.

The squirrel that flies. All squirrels are clever at falling. They often slip at great heights, and when they can not clutch a lower branch will turn in the air, spread out their legs and usually alight without harm. The skin is loose, and is pulled far out when the legs are widely stretched; and in one sort the side fold is so ample as to form a regular parachute, enabling the animal to make long slides through the air; it becomes, in fact, a living aeroplane. This is the flying-squirrel, the prettiest fourfoot in the American woods.

There are two species. One dwells in northern Canada, measuring 14 inches in length, and is cinnamon-brown above (sooty in winter), with a black ring around the eye, and the fur of the whitish underparts gray near the roots. A smaller variety occurs in the St. Lawrence Valley. The other species is the common one of the eastern and southern half of the Union, which is only about 9.5 inches in length. Its fur is dense and exquisitely soft, with the tail 


\section{SQUIRRELS, GOOD AND BAD 139}

almost as flat as a feather; the color is drab above, irregularly tinged with russet, while the hair of the underparts is pure white to the roots. Cram notes the "protective" similarity of their clouded cream-buff colors, to the lichens on the trees to whose bark they often cling motionless for long periods. They are not much exposed to any but nocturnal enemies, such as owls and the weasel tribe, however, so that this similitude cannot have much practical importance. They are forest folk, haunting the hardwood groves, and few farmers suspect how many of these tenants profit by the old stubs left along the edges of their clearings. Really they are tenants of the woodpeckers, who are good enough not to occupy one of their carefully dug nesting-holes twice, but to leave it to the occupancy, rent-free, of squirrels, chickadees, little owls and other feebler neighbors. The squirrels are capable, however, of carving out a deep hole for themselves, or will take possession of some natural cavity, and in it arrange a luxurious bed of shredded bark, etc., mingled with the fur they shed plentifully in the fall. Sometimes many will room together 
in a large cavity. Now and then a pair will form an outdoor ball-like home in some old bird's-nest; or will even invade the garret of the farmhouse.

Charm of the flying-squirrel. Strike one of these tall stubs a smart blow with an ax or stone and the squirrels will come pouring out of their hole and go sailing away to neighboring trees like birds. They alight near the bases of the trunks and scamper upward to prepare for another glide, but unless sharply pursued will quickly turn to have a curious look at their disturber. Their "flights" are made upon the parachute of loose skin which extends in a furry fold down to the feet, and is further supported by a slender curved bone hinged to the back of the wrist, while the flat tail acts as both balancer and rudder as in a bird. When starting from a high perch, and going down hill, they may sail 200 or 300 yards; but have little or no power of deviating from the straight line of the intended leap, yet make a quick upward curve as they alight. Audubon and Bachman have given a delightful account of their gambols on 


\section{SQUIRRELS, GOOD AND BAD 141}

summer evenings near Philadelphia, about 1840 :

"During the half-hour before sunset nature seemed to be in a state of silence and repose. The birds had retired to the shelter of the forest. The night-hawk had already commenced its low evening flight, and here and there the common red bat was on the wing; still for some time not a flying-squirrel made its appearance. Suddenly, however, one emerged from its hole and ran up to the top of a tree; another soon followed, and ere long dozens came forth and commenced their graceful flights from some upper branch to a lower bough. . . . Crowds of these little creatures joined in these sportive gambols; there could not have been less than 200. Scores of them would leave each tree at the same moment, and cross each other, gliding like spirits through the air, seeming to have no other object in view than to indulge a playful propensity."

Family life of the flying-squirrel. Not very much is known of the winter life of the ordinary or southern flying-squirrels, but they seem to retire to their warm nests as soon as cold weather comes, and to stay there until spring. This would mean hibernation, or else the storing of food in their holes; and that the latter is their habit would seem indicated 
by the actions of captives to be mentioned presently; but if so it presents a curious anomaly to the rule, for it is certain that the large northern species, although dwelling in much colder regions, where proper food is apparently scarcer, does neither, but goes abroad every evening, no matter how severe may be the cold, to get its subsistence, and fares well.

The young are born in early spring, and when about six weeks old begin to appear at the door of their house, playing about like kittens under the watchful care of their mother.

"And what a lovely little mother she is! She takes the greatest care of them from the time they are born. She tucks them under her, pulls the cedar bark over them and blocks up the entrance on cold days to keep them warm. If you put your finger into the hole she will rake all the babies out of harm's way with her front paws, and then with her nose she will make a determined effort to push your finger out of the hole again. Failing in that, she will not bite you, as a red squirrel would have done at the beginning, but she will probably take your finger gently in her teeth, as though to ask you please to be a gentleman and refrain from causing her any further annoyance.

"Even if you remove the young ones from the nest she will not bite you, but she will come out after 


\section{SQUIRRELS, GOOD AND BAD 143}

them at once in evident distress. If they are near the mouth of the hole, so that she can reach them without leaving the nest entirely, she puts out her head, seizes the youngsters by the neck or back with her teeth and pulls them in after her, one by one. But if she has to leave the nest altogether she picks the children up, turns around and pushes them into the hole before her. A flying-squirrel once disturbed in this way is not likely to allow the matter to pass unheeded. She is almost sure to remove her family to a new home at the first opportunity.'

Taken young, and fed on milk and vegetables until they get their growth, they form delightful pets, though mischievous ones, unless their activity is curbed. It is from captive specimens, indeed, that we have learned most that we know as to the habits, tastes and dispositions of these secretive little creatures. 


\section{CHAPTER IX \\ GROUND-SQUIRRELS AND PRAIRIE- DOGS}

We come now to the ground-squirrels, which are of small size, have flat and comparatively short tails, and keep near the earth, living beneath it and deriving their food from weeds and low bushes for the most part. There are scores of species which fall into two groups,the striped chipmunks of the eastern and northern woods, and the unstriped spermophiles of the western plains.

The chipmunks. Our familiar chipmunk is the only eastern representative of this large group, and is seen everywhere. In size and manners he is much like the saucy red squirrel, but the five black stripes alternating with two whitish ones on his chestnut coat (fading through yellowish on the sides into a white vest), distinguish him in an instant. His race extends clear across the continent and to Alaska. wherever timber grows, but the western 
varieties differ so much in size and tint that the early naturalists made several species.

"This squirrel," to quote the pleasant phrases of Dr. Godman, "is most generally seen scudding' along' the lower rails of the common zigzag' or 'Virginia' fences, which afford him at once a pleasant and secure path, as, in a few turns, he finds a safe hiding place behind the projecting angles, or enters his burrow undiscovered. When . . his retreat is cut off he . . . runs up the nearest tree, uttering a very shrill cry or whistle, indicative of his distress, and it is in this situation that he is most frequently made captive by his persecuting enemies, the mischievous schoolboys.',

No animal is better prepared than the chipmunk to withstand the cold and hunger of a northern winter, for he has learned how to construct a model home and to provision it well.

The burrow and its furniture. This is a burrow which usually begins beside a stone or among the roots of a tree where it will not attract notice, moreover all the earth that is taken from the hole is scattered at a distance in order not to betray the excavation. It is first carried 
straight down in a narrow shaft below the frost line, then turns and winds away horizontally, and as the tunnels are used year after year, with continual enlargements, old ones may reach to a great length, with branches and chambers accommodating several pairs, and secret exits. In the autumn one of the underground chambers is furnished with soft bedding and becomes the living-room of a family, while other chambers are stored with provender or set apart as receptacles for refuse. Now the chipmunk becomes exceedingly busy, fattening himself upon the ripening nuts and seeds, not only, but upon many tuberous roots, mushrooms and green corn. On each side of his mouth, separated from it by thin partitions of muscular skin, are large cavities or pouches, opening behind the teeth, which are as useful to him as are our baskets and wheelbarrows to us. He brings to the surface in them the material excavated from the distant ends of his burrow, and after packing them full of seeds or nuts he returns to empty their loads-perhaps half a pint at a time-in one of his storehouses. All the ground-squirrels have such cheek-pouches; 
and so they can speedily gather, while they are plenty, the large stores they need to preserve life during the long season of famine ahead; and snug in their warm nests deep under the sod, they doze away the winter, now and then emerging when the February sun tempts them out, but for the most part lying close, yet not in complete dormancy.

Taking the freedom of the camp. These cheerful little fellows, and especially the fourstriped Rocky Mountain kind, are extremely numerous in the rougher parts of the West, and are amusing visitors at every camp and cabin until they wear out their welcome by misbehavior. In some of the national forests they have proved a great nuisance by digging up newly planted tree-seeds.

"In camp," writes an explorer of MIt. Shasta, "they made frequent visits to the mess-box, which they clearly regarded as public property, approaching it boldly and without suspicion, and showing no concern at our presence-in marked contrast to the goldenmantled squirrels, which approached silently, stealthily, and by a circuitous route, in constant fear of detection. If disturbed while stuffing their cheekpouches with bits of bread, pancake, or other eatables, 
each chipmunk usually seized a large piece in its mouth and scampered off, returning as soon as we withdrew. In fact they made themselves perfectly at home in camp."

The striped gopher and spermophile. A variety of this species, the sage-chipmunk of

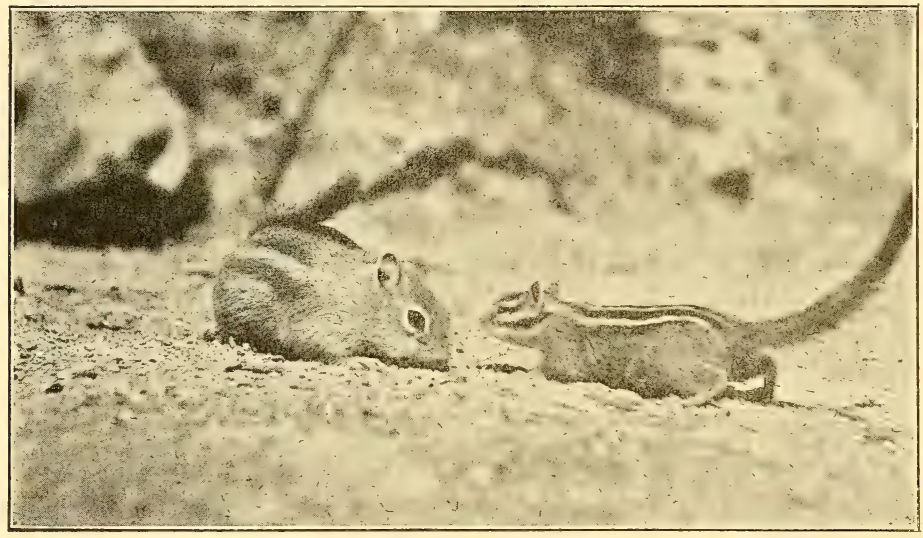

TWO SPECIES OF ROCKY-MOUNTAIN CHIPMUNKS.

From Warren's "Mammals of Colorado." By Permission of G. P. Putnam's Sons. Photo by H. W. Nash.

the Great Basin, is the smallest and sprightliest of the race. It lives mainly in the sage-brush, scrambling about these diminutive bushes or scampering from one to the other, and often sitting on the top of a sage-bush eating the little seeds from its hands; but, like other 
squirrels they vary their seed-diet with insects. It is a relative of these chipmunks, marked by thirteen stripes, dark brown on rusty yellow, which is known throughout the Northwest, from Lake Michigan to Alberta, as the "striped gopher," and as a pest to farmers on account of the grain it steals and the runways for water its burrows make. Still worse are several other northwestern ground-squirrels which have plain yellowish-gray coats and are known as "gray gophers;" though the term "gopher", should be restricted to the Geomys; the most familiar is Franklin's spermophile.

This graceful animal was originally abundant as far south as central Missouri and Illinois, but long ago disappeared before the civilizing of its prairie home, and now remains numerous only in the wilder districts of the Dakotas and northward. It is pretty and interesting, but too much of an impediment to good agriculture to permit the farmer to tolerate it; yet the animal increases so rapidly under the protective and food-supplying conditions which the human settlement of the country brings it, that its extermination will be a matter of great diffi- 
culty. Referring to this matter Dr. Merriam made the following appealing remarks in a recent paper on these pests in California:

Striped spermophiles exist along the grassy eastern border of the plains right down to the Gulf of Mexico; and Texas has, besides, a beautiful little "sand-squirrel," spotted with white on a yellowish ground, relieved by black markings. It is a shy, inconspicuous little creature, rarely noticed until it attracts attention by a fine trilling bird-like whistle. These and other spermophiles are most numerous where the mesquit grows, for its seeds afford them good food. They are fond, too, of the fruit of the small prickly pear, the sand-bur, and other shrubs and weeds, and eat many grasshoppers and other insects. The graceful antelope-squirrel, taking its name from its colors, is another species conspicuous for its beauty, carrying its short, wide, white-lined tail curled over its back like a plume. All these burrow at the edge of thickets and cactus clumps and apparently hibernate. Sometimes they do much damage by boring through the banks of irrigating ditches. Another south- 


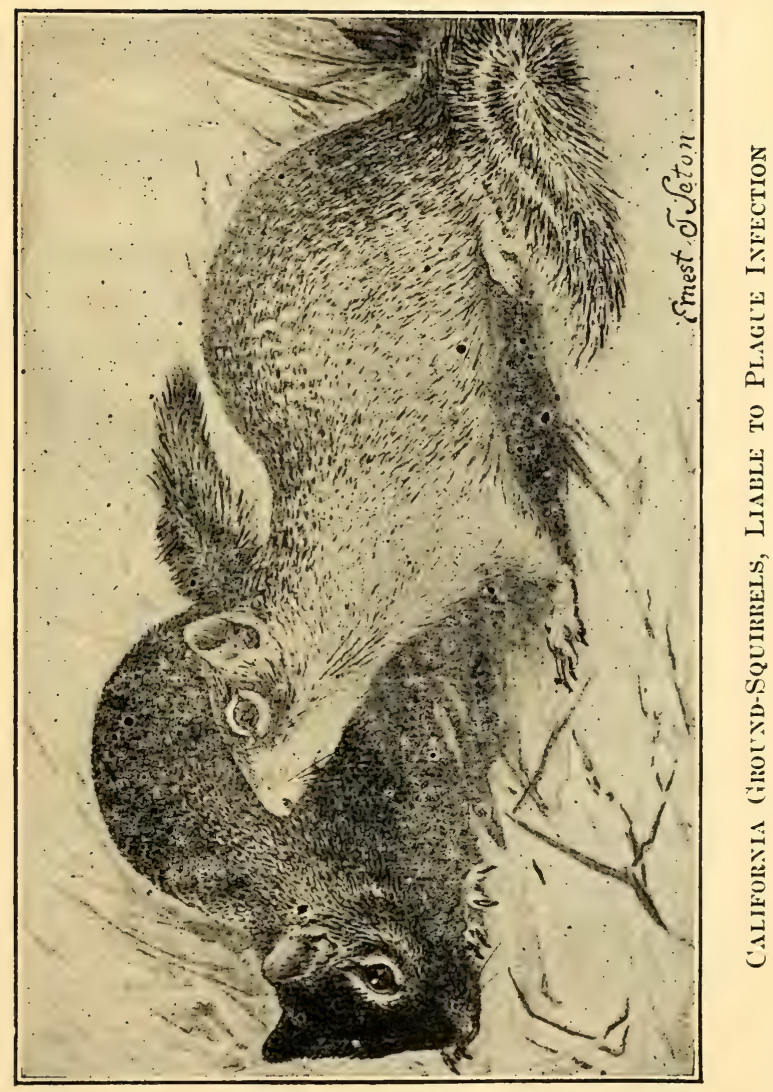



western group includes the rock-squirrels, which are never seen far from cliffs or broken ledges. Bailey tells us that they climb the trees for acorns and berries, but when surprised always rush to the ground and scamper away to the nearest rock-pile. They are extremely wary. "Like most of the smaller groundsquirrels of the arid regions they usually burrow under a cactus or some low thorny bush, where they obtain shade and the protection of thorny cover. They apparently do not hibernate, but during the cold weather have the unsquirrel-like habit of closing their burrows and remaining inside, as a protection against enemies, and especially snakes. . . Like other members of the genus, these groundsquirrels feed on seeds, grain, fruit, green foliage, lizards, and numerous insects, and often gather around gardens and green fields, where they do considerable damage in spring by digging up corn, melons, beans and various sprouting seeds, and, in summer and fall, by feeding on the ripening grain."

Squirrels and bubonic plague. One of these ground-squirrels, that most common in central 
and southern California (Clitellus beecheyi) has special prominence in our list because it shares with the rat the bad distinction of being a dangerous carrier of plague-germs. It was observed as early as 1903, as we learn from Professor Doane's book previously alluded to, that an epidemic was killing these ground-squirrels in the neighborhood of San Francisco bay. The matter was at once investigated by Dr. Rupert Blue, of the U. S. Public Health and Marine Hospital Service, who speedily ascertained that the disease was bubonic plague, which had probably been caught from the town rats which at harvest time wander into the country in large numbers and make free use of the holes and runways of the field-squirrels. A single infected rat might sow the seeds, for its fleas, escaping, from its dead body, would readily attach themselves to a squirrel and multiply and spread among them. Among the tens of thousands killed and examined a considerable number of infected ones have been found; and several instances are recorded in which human cases of plague in California resulted from handling infected squirrels. 
Whether the disease has been exterminated among these wild rodents, remains to be seen. The fact that the Beechey ground-squirrels have shown themselves receptive to the fleas which are peculiar to brown rats, and to the disease, led to observations and experiments as to other rodents. It is found that rock-squirrels are quite readily infected, mice and pouched gophers less so, but wood-rats and prairie-dogs succumbed at once. There seems no reason to suppose that any rodent may not carry the fleas about in its fur a short time, if not permanently; or that any rodent is immune against the plague if punctured by an infected flea. A ray of light is shed upon this dark aspect of the case by the announcement that along with the fleas goes a small staphylinid beetle which exists as a parasite on both rats and squirrels, and feeds ravenously on the fleas.

Importance of the prairie-dog. But of all the ground-squirrels none equals the prairiedog in interest or importance.

It is a denizen of the dry plains east of the Rockies, while two or three other species inhabit the mountains, the Utah basin, and 
southward into Mexico. This animal is sometimes confused towards the north with the

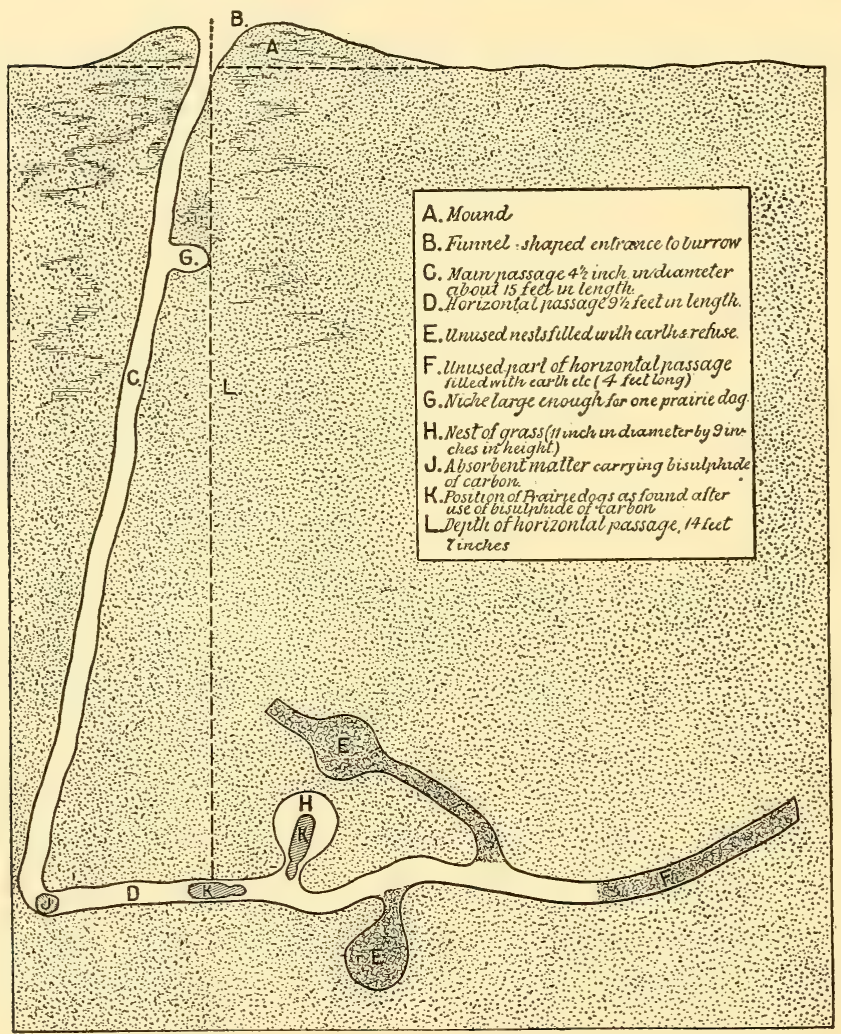

DIAGRAM OF A PRAIRIE-DOG'S BURROW.

larger gray gophers, especially the Columbian and Franklin's, so that we wrongly hear of 


\section{PRAIRIE-DOGS}

"prairie-dogs" on the Canadian plains; it is to be distinguished by its slightly larger size, distinctly brownish color, and very short tail (two inches), which is flat and black toward the end.

The prairie-dog is about a foot long, and robust, with strong limbs and claws. It dwells in colonies, whose permanent "towns" of burrows, each marked by a hillock of earth about the entrance, spread densely over many acres under the natural prehistoric conditions, but now sometimes cover hundreds of square miles. The burrows are deep and extensive, and at first go down at a very steep slope to a depth of twelve to fifteen feet, when they turn horizontally, and here and there branch into chambers, some of which are family rooms, while in others fodder is stored, or refuse and dung are deposited. The mound about the hole is packed hard, not only by the tramping of the animals, but by crowding it down with their noses; this hillock prevents water from running into the burrows when the plain is flooded by heavy rains, and also serves as a tower of observation. 
"The prairie dogs feed upon grass and herbage, which is soon exhausted near the burrows, compelling the animals to go farther and farther away for food. This they dislike to do, as it exposes them to attack from enemies; and after a time they prefer to dig a new burrow nearer a supply of food. Thus a 'town' is always spreading and contains many empty burrows. Like other animals habituated to desert regions, they do not drink at all. . . . The animals are diurnal and most active morning and evening. They come out daily during the winter, except when it is very stormy; but this practice varies with the latitude and climate.

"They are prolific, especially in the southern half of their territory, and would multiply with excessive rapidity were it not for numerous enemies, especially rattlesnakes and other serpents. These are courageously resisted by the prairie dogs, who sound the alarm the moment a snake enters a hole, gather, and proceed to fill the entrance with earth, packing it down, thereby sometimes entombing the snake forever. Probably few snakes go down the passages, which are so steep they could with difficulty climb out, but depend upon lying hidden in the grass and striking down the young squirrels when out at play or in search of food. This is the method of the coyote, kit-fox, wildeat, hawks, and owls, who find the dog-towns a profitable hunting-ground. Badgers, however, can, if they will, easily dig up a burrow and devour the helpless family. The worst enemy is the black-footed ferret, a weasel of the plains, which 
easily penetrates the burrows, and against whose ferocity and skill the squirrels can make little defense.

"All these conditions together served in the natural state of things to hold the prairie-dogs in check, but the changes brought about by civilization have been so favorable to these little animals, by the reduction of their enemies on the one hand, and the augmentation on the other hand of their food supplies by the farmers' plantations of meadow grass, alfalfa, and grain, that they have increased into a very serious pest."

A serious pest-problem. How serious this pest has become in the grazing regions of western Kansas, Oklahoma and Texas, may be inferred from the information furnished by Ternon Bailey in his report upon the conditions in Texas in 1905.

"Usually," he states, "they are found in scattered colonies, or 'dog-towns,' varying in extent from a few acres to a few square miles, but over an extensive area lying just east of the Staked Plains they cover the country in an almost continuous and thickly inhabited dog-town, extending from San Angelo north to Clarendon in a strip approximately 100 miles wide by 250 miles long. Adding to this area of about 25,000 square miles the other areas covered by them, they cover approximately 90,000 square miles of the State, wholly within the grazing district. It has been roughly estimated that the 25,000-square-miles colony contains $400,000,000$ prairie-dogs. If the remaining 


\section{ANIMAL COMPETITORS}
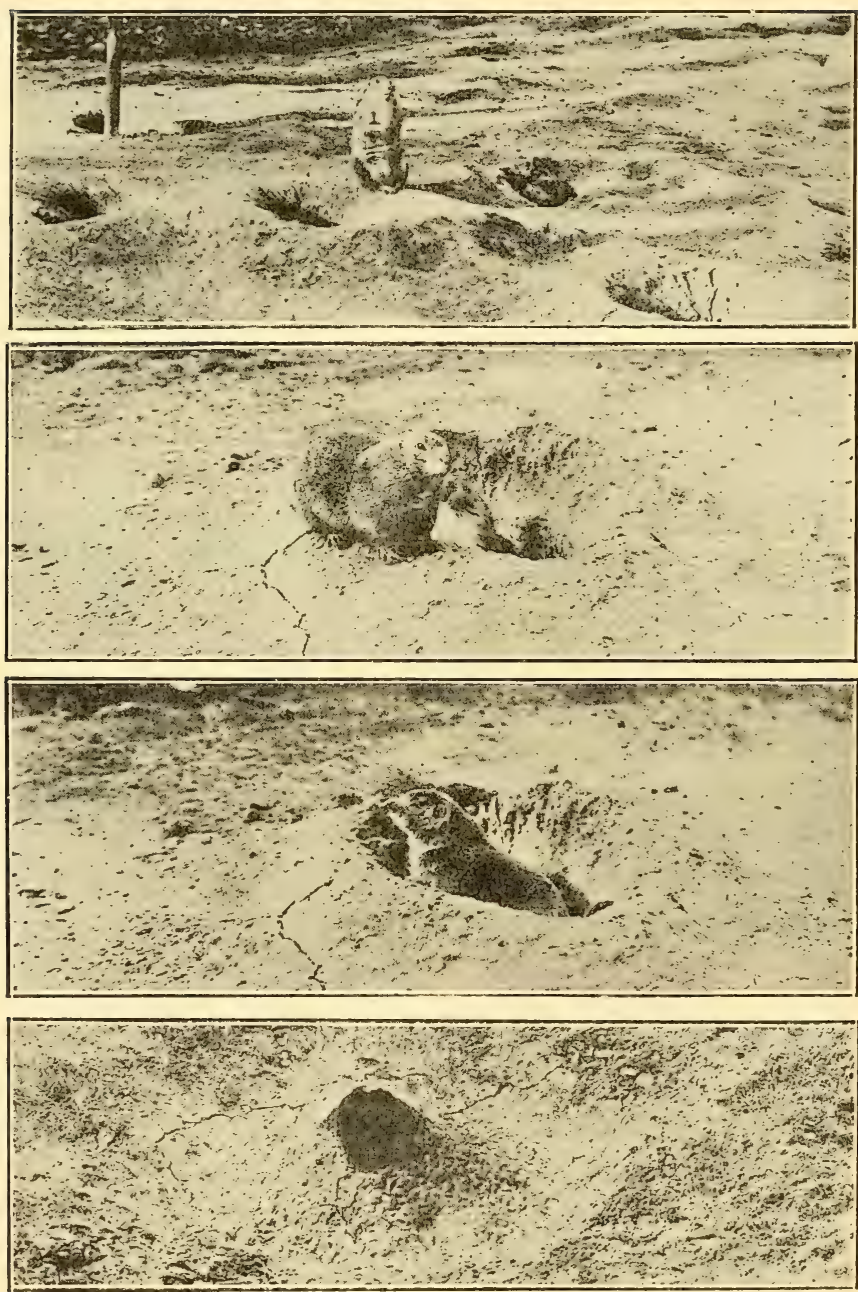

SCENES IN PRATRIE-DOG LIFE。 
65,000 square miles of their scattered range in the State contains, as seems probable, an equal number, the State of Texas supports $800,000,000$ prairie-dogs. According to the formula for determining the relative amount of food consumed by animals of different sizes, this number of prairie-dogs would require as much grass as $3,125,000$ eattle.

"In many places the prairie-dogs are increasing and spreading over new territory, but on most of the ranches they are kept down by the use of poison, or bisulphid of carbon, or, better, by a combination of the two. As a Texas eattle ranch usually covers from 10,000 to 100,000 acres, the expense of destroying the prairie-dogs in the most economical manner often means an outlay of several thousand dollars to begin with and a considerable sum each year to keep them down. The increase of prairie-dogs is clearly due to the destruction of their natural enemies.

"In autumn the prairie-dogs become fat, but in Texas they do not hibernate as they do to some extent in the North. If their fur should become fashionable, or roast prairie-dog an epicurean dish, the problem of keeping them in check would be settled, and there is no reason, save their name, for not counting them, properly prepared and cooked, a delicacy. While owing their name to a chirping or 'barking' note of warning, they are in reality a big, plump, burrowing squirrel of irreproachable habits as regards food and cleanliness. An old stage driver expressed the idea in graphic words one day: 'If them things was called by their right name, there would not be one 
left in this country. They are just as good as squirrel, and I don't believe they are any relation to dogs.' ",

Since the citation above was written the public suppressive measures taken in Kansas have reduced the pest to negligible proportions except in the remote northwestern counties.

The woodchucks. These large ground-squirrels bridge the gap between the true squirrels and the marmots, as they are called in the Old World, known to us "woodchucks", or " groundhogs." They are stout, short-legged, inactive animals, with short tails and closely appressed ears, whose dense fur is grizzled gray, inclined to chestnut or blackish, and whose habits are distinctly terrestrial. Our eastern woodchuck is found everywhere east of the Plains in all open woodlands, prairies or cultivated regions, for he thrives in the midst of civilization, whose cleared fields are to his liking, while he is furnished an abundance of food by the raising of field and garden crops. Few animals are so familiar to the country boy, who early becomes acquainted with its burrows in the hillsides, but rarely has the 
courage to dig the owner out of their tortuous depth. In the West are other similar species; and all the high mountains from the Rockies westward, and far to the North, have a larger one which dwells near timber-line, and is known as the siffleur (whistler) on account of its clear sharp call. The food of all these marmots consists of herbage and succulent roots, and they do great damage in gardens where not restrained. They do not store any of this food, however, but in the early autumn retire to their burrows, very fat, and pass the winter in a state of complete torpor, during the continuance of which their fatness decreases, being absorbed to sustain the trifling exertion of life caused by the continued slow beating of the heart. When, therefore, they emerge early in the spring, they are lean and very weak, but soon recuperate on the fresh grass and herbage. Their fur is of little value, and their flesh poor, so that as game they are attractive only to the boy and his dog, or, in the West, to hungry Indians.

Food-value of the porcupine. Here, if anywhere, should be said a few words about the 
sluggish, stupid northern porcupine, whose relation to man is far more to the good than to the bad. It is true that he strips a few forest trees of their foliage, and occasionally inadvertently girdles one; but his flesh is excellent eating and large in quantity. His nature and habits make it possible to approach him without difficulty and to kill him with a club. Hence he has always been a reliance of the forest-dwelling Indians and white fur-hunters for winter food, and now it is of so much importance in the great forested regions of the Northern States, and in Canada, that timbercruisers and others whose business takes them into the wilderness should be able to find a porcupine in such emergencies as are always likely to arise in their adventurous lives, especially in winter, that the animal is protected by law; and this law is well lived up to by the frontier folks for they appreciate its importance.

At the same time it must be confessed that porcupines make themselves very troublesome in camps or about houses in the woods which are left alone for a time, as often happens 


\section{PRAIRIE-DOGS}

among loggers and miners amid the western mountains. The porcupines at once make themselves at home, and if they can get inside will demolish nearly every wooden thing in their search for food, and their enjoyment of nibbling anything salty. As salt pork and bacon enter largely into the provisions of these people, their tables, cupboards and utensils are likely to be more or less spotted if not saturated with salty grease; and the porcupine knows no reason why he should not get to the last taste. 


\section{CHAPTER $\mathrm{X}$}

\section{RABBITS, USEFUL AND INJURIOUS}

RABBits hold a prominent place among the obstacles to success met with by both the farmer and the orchardist. They number many species, and one or more is present in any habitable part of the continent to which you may refer. The East has in its middle and southern part the familiar and widely distributed gray rabbit or Molly Cottontail, which extends westward to the plains; and the smaller, and redder swamp-rabbit of the South; while in our northeastern States and in eastern Canada the larger American or varying-hare, which turns white in winter, is present, and constitutes the principal winter fare of such worthy animals as the lynx, wolf, for and various martens, and of some harks and owls. In the West the great jack-rabbits ahound, and in the far North the arctic white hares.

Excellence of rabbit-flesh. To the native 164 
people of our forests and plains rabbits were of the utmost importance as food, especially in winter. The early pioneers everywhere relied largely on them. Their thick fur too, was, and is, a precious resource to the Indians, especially those of the Northwest, who make from it artistic as well as substantial garments and coverings.

The smaller American rabbits have long been esteemed as game. While their flesh is less tender than that of the domesticated species it is of much finer flavor, and when properly prepared for the table is much more desirable as food. With the same care in dressing and handling bestowed upon the rabbit in English markets, our cottontail rabbit would stand much higher in popular flavor. The jack-rabbits are not so good, yet many reach the market.

A strong prejudice against eating jack-rabbits often exists because occasional individuals are infested by warbles and the tapeworm larva. Unless badly affected, however, the flesh is not injured by these parasites, and there is no good reason why the animals should not be 
extensively used as food. The half-grown or nearly full-grown young of the year are usually healthy and very good eating when properly cooked. Those not needed for the table may be fed to dogs and poultry, but should be cooked. The principal natural enemies of jack-rabbits are coyotes, foxes, bobcats, hawks, owls, and eagles. When rabbits become abundant these enemies gather to feast on them, and then at least should be afforded protection.

Rabbit fur is not in demand in this country except for trimmings, since it is brittle, has no underfur, and does not wear well; but from one and a half to two million skins are bought annually to be made into felt for hats and similar purposes, and it might be well for farm-boys to enquire whether they could not profitably trap or shoot in their neighborhood for this and the flesh market.

General breeding-habits. Our American rabbits are not so prolific as the common European species. Some of them produce three or four litters of young in a season, while others seem to breed but twice. The period of gestation is about thirty days, and the breeding sea- 
son is from April to September or even later. The young are produced in natural depressions under rocks, stumps, or weeds, or in shallow burrows made by other animals. When these are lacking, the female scratches a shallow hole under a bunch of grass or weeds, makes a nest of leaves or grasses and lines it with fur from her own body. Here the young, averaging in most of our species about four, are produced; they are fully furred and have their eyes open when born.

The female, while caring for her young, remains in the vicinity of the nest. If enemies approach, she runs away for a short distance; but when the young are attacked and cry out, she has been known to fight desperately in their defense, and even to vanquish such a formidable foe as a cat or a snake. When attacking, she jumps and strikes the enemy with her hind feet-members capable of a powerful blow, as many a boy who has captured a live rabbit can testify.

Young rabbits are attended and suckled in the nest for about three weeks, after which they are left to shift for themselves. Since suc- 
culent food is usually abundant, this is not a difficult task, and they soon adapt themselves to an independent life. Apparently the mother takes no further interest in the career of her offspring. The male parent is probably never concerned in the care of the young.

Injury to gardens and orchards. The cottontail is fond of frequenting farms and plantations, and having taken up its residence in some chosen fence-corner or thicket remains near it, feeding upon the succulent vegetables in the farmer's garden, or the clover, turnips, or corn in his fields. In the fall it feasts upon apples, cabbages, turnips, and the like left exposed in garden and orchard, and in winter, when all else is frozen hard or covered with snow, it turns its attention to twigs and bark of woody plants. The other rabbits have similar habits, varying with the environment. In the West some of the smaller kinds live largely in the abandoned burrows of prairie-dogs, badgers, and other animals.

Rabbits feed upon nearly all growing crops, but the damage to small grains is usually so slight as to pass unnoticed. Clover and al- 
falfa are favorites. In the Southwest they are quick to seize upon garden-patches, and in parts of Texas cantaloupes cannot be grown unless well fenced.

Rabbits, however, are most feared by treeplanters. They injure trees and shrubs in two ways-by cutting off the ends of branches and twigs, and by tearing away the bark, often until the tree is entirely girdled. The difference between the work of rabbits and that of field-mice may easily be detected by the large tooth-marks of the former, and by the height (16 to 18 inches above the ground) of the wound.

Newly planted orchards are especially liable to injury from rabbits, and few are now set out without provisions for winter protection from these animals. The losses of orchard and nursery stock in one neighborhood in Arkansas during the mild winter of $1905-6$ were reported at $\$ 50,000$.

Laws protecting the rabbit. In New England and the Middle Atlantic States the rabbit is protected, while throughout most of the West and South no restrictions are placed on hunt- 
ing the animals. In some Western States they are regarded with such disfavor that bounties have been paid for their destruction. ${ }^{1}$ In States where they are most abundant, protection is rarely afforded. In sections of the country where a close season on rabbits is accompanied by a strict enforcement of laws against trespass by hunters, rabbits have often become a nuisance.

On the whole, in America shooting has been the most effective means for keeping down the number of rabbits.

Ferreting usually is impracticable, since few of our native rabbits take refuge in burrows. Moreover, the use of ferrets is forbidden by

1 The bounty on rabbit ears paid by Gray County, recalls the bounty paid on gophers in Wallace and Greeley counties [Kansas] in 1894. The former county paid the bounty on scalps, while Greeley County paid it on gopher tails. The boys along the county line traded gopher tails for scalps, and realized 10 cents on each gopher. A five-cent bounty was paid on rabbit ears also, and rabbits and gophers were so plentiful that many families made their living from hunting. So much bounty money was claimed that Wallace County resorted to scrip payment, and this became so plentiful that its value dropped to 50 cents on the dollar. The eounty finally tried to repudiate the scrip, and in suits fought to the highest court, it succeeded after five or six years of expensive litigation.-Kansas telegram to New York Times, Jan. 2, 1911. 
law in some States which protect the rabbit. Coursing with greyhounds has many advocates and is popular in the West, where the swifter jack-rabbits abound. Smaller rabbits are often chased with fox-hounds, but the beagle is rapidly taking precedence as a favorite for rabbithunting, the gun being depended upon for securing the game. All of these are most exhilarating sports.

Where the country is sufficiently open for the purpose, one of the most successful methods of reducing the numbers of rabbits is the organized hunt, known as the "drive." This method has been tried in many localities in the West and in Australia with satisfactory results, the number of rabbits killed in a single drive reaching as high as 10,000 or even 20,000 .

Complete extermination of rabbits in any part of the United States is not desirable, as has been remarked, even if it were possible. In most cases where protection seems necessary a rabbit-proof fence may be cheaply constructed of wire netting, 11/2 inch mesh, from 2 to 3 feet high, with the lower edge sunk a 


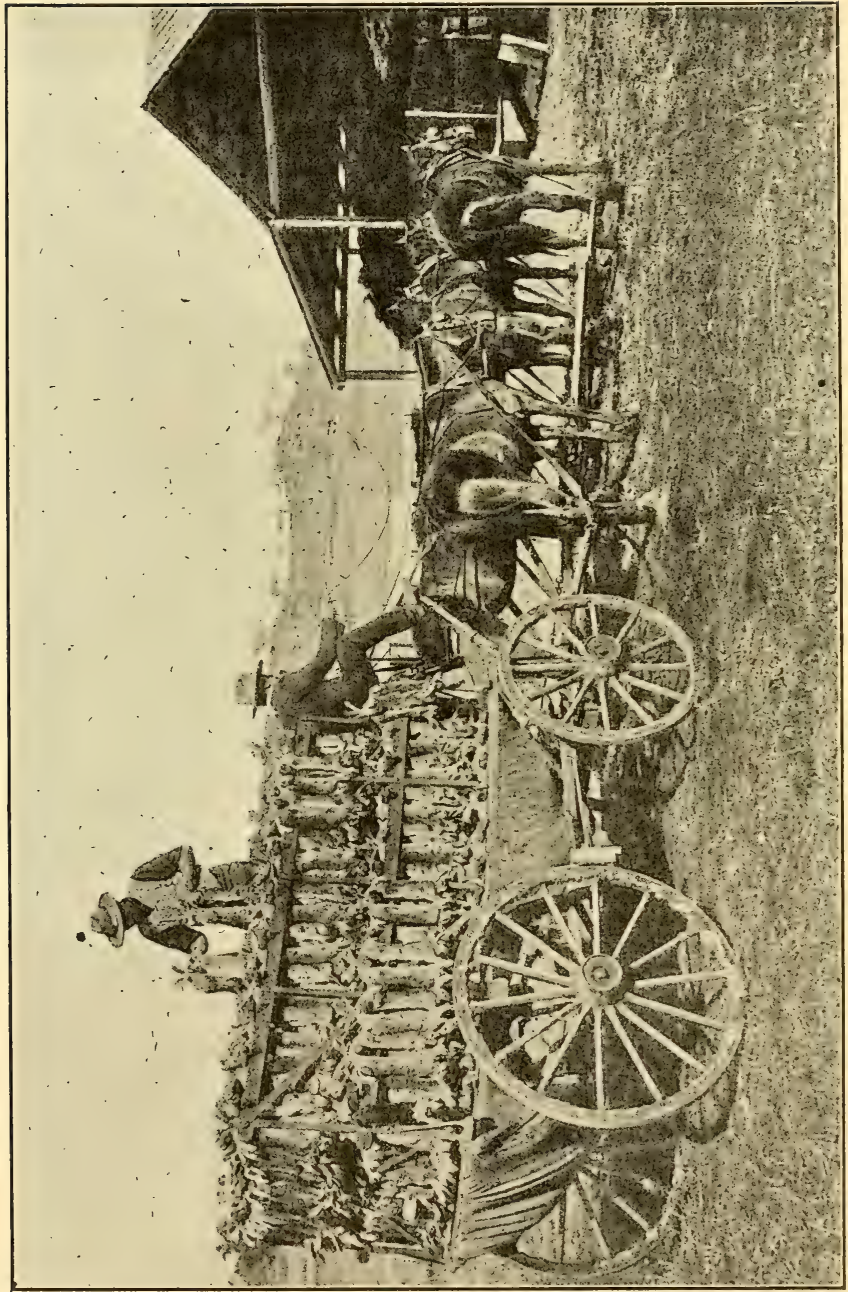


little, or a furrow plowed against it to prevent an occasional disposition to dig under.

Protecting trees against rabbits. The devices that have been recommended for protecting trees from rabbits are too numerous for separate mention. The majority consist of paints, washes, or smears supposed to be distasteful to the animals. Unfortunately, those that are sufficiently permanent to afford protection for an entire winter often injure or even kill the trees to which they are applied. Coal tar, pine tar, tarred paper, and various oils are likely to kill young trees. Blood and animal fats. when freshly applied will protect from rabbits, but are objectionable, since they are highly attractive to the destructive shorttailed field-mice. Carbolic acid and other volatile substances afford only temporary protection, and must be renewed too often to justify their use. Bitter substances, like commercial aloes, or quassia, are useless against rabbits.

Among the most promising washes that have been recommended for tree protection is the "lime-and-sulphur", wash, so effective in winter for the destruction of the San Jose scale. 


\section{ANIMAL COMPETITORS}

If this cheap method of controlling our worst insect pest of the orchard has further value in protecting trees from rodents, the fact can not

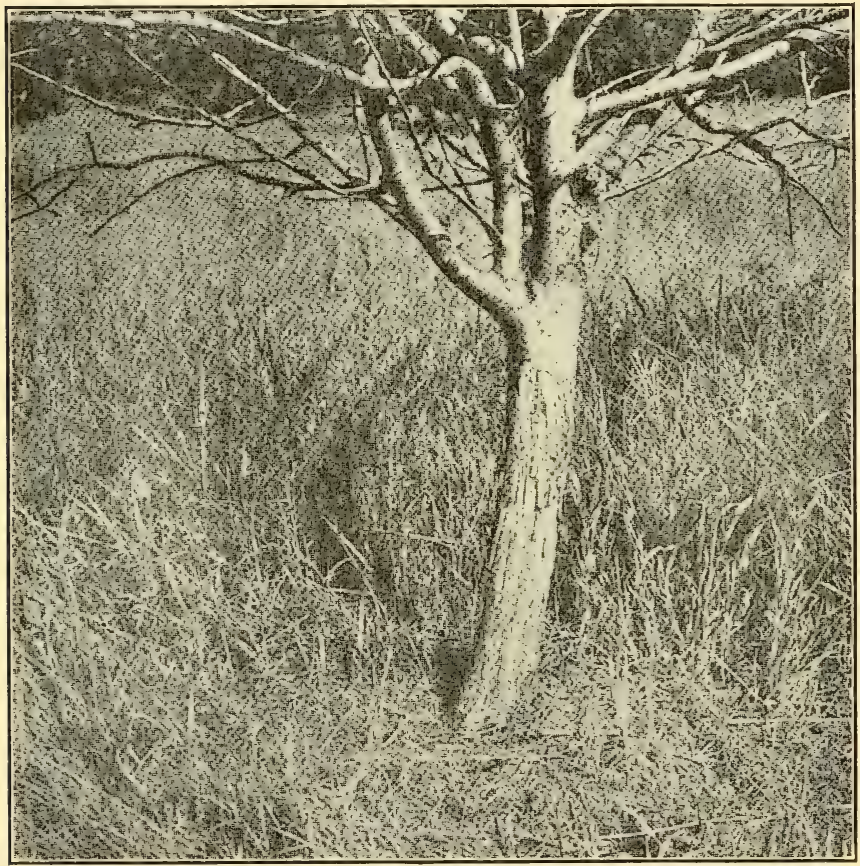

AN APPLE-TREE KILLED BY RABBITS.

be too widely advertised. The results of personal observation by the Survey seem to fully warrant its recommendation, and its cheapness 
makes the method worthy of general trial by orchardists.

The formula for the wash, reduced to the basis of the capacity of the ordinary kerosene barrel commonly used in the preparation, is:

Unslaked lime...........

Flowers of sulphur.......

Water to make...
20 pounds

15 pounds 45-50 gallons

A little salt may be added to increase the adhesive property of the mixture. The lime, sulphur, and about a third of the water are boiled together for at least one hour, and the full quantity of water is then added. For San Jose scale the wash in the form of a spray is applied to the entire surface of the trees. For protection from mice and rabbits the trunks only require treatment, and the wash may be applied with a brush. One application in November should last the entire winter.

Mechanical contrivances for protecting young orchard trees are many. The following are recommendations :

"Where protection from rabbits only is required, woven wire netting is recommended. This should be made of No. 20 galvanized wire, 1-inch mesh, such as is 
often used for poultry netting. For cottontail rabbits rolls 18 inches wide are recommended, but as a protection against jack rabbits wider material is safer. The wire is cut into 1-foot lengths, and one of these sections is rolled into shape about the trunk of each tree, the ends being brought together and fastened at several places by means of the wire ends. No other fastening is needed. The wire is not in contact with the trunk and may be left on the tree permanently. It will probably last as long as the tree requires protection, and the cost of material need not be over $13 / 4$. cents for each tree. For young evergreens, material of the same kind 1 foot wide and cut in $11 / 2$-foot lengths will give excellent protection.

"If trees are to be protected from both rabbits and mice, materials of closer mesh must be used. Wire window-screen netting is excellent for the purpose, and the cost, when permanence of protection is considered, is not great.

"Veneer and other forms of wood protectors are popular and have several advantages. When left permanently upon the trees, however, they furnish retreats for insect pests. For this reason they should be removed each spring and laid away until cold weather. While the labor of removing and replacing them is considerable, they have the advantage, when pressed well into the soil, of protecting from both mice and rabbits. They cost from 60 cents per hundred upward, and are much superior to building paper or newspaper wrappings. The writer has known instances where rabbits tore wrappings of 
building paper from the apple trees and in a single night injured hundreds of them. 'Gunny-sack' and other cloth wrappings, well tied on, are effective protectors. Cornstalks also furnish a cheap material for orchard protection. They are cut into lengths of 18 to 20 inches, split, and tied with the flat side against the tree, so as fully to cover the trunk."

\section{RABBITS AS PETS.}

It hardly falls within the scope of this book to treat the subject of rabbits as pets; but some brief directions for keeping them may not be amiss.

All the various forms of pet rabbits, including what is called the Belgian hare, are varieties of the wild European rabbit brought about by selective breeding in domestication. That under favorable circumstances they would thrive and multiply wild here, or in any temperate part of the world, is shown by the hordes of them which became a formidable pest in Australia. A vast amount of time and work and money have been expended in trying to get rid of them, and it has been found that the best plan has been to fence them out of the farm-lands and sheep-pastures where they 
were so undesirable. Lately, they have been turned to account as food, enormous numbers of their frozen carcases being shipped to Europe; and also great quantities of canned rabbit-flesh.

I am not aware that in this country any really wild colony has been permitted to grow except one near Belleville, Ontario, on a rocky point covered with cedars, which jutted into the Bay of Quinte. The increase in only two years was astonishing. Undoubtedly an enclosed space of waste land, where the creatures might burrow easily, if devoted to a colony would shortly produce a large annual crop for market with a minimum of expense and trouble; but whether regular sale for them could be found is another question which would depend for its answer largely on local circumstances.

A few years ago an effort was made by the Department of Agriculture to arouse an interest in breeding and eating the large variety, known as Belgian or Dutch hare, which originated in the Netherlands fifty or sixty years ago, but it did not succeed. These large rab- 
bits may still be purchased of dealers in pet stock, and are the best for practical rabbitculture.

Advisable for children. No pets are more interesting for young children than rabbits, and if attended to gently and properly they become very tame. The ordinary scrub is good enough to begin with; and after the youngster has learned the lesson of regularity and care in keeping and breeding them, he will want and may be trusted with fancy varieties, such as the lop-ear or angora, which are the aristocrats of their kind.

Hutches. Although the hutches may be built out of rough materials, such as an old box, it is a mistake to suppose that any sort of a kennel will do. The hutch should be tight and warm, protecting the animals well from rain, cold drafts and a burning sun.

Each hutch should consist of two parts,an inner and an outer compartment. The inner one, or bedroom, should be about $21 / 2$ feet square and high, and have a solid floor. It should also have a hinged door in order to permit of cleaning it, and also a little low door, 
or hole, giving access to the outer, or diningroom. This outer apartment should be somewhat larger and consist of a stout framework covered with chicken-wire on all sides, including the floor. Then, in fine weather, the hutch may be moved about the yard, and the rabbits will be able to eat the grass through the wire flooring; when the forage has been eaten in one spot, the affair may easily be lifted and set down in another. However, in wet or chilly weather, a board floor should be provided, either within or beneath the cage. Dampness and chill are always to be avoided; hence the roof ought to slant so as to shed water, and the hutch ordinarily be raised above wet ground by supports, such as a brick under each corner.

A few gimlet holes should be bored in the floor of the bedroom for drainage, and also near its ceiling for ventilation. Other than this there should be no windows or cracks, as it is necessary that this room should be tight and dark, like a burrow. Its only furniture should be a little dry hay, changed as often as it becomes soiled. The feeding and water- 
ing pans should also be kept very clean; and these ought to be of pottery or iron, as wooden ones are ruined by nibbling. The hutch should be cleaned regularly; in fact, it is a good thing to make a practice of raking out the refuse every morning and giving the rabbits a bed of fresh straw.

Rabbits should be fed regularly twice a day. Almost anything in the way of fresh vegetables is good for them-green grass, lettuce, cabbage-leaves, roots, such as carrots, sweet apples, and vegetable parings from the kitchen. A regular daily ration, however, should be a small quantity of grain, half oats and half bran, or something similar, and in the winter good hay. Many recommend in winter, warm tea-leaves and dandelion as an occasional treat, good for their health, and boiled potato-parings given warm. One experienced man warns us against giving cabbage-leaves to the young; and also warns us that all green stuff offered must be quite dry or it is likely to "pad" the animals-give them cholera morbus. They do not need much water when fed on juicy food, but drink a good deal when living on hay and 


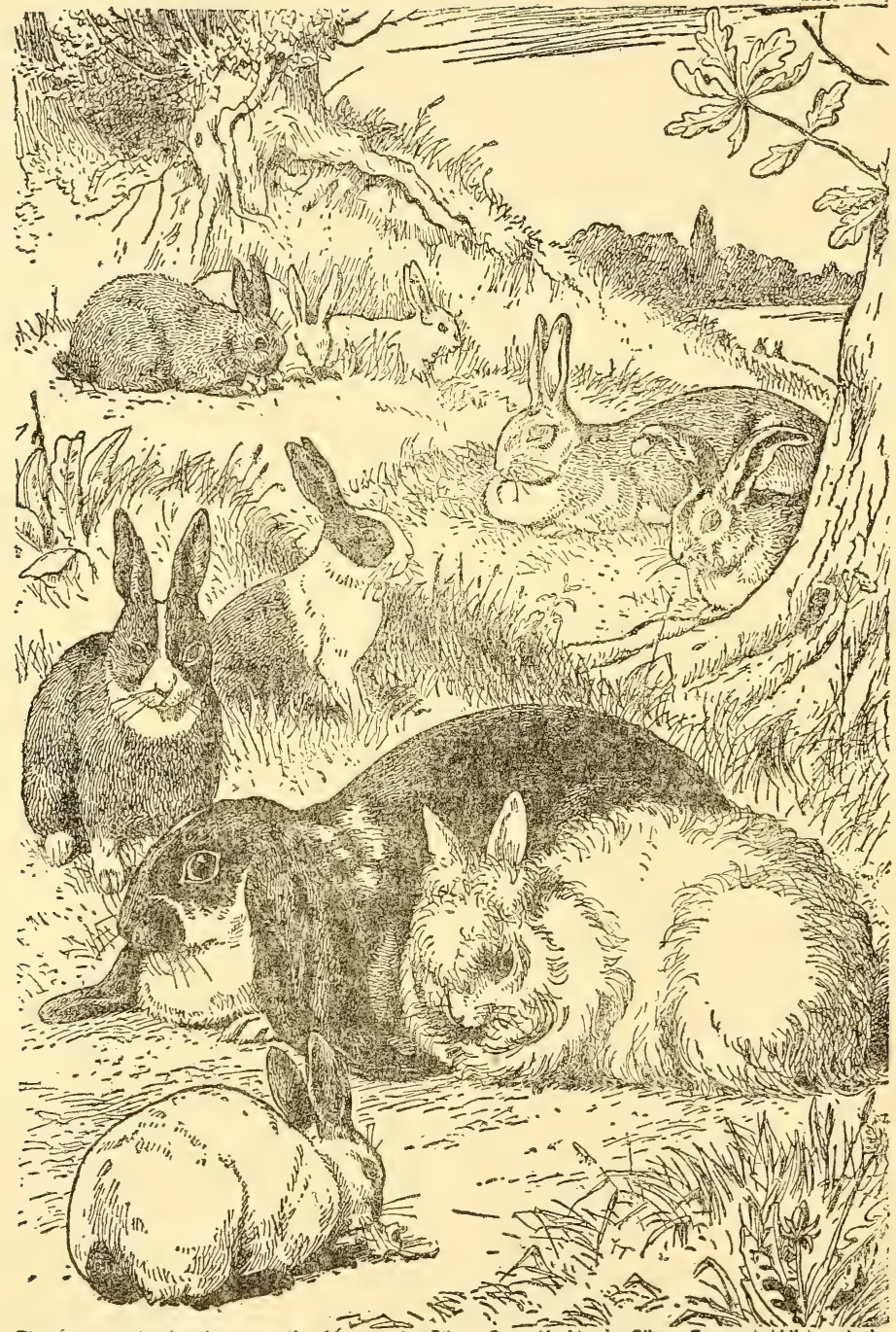

The three radoits together neat the fóp are the Silver Grey (dark), the Silver Cream (middle), and the Polish. The big rabbit with thb ears standing quite erect is the Flemish Clast, and the one next it, hlding behind the tree, is a Patagonian. INext come the two black-and-white rabbits, which are Dutch. The big rabbit with vers long ears is a lop-eared rabbit, and the white one beslde it is an Angora. The last is a Himalagan. 
shorts; and a supply should always be kept within their reach.

Directions for breeding. Rabbits will mate and breed every two months or so. When the doe desires the buck, as the male rabbit is called, she will announce it by stamping with her feet and behaving restlessly. The period of gestation is four weeks, and when the young are about to be born the mother will tear fur from her breast and form a soft bed for them. She should then be given a hutch quite to herself, and left undisturbed. Your curiosity will be great to see the little ones, but it is better to restrain it until, a fortnight later, they begin to be brought out for air. They mature rapidly, but should be left with the mother five or six weeks, unless she shows by fighting them away that she is weaning them earlier. The young should not be given as fresh, rich food as the old rabbits, but selected and somewhat dry and wilted food. The first litter is sometimes lost, by bad mothering, but rarely a second or subsequent one.

Rabbits are subject to various diseases, but these can usually be prevented by good care. 


\section{CHAPTER XI}

\section{SUPPRESSION OF RODENTS AS PESTS}

INTERESTING and beautiful as most of the rodents may be regarded, and beneficial to mankind in much of their work, there are undoubtedly many times and places when, owing to their excessive numbers and activity, they constitute a serious nuisance and must be suppressed.

Foolish destruction of rodents' enemies. Prominent among the recognized causes for the great increase of rodent pests in recent years is the persistent destruction of the birds, mammals, and snakes that habitually prey upon them. Even farmers have joined in the warfare against the so-called "vermin," and too often have sought to get ill-advised legislation against mammals and birds that are beneficial.

Among the wild mammals of North America known to feed upon field-mice and their burrowing relatives are bears, wolves, foxes, 
wildcats, all the weasel-tribe, and the brown rat, one of his few commendable traits.

Bears, the puma and the wildcats, foxes and wolves, all subsist largely on mice and groundsquirrels. Dogs frequently follow their masters to the field at plowing and harvesting, ready to pounce upon every mouse or gopher uncovered; and they sometimes become very fond of both the prey and the sport and hunt independently. Some cats are good mousers, and in places live largely on wild game; but unfortunately they also learn to destroy songbirds and game-birds, and their nests. The ordinary farm cat is a terrifically destructive animal, and when it develops hunting proclivities it should either be reformed, or belled or killed. Rats kill many mice, in the fields, as well as about houses, forcing their way into their burrows. Even the ferocious little shrews may do so, dashing fearlessly at one twice the shrew's size.

The weasel tribe the best police. The most efficient check upon the over-production of rodents, however, so far as mammals are concerned, is furnished by the tireless hunting of 
the skunks, badgers, minks, ferrets and similar animals of the weasel family,-albeit they do other things which are less pleasing to the farmer. The smaller weasels easily traverse the surface-runways of the larger species of Microtus, and even follow them into underground burrows. The larger weasels feed upon pocket-gophers, prairie-dogs, groundsquirrels, and various kinds of mice and rats. While occasionally they capture game- or songbirds, as well as poultry, their principal food consists of injurious rodents.

This general statement applies to minks, skunks and badgers, as we shall see when we come to speak of these animals more particularly; and nothing could be more unwise than to kill these animals or allow anyone else to kill them upon farm or ranch, except in the occasional case where one is known to have acquired the habit of taking eggs or poultry. In most cases the blame is placed on the wrong head. Almost all skunks leave birds entirely alone, as also does the badger, which in the gopher country ought to be protected with the utmost solicitude. It has been repeatedly no- 


\section{SUPPRESSION OF RODENTS}

ticeable that when white weasel-skins are high-priced, and, consequently, many of these animals are trapped in winter, the following season will be one of excessive mischief by all the smaller rodents.

L. C. Cummins, of Riverside, Cal., writing to the Biological Survey, February 12, 1892, says:

At one nursery we were bothered with gophers; all at once the gopher became scarce and from one to five weasels could be seen nearly every day running through the nursery stock and over an adjoining hill. They completely drove away and killed all the gophers.

Useful aid by birds of prey. A similar account might be made of the birds-not only birds of prey, of which the owls and the marshhawk are to be put foremost, but shrikes (butcher-birds), crows, jays, roadrunners, gulls and several of the heron tribe. Bitterns, egrets, cranes and the like, search steadily for meadow-mice. In California the great blue heron is protected on many ranches in realization of valuable service. A letter to The Pacific Rural Press, Oct. 23, 1897, from W. M. Bistoe, related that a neighbor found barn-owls had 
made their home in his pigeon-house. Thinking they were after the pigeons he shot the male and the next day trapped the female. On investigation he found four young owls in the nest, together with the remains of ten pocketgophers. He immediately released the captured mother, with his apologies. This owl is so regular in its daily capture of these pests that it might well be named the gopher-owl.

Serpents devour mice and gophers. Snakes must be included among the natural enemies of field-mice. The larger bull-snakes (Pituophis), blacksnakes (Callopeltis), and rattlesnakes (Crotalus) feed largely upon rabbits, prairie-dogs, pocket-gophers, and ground-squirrels, as well as different species of rats and mice. Blacksnakes and bull-snakes probably kill more field-mice than the others; but blacksnakes destroy also a considerable number of nestling birds and birds' eggs, so that part of their beneficial work is offset by this injurious habit. A nurseryman in Pennsylvania reports that he secured immunity from mice in his nursery by turning loose in it 50 blacksnakes.

The Pacific bull-snake (Pituophis catenifer), 
because of its habit of killing pocket-gophers, is quite generally called the gopher-snake. A writer in The Pacific Rural Press for May 12, 1888 , says of the reptile:

It is an act of insane folly to destroy them, for they are the most active and efficient allies of the nurseryman, farmer, and fruit raiser in the destruction of those most pernicious pests, the gopher and the squirrel. They destroy more gophers than all the appliances that man can bring to bear in the shape of traps, poisons, and gases.

On the whole, snakes, except the venomous species, are deserving of the farmers' protection. Like the toad, the smaller kinds feed almost wholly upon insects; but an inherent prejudice induces thoughtless people at every opportunity to destroy these friends of agriculture.

Poisoning and fumigation. Undoubtedly the most effective methods of getting rid of rodent pests of all kinds is by poisoning them, and by trapping them. Directions for doing this applicable to the various kinds will be found in the last chapter, and need not be dwelt upon here. 
Fumigation is a method of despatch which has proven effective with prairie-dogs and ground-squirrels, but is of little use in the case of gophers or moles, because the latter dig so fast and so quickly close their tunnels against the fumes as to escape its effects. Machines have been invented for blowing the fumes of burning sulphur down the burrows. Better results, however, are gained with carbon disulphide. This is an antiseptic liquid which may be bought in quart-bottles, and is very useful in general for killing vermin, protecting stuffed birds, etc., in museum cases or in boxes, and similar purposes; but must be kept away from fire as it is easily inflammable and explosive. It evaporates rapidly, making pungent fumes in a closed place. The method to be used is to carry it, corked, to the mouth of a burrow, pour a small quantity upon a little wad of rags or corn-husk, or a ball of horse-dung, and push it quickly as far as you can down a burrow and immediately close the entrance with packed earth. Unless the soil is very dry and the burrow extensive the animals at home will be smothered. In the case of prairie-dogs, the 
field should first be gone over with poison, and the bulk of the animals thus destroyed.

Flooding the burrows. Where available, water is one of the best means of combatting pocket-gophers. Flooding the land in winter is especially effective, as it wets the animals and drives them to the surface, where they soon succumb to the cold. In warm weather the method can be made effective if men and dogs are on hand to kill the animals as they seek refuge on the embankments. S. E. Piper, of the Biological Survey, reports that about the middle of April, 1909, at Modesto, Cal., he saw some boys killing pocket-gophers that had been driven from an alfalfa patch by flooding. A hundred gophers, more than half of them young of the year, were killed from a three-acre tract.

Difficulties of extermination. Much hope has been entertained that a bacterial disease fatal to rodents, and particularly to rats, might be found, but thus far has been disappointed. It was thought that a bacillus (B. typhimurium) given to the field-mice which over-ran Thessaly in 1892-3 had put an end to the plague, but it is now thought it did little to 
hasten the end. Experiments with similar organisms have been reported successful since in Russia and in France; but none of the like attempts made during the mouse-plague in Nevada in 1908 had an appreciable effect.

\section{As Mr. Lantz says:}

"The destruction of noxious mammals is a more complicated problem than that of insect destruction. The farmer who fights these higher forms deals with instincts and intelligenee well adapted to cope with his own in the struggle for existence. It is not enough that he place poisoned food or traps in the way of the creatures he desires to destroy; he must make the baits attractive and allay the natural suspicion of the animals by ridding traps of all suggestion of their real nature. He must know the traits of the animals and take advantage of any habit that will enable him to circumvent and destroy them."

\section{Furthermore:}

"In warfare against any rodent pest little permanent good can be accomplished except by coöperative effort. Although it always pays the individual farmer or fruit grower to exterminate pocketgophers from his own lands, yet if he can not secure coöperation of the whole community he must constantly guard against a return of the pests and be ever ready to renew offensive operations against them. 


\section{SUPPRESSION OF RODENTS 193}

With united effort the animals can be completely exterminated over entire townships, or even counties, and when this is accomplished immunity from the pest will continue indefinitely." 


\section{CHAPTER XII \\ MOLES, SHREWS AND BATS}

UNDER this caption might be written a long list of American insectivores,-animals which are to be thought of not merely as feeding upon insects, but as belonging to the Order Insectivora. This order is a group of small, slender, plantigrade animals, having fine sharp teeth and digestive organs especially suited to a diet of worms and insects. They are found all over the world, except in South America and Australasia; and are of particular interest to the zoölogist because much evidence allies them with the earliest known type of mammal, so that the insectivores seem to represent, with little alteration, the most ancient mammalian stock. They are most nearly related to the lemurs and the bats.

The moles under the lawn. Our insectivores are all small and inconspicuous, and popular interest is attached only to the moles 


\section{MOLES, SHREWS AND BATS 195}

which disfigure our lawns and flower-beds. It is commonly believed that the mole bites off roots and eats such things as lily-bulbs and sweet potatoes; but all the harm it does is now and then to upset a plant or disarrange a bit of grass-plot. It is in search of worms, grubs and burrowing insects, that the mole pushes his way beneath our feet; and he devours a vast number of these, which do prey upon the roots and stems of grasses and other plants. The real mischief occasionally observed is due to the field-mice which sometimes follow his track.

The mole has become extraordinarily well fitted for his underground work. His body is a loosely filled sack which will stand a lot of bending and squeezing, and his head is like a round wedge with a flexible point,-really an exquisitely sensitive nose and a mouth filled with capable teeth. Within that sack are the most massive shoulders and forearms for their size in the animal kingdom, the latter terminating in broad, strongly webbed hands, armed with long, sharp claws, like a shovel ending in five pick-blades. These great hands are twisted so that their palms are outward, thumbs down, 
and the thumb is braced by an extra wristbone, and armed with a horny outgrowth of skin with a knife-like edge. The accompanying muscles are enormous. As the creature goes through the soil he stretches these instruments ahead of his nose, drives the claws into the soil, then sweeps them outward, and so progresses by a swimming motion, kicking the loose soil behind him, and now and then throwing' it out upon the surface in a "mole-hill.",

The strength required for this is prodigious, as may be tested when a mole is placed among movable objects. Godman describes one which, after a fall from a mantel-piece, hurried to the wall and then began to travel around the room.

"Whenever," he says, "its course was impeded by the feet of the chairs, which were of large size, it would not go around them, but wedging itself between them and the wall, pushed them with apparent ease far enough to obtain a free passage, and it thus continued to move several in succession. What was more astonishing, it passed in a similar manner behind the legs of a small mahogany breakfast table, and pushed it aside in the same way it had done the chairs, finally hiding itself behind a pile of quarto volumes, more than two feet high, which it also moved out from the wall." 


\section{MOLES, SHREWS AND BATS 197}

Dr. Merriam worked out the dynamies of this last feat, and found it equivalent to a man's exerting a pressure of 12,000 pounds!

Methods of the gurden mole. In loose old cultivated ground, where earthworms and grubs are numerous, moles travel in every direction just beneath the surface, and often never return on their tracks; but many of their subter'ranean paths are regular galleries or runways, intersecting with others and centering in a home nest which seems to be occupied year after year, and often by several pairs or families. This nest and the runways are kept in excellent repair. "When the shrew-mole encounters a rock or an old log, or stump, in the course of his subterranean wanderings," remarks Merriam, "instead of avoiding it he takes great pains to burrow beneath, making extensive excavations in contact with its under surface. The reason is obvious, for he knows . . that in such places are to be found many slugs, ants with their egg's, and other tender insects."

As winter comes on the mole sinks below the frost-line, as do the earthworms, and so pur- 
sues its prey at a safe depth. It does not hibernate but is much less active than in summer, and doubtless is made so drowsy by the chill and the scarcity of air beneath the frozen topsoil that it sleeps most of the time. In summer these little creatures have a curious habit of coming to the surface precisely at noon, and peering out, or even taking air and sunshine in a little walk. They are not blind, but their eyes are hardly larger than mustard seeds, so that vision must be restricted to little more than the perception of light.

A closely related but smaller northeastern species is Brewer's or the hairy-tailed mole; and the Pacific coast has Townsend's and other species.

The mole with the rosette. The star-nosed mole is a very interesting one, common in the Great Lakes region and on the Atlantic slope. It is larger than the garden mole, has a longer tail, a blackish-brown coat impervious to water, and particularly a rosette of pinkish fleshy feelers around the end of its pig-like proboscis. It lives by choice in swamps and wet meadows, where its burrows often open in some stream- 
bank below the water. It can swim and dive excellently, and no doubt adds to its fare of worms and grubs many small creatures and their eggs caught in the water and on the stream-bed. It seems to be more active in winter than the others, frequently moving about under the snow or on its surface.

Moles are hardy, easily tamed and supported on shreds of meat, and exhibit intelligence as well as an ugly temper. When two or more are confined together the murder and eating of the weaker is likely to follow, until one cannibal is left.

Shrews and their ways. The shrews are relatives of the moles, which do not tunnel, but are so small, secretive and nocturnal, that few persons suspect their presence, although they are numerous and of many sorts all over the country, even very far to the north. Our eastern long-tailed shrew is the smallest known mammal and could curl up in a. walnut husk, yet it exists at the Arctic Circle and runs about in the snow of a Canadian winter. They are mouse-like animals, extremely swift and agile in their movements, but instantly separable 
by their long, flexible, trunk-like noses, bewhiskered noses, minute eyes and ears, and red-pointed teeth, which, of course, are not in the least like those of a mouse. As I have written elsewhere:

"All the shrews are ceaselessly active, wandering about underneath leaves, old grass, and logs, and boring their way into loose loam or the punky wood of decayed stumps, in search of earthworms, grubs, beetles, slugs, and similar prey, including young mice and the fledglings of ground-nesting birds, and varying this fare by bites from soft-shelled beechnuts, tuberous roots, etc. They are astonishingly quick of hearing; are bold, pugnacious, and fierce, often killing and eating other shrews; difficult to keep alive in captivity, utterly untamable, and easily frightened to death. All kinds exhale from glands near their armpits a musky odor which no doubt is protective, since most hawks, eats, foxes, etc., do not eat them unless excessively hungry; but owls and weasels appear to be well pleased with such flavors, and eatch and devour them in large numbers."

We have a large number of shrews, some of which are aquatic, and the variety of color and size is considerable. Cuba and Hayti each also possesses a large sort of insectivore, called almiqui and looking like a shrew as big as a rat. 


\section{MOLFS, SHREWS AND BATS 201}

Little is known of the habits of either, and they are chiefly notable because closely related to certain insectivores of Madagascar, the tenrecs, indicating descent from a common and extremely primitive source, as the only explanation of their now living in two so widely separated regions.

American bats. These insect-eating mammals of the air constitute a distinct group (Order Chiroptera), characterized by the possession of leathery wings, and other features which separate them from the terrestrial insectivores. North America has about twenty species, nearly all of the world-wide family Vespertilionide, in which the nostrils are without those membranous appendages called a nose-leaf, and the ears are of moderate size and shape. On our southwestern border, however, occurs a true nose-leafed, fruit-eating bat or two, representing families numerous in Mexico, Central America and the West Indies, to one of which belongs the dreaded vampire,-the blood-sucker of equatorial South America. Most of the North American bats are confined to the warm South, but half a 
dozen kinds are spread all over the Northern States and southern Canada, some regularly migrating southward in winter and returning in spring like birds.

The commonest ones are the little brown bat, which is glossy brown above and paler below; the very similar, but more southern pipistrelle; the silvery bat, whose fur is dark brown with white tips; and the rusty or foxy-gray red bat. All these are small (3.4 to $4.4 \mathrm{in.}$ long). A larger dark brown kind, the Carolina bat (4.6 in.) is common in all the Southern States; while the North has the big hoary bat (5.4 in. long, grizzled above, white below), a longwinged, swift-flying denizen of forests, rarely seen and a winter migrant. Other species are locally well known in California and along the Mexican border, especially the little "freetailed", Texan bat (Nyctinomus), which represents a tropical group in which the tail is free from the membrane stretched between the hind legs.

All these bats are similar in habits, sleeping in some dark and sheltered place during the day, and hibernating more or less completely 


\section{MOLES, SHREWS AND BATS 203}

in winter. At twilight they come squeaking out to hunt in swift zigzag flight for small flying insects, thus destroying hordes of gnats and mosquitoes; and in the early morning they take another meal before disappearing. In this business their sharp eyesight is aided by an inconceivably delicate sense of touch in their wings and elsewhere. Where caves or rocky crevices abound they often cluster on their walls in great numbers, or elsewhere throng in hollow trees; but they are quick to resort to buildings, finding their way into barns, garrets, broken eaves, belfries and like places, and sometimes becoming a nuisance by their noise and dirt and abominable smell, but otherwise they are harmless. The superstitious fear of them felt by some persons is only a part. of the nonsense that has come down to us from the Dark Ages, when all nocturnal animals were supposed to be somehow connected with the socalled "powers of darkness.",

The bats breed annually, usually producing twins in early summer, which are born naked and cling to the mother's body, where they may be suckled wrapped in her wings as she hangs 
head downward in her dark retreat or carried safely as she flies abroad. Extreme care and affection are shown by the little mothers, and their babies are long dependent upon them. No animals seem to prey on our bats, but they are quarreisome and pugnacious among themselves, and captives are not easily tamed.

Relations to humanity. Bats are not of much economic interest in this country-not as much as in the eastern tropics, where it is quite impossible, in some places, to raise soft tree-fruits unless the trees are carefully and strongly screened against the big fruit-eating fox-bats. Our species, on the other hand are wholly beneficial in their feeding habits, from our point of view, because their fare consists wholly of flying insects, most of which are in some way injurious or annoying to us. It is delightful to watch their dancing flight in the twilight--the more so when we try to count the number of mosquitoes they catch; and it is perfectly foolish for any one to be afraid of them as some women and girls pretend they are. It is also charged that they carry bedbugs and introduce them into houses. In common with 


\section{MOLES, SHREWS AND BATS 205}

most animals the bat acts as host to a few small insect parasites, one of which is a relative of the bedbug and somewhat resembles it. It is possible that at rare intervals one may be found carrying' a true bedbug', which is not one of its natural parasites, and might drop it in some garret; but the danger from this is slight.

Bats are naturally cave-dwellers, and certain caves favorably situated in wild regions have been tenanted by them in enormous numbers and for an untold length of time. In such caverns, discovered in various parts of world, thick deposits of guano have been found, and have to some extent been utilized, being exceedingly strong in nitrogenous elements and unimpaired, in their protected situation by the washing away of the soluble elements in which their virtue largely lies. 


\section{CHAPTER XIII \\ FOXES AND FOX-FARMING}

WE have in North America several different sorts of foxes. The red fox is the most widespread and important of these. A large form of it dwells in southern Alaska, and another variety, or species, is peculiar to Newfoundland. Then, in the West, are two small foxes, the kit or swift fox of the central plains, and the big-eared swift of southern California and Arizona.

The kit-foxes of the west. These last are handsome grizzled-gray and yellowish little animals, with keen, interesting faces, tall, alert ears, and the ability to run like a streak. Each has a full measure of the cunning of its harried race, and makes a good living during all the warmer half of the year at the expense of mice, spermophiles and gophers, but in winter, when most of these are safe under ground, it must have a harder time, and resort to various foxy 
FOXES AND FOX-FARMING 207

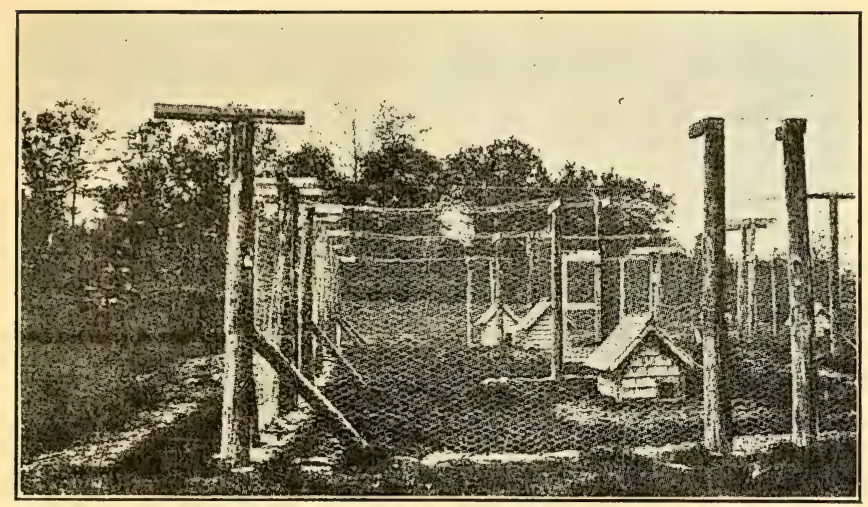

YARDS, WITH FOX-KENNELS.

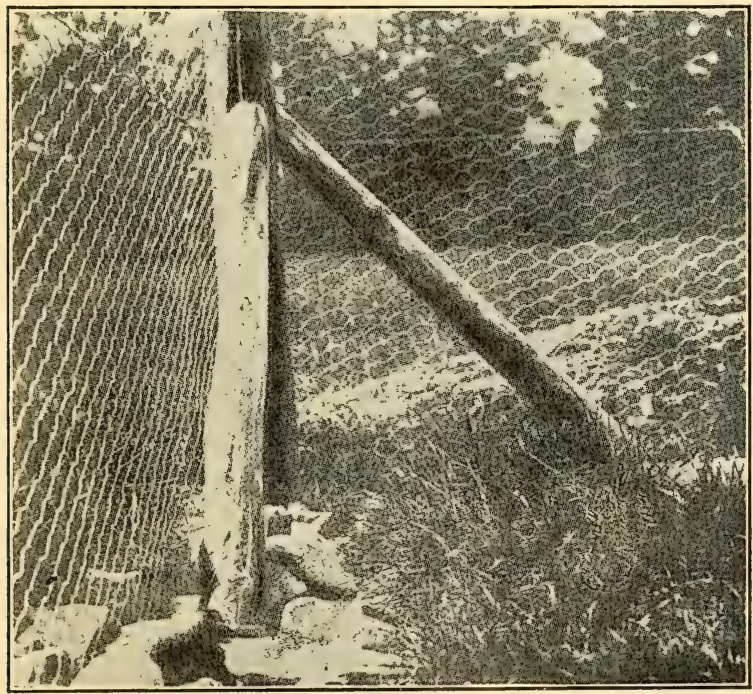

A CORNER, WITH STONES TO PREVENT THE FOXES DIGGING OUT. 
tricks to catch snow-birds and grouse, especially in the far North.

It is quite harmless to man, and would probably increase rather than diminish as ranching and civilization gradually overspread its once lonely haunts, did it not so often fall a victim to the poisoned baits laid out for coyotes. This is unfortunate, especially in prairie-dog regions, for it is an indefatigable and skillful hunter of these troublesome burrowers.

The gray fox. Throughout the Southern States occurs a rather small fox differing in color,-for it is prevailingly gray-and also in habits, from the northern red foxes. This gray fox seems to have less sharpness, adaptability and fearlessness than the red; and it is also less fecund, its young rarely exceeding four or five annually, whereas the litter of the red often numbers seven or eight. Otherwise the gray fox seems to have several advantages, as I have pointed out in my Life of Mammals:

"It is decidedly smaller and less conspicuous, being silver-gray, darker on the back, and tinged with rufous on the ears, sides of the neck, breast, and under parts, while the tips of the ears, top of the nose, 


\section{FOXES AND FOX-FARMING}

chin, and feet are black. It is a woodlander, and seems incapable of adapting itself to the cleared districts in which the red fox so easily makes itself at home; climbs trees almost like a cat, and takes to them naturally for safety or to get grapes and persimmons to eat. There, too, it makes its home in a hollow stump or log, not digging a burrow, for the weather of its southerly habitat, and the later date of its breeding, do not require for its young the warmth of an underground nursery; and all the year round it can supply itself with food by its own cunning tricks, while the red fox must wander over many miles of country. The ground-breeding birds and waterfowl and their eggs form its principal fare, perhaps in summer, when hens or turkeys straying in the woods are likely to be seized; but rarely is the poultry disturbed on the home roost, nor can such worse depredations as killing young pigs, lambs, etc., be laid at its door. Audubon, whose account of this to him very familiar animal is circumstantial, speaks of it as a 'pilfering thief' and of the red fox as a 'daring and cunning plunderer.' Gray foxes will run before hounds only a short distance, doubling constantly and for a short time, when they either 'hole' in a tree or climb one; while a red fox may run straight eight or ten miles away and then back in a parallel course.

"Extremely interesting is the arctic fox, of the polar regions right round the world. It is a shy, swift little beast with blunt nose, short rounded ears, a very long bushy tail, and the soles of its feet well 
shod with moccasins of hair, giving them a firm hold on the slippery rocks, snow, and ice, over which it leaves its tiny tracks from Labrador to the Lincoln Sea. Every arctic explorer from Steller down has had much to say of this animal, the accounts given by Richardson, Feilden, and Nelson being especially full and good. The most remarkable feature of its history relates to its varying phases of coloration. During the short aretic summer its dress is brown with the under parts lighter, often drab. In autumn this coat is replaced by one of pure white, beneath which is a fine wool; and this warm, white dress, invisible against the snow, is the normal winter hue of the great majority of arctic foxes. A small proportion, however, are never either white or dark brown, but are slate-gray all the year round. This double phase may oceur anywhere, one or two, perhaps, arising from a litter that becomes white; but in some rather southerly places the 'blues' prevail, forming a local race. Such is the case in Greenland, Iceland, and in the Aleutian Islands, where blue foxes are now carefully preserved and cared for in a semidomestic condition, for the sake of their highly valuable fur, a certain number being killed annually.",

The American red fox. Returning now to the common or red for, it appears that this is one of the most widely distributed of animals, for it is hard to distinguish more than such 
local varieties as might easily arise in different climates and from local peculiarities of food throughout the whole northern world. It is convenient to name them as species, but it is practically the same "Reynard the Fox" right around the globe.

"Our American form," to quote again from my Life of...Mammals heretofore mentioned, "seems especially variable since its typical yellowish red, darkest on the back and shoulders, may be very bright or very pale; or may have the markings on the spine and withers very dark and distinct, making it a 'cross fox,' or be totally black with a white-tipped tail; or black, with the tips of most of the hairs white, giving the fur a frosted or 'silver' appearance. . . .

"Foxes everywhere are naturally burrowers and nocturnal hunters of ground-nesting birds from ducks and geese to sparrows, and of their eggs; rodents of every sort, frogs, lizards, insects, and in summer and autumn fruit and berries. Some of the prey is got by running it down, for the fox is fleet; some by digging it out of its underground holes; some by stalking it with crafty caution; some by lying apparently dead until the victim approaches near enough to be seized by a catlike pounce. These are the essential tactics of its food getting in all lands, the fare and the method varying with the country; and endless stratagems match the native precautions of the small quarry. All the larger cats and wolves are its 
enemies in the wilderness, and the skill in avoiding them inherited from innumerable ancestors serves it well when in civilized lands the fox finds troops of dogs set upon its track.

"Standard works are supplemented by admirable essays on the American fox by Thoreau, Burroughs, Lottridge, Robinson, Seton, and others who know him well; none is more complete and intimate than the history given by Mr. Cram, who asserts that in New England, at least, the foxes in cultivated districts are far more highly developed in intellect than are those of the outlying parts, or than were the foxes of a century ago. They are the most bold, skillful, and inveterate of poultry thieves, and will sometimes take as many as 'thirty pullets in a single night'; and often half or more of the booty of such a raid will be found in a pile in some hiding-place, which goes to show that the foxes of all cold regions probably store surplus food. In return for levying upon his chickens (or, in Europe, upon the pheasants and other treasures of the gamekeeper) the animal aids the farmer by destroying numberless rats, mice, gophers, and similar pests."

Value of fox fur. Of all the products derived from wild animals furs are the most useful and valuable. Indispensable to primitive man, they are scarcely less important to the most civilized, for in warmth, beauty and durability, no manufactured fabrics excel them. 


\section{FOXES AND FOX-FARMING}

But expanding civilization is steadily diminishing the supply of furs, and the animals which bear them are proportionately decreasing, especially those whose coats are of high quality. The growing demand may be met partly by stricter enforcement of the game laws, but it is evident that it is becoming necessary to propagate fur-bearers in confinement, and by this means an important and new industry will presently be developed. This has already been the subject of no little thought and experiment, but mainly in reference to the smaller and less valuable animals, such as skunks and minks, as we shall see. Results of considerable importance have been obtained recently with Alaskan blue foxes, and a good deal has been done quietly in experimental cultivation of the Canadian silver fox.

This last industry has recently been made the subject of official investigation by Mr. W. H. Osgood, of the United States Department of Agriculture, from whose report the present article is mainly compiled. More persons have engaged in it than the public generally is aware of, for they have been disposed to keep their 
experiments quiet and their results a secret; but a recent investigation pursued by W. H. Osgood of the Biological Survey has gathered many facts as to method, of which I shall avail myself liberally.

Variability of the red fox. The common fox, as has been said, varies from red to black, and these extremes, with the gradations between them, form four more or less distinct phases, respectively known as red, cross (or patch), silver, and black.

In the red phase the animal is entirely rich fulvous, except restricted black markings on the feet and ears, a white area at the end of the tail, and certain white-tipped hairs on the back and rump. From this phase to the next the black increases in extent until, in the typical "cross" fox, the black predominates on the feet, legs and underparts, while fulvous overlying black covers most of the head, shoulders and back. A gradual increase of the black and elimination of the fulvous, or its replacement by white, brings us to the next phase, the "silver," or "silver-gray," in which no fulvous appears, the entire pelage being dark at the base 
and heavily or lightly overlain with grayishwhite. Silver foxes vary from those in which the color is entirely grizzled to those in which it is entirely black, except a few white-tipped hairs on the back and rump. Finally, in the black phase, the white is absent from all parts except the tip of the tail.

The red phase is much more abundant than the others, but the three interbreed freely, and wherever one occurs occasional examples of the others also may be expected. In general, the cross fox is fairly common, the silver-gray is comparatively scarce, and the pure black is excessively rare. The prices usually paid for skins of the different phases vary according to the relative scarcity of the animals. Thus red skins command only a moderate price ( $\$ 1.50$ to $\$ 3.50)$, cross foxes are somewhat higher $(\$ 4$ to $\$ 8)$, silver foxes are several times higher (\$50 to $\$ 250$ ), and pure black skins are exceedingly valuable, being higher priced than any other fur except sea-otter- $\$ 1,000$ to $\$ 2,000$.

Area suited for fox-farming. The natural habitat of this fox includes the greater part of North America, from the central United States 
northward to and including the border of the treeless tundra. The red phase inhabits nearly all this region, but the silver phase, although known in most parts of it, is very irregularly distributed. In general it is much more common in northern localities than in southern, and seems especially numerous in Newfoundland and on the interior heights of Labrador. Altogether, it appears likely that the area suitable for rearing silver foxes successfully is confined to Canada, and a small strip of country south of it, including the higher parts of the Alleghenies. Prince Edward Island has already about 100 breeders, and can supply good breeding-stock.

Arrangement of breeding-quarters. It is a mistake to suppose that a great space is required for rearing silver foxes, or a rough area approximating natural conditions of fox-life. Indeed, this is disadvantageous, for it tends to keep the animals so wild as to be unmanageable. The endeavor should always be to tame the captives as much as possible, and to do this a small and uniform area is necessary. Foxes thrive in enclosures not more than 40 feet 
square. These may be but a few rods from a farm-house, or, if visitors are excluded, in a quiet place on the outskirts of a village. A half-acre will accommodate about six pairs of foxes, which is quite as many as a beginner should attempt to handle. The selection of ground may depend upon circumstances, but effort should be made to include a few trees or small shrubs. These afford shade and a feeling of seclusion and security to the animals.

Inclosures for foxes are made with wovenwire fencing, but the mesh should be not greater than 2-inch, for young foxes are able to wriggle through an opening three inches square. The fencing should be about 10 feet high and sunk into the ground two feet. The foxes try to escape, when first placed in the pen, by digging at the edge of the wire, and abandon the effort when they find themselves stopped near the surface. The top of the fence, however, must have an inward overhang of two feet to prevent the animals climbing out.

Form of enclosures. In the arrangement of sub-divisions the general plan should conform to that shown in the accompanying diagram. 
Tlere a wide outer court is provided, separating the smalle: enclosures in which the foxes are actually kept from the unfenced area possibly

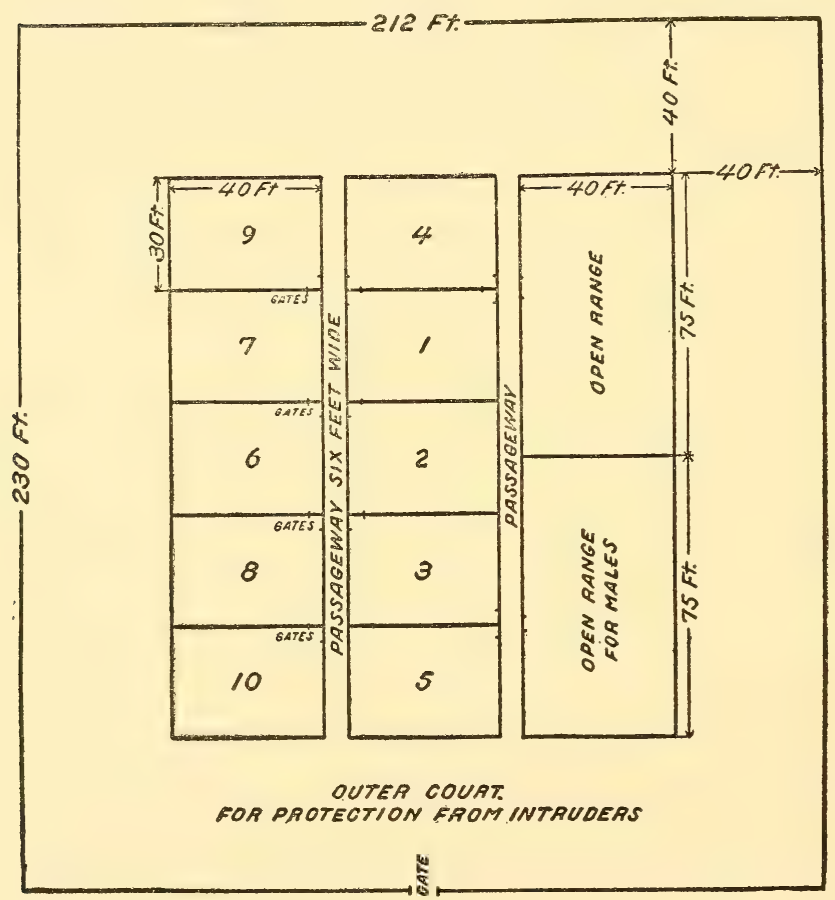

PLAN OF FOX-BREEDING ESTABLISHMENT.

open to the public. The court shown in the diagram is only 40 feet wide, but it might well be much wider, since its object is not so much 
to give additional security as to prevent curious visitors $01^{*}$ stray dogs, etc., from annoying the foxes. Seclusion, indeed, is of prime importance, hence no one ought to be permitted inside it except the regular keeper, to whom the prisoners are accustomed. Any means which will effect the desired seclusion, as hedges or a high-board fence, may be used instead of this outer wire enclosure.

The inner enclosures are of two kinds, most of them small and designed for single animals or pairs, but one or more are larger and intended to accommodate a number of foxes at one time. Every compartment should be provided with doors so arranged that animals may be transferred from one to another readily. The beginner with only one pair of foxes may start with two of the small compartments, and add others as needed, keeping in mind a convenient general plan. The small compartments should be at least 30 feet square. Those shown in the diagram are 30 by 40 feet, and the larger runs 75 by 40 feet. Passageways giving free access to all the compartments should be 4 to 6 feet wide. 
Each compartment should contain a small house or shelter-box, for, although the foxes often dig natural dens in the ground, they usually accustom themselves readily to artificial shelters. A common form of these is much like a dog-kennel and about the same size. They are ordinarily made four or five feet square and two or three feet high, with an entrance about six inches square. No nesting material is needed inside the boxes, as the old foxes either do without or provide themselves from refuse in their enclosure.

Foxes easy to keep. The mere keeping of foxes in confinement is a simple matter. They do not, as a rule, however, become very tame, even after several generations. They seem contented and happy in their cages, and rarely make determined efforts to escape. Several cases are recorded where captive silver foxes, having climbed out of their enclosures in winter, when high drifts of snow gave them a chance to reach the top of the fence, have returned voluntarily to their home.

Although in general suspicious of mankind and inclined all their lives to snap at or bite 
even their best known and kindest attendants, these foxes do not quarrel much among themselves, especially where properly fed.

So far as known, fatal disease has been so rare as to be negligible in any general consideration of fox-raising. Here and there an animal has died of some unknown internal complaint, but no particular disease has manifested itself. Nothing in the nature of an epidemic has thus far appeared, and even minor diseases have been exceedingly few. Fleas occasionally have proved troublesome, and, no doubt, foxes may contract mange and other diseases to which dogs are subject, but if kept in cleanly quarters and fed properly they are reasonably safe.

Cold weather has no terrors for them, and they delight in snow, but should not be permitted to lie upon it when it is alternately freezing and thawing, as their fur, by freezing to the crust and then being torn loose, will be injured.

Food and feeding rules. Wild foxes eat a great variety of food, including mice, rabbits, birds, and insects, such as grasshoppers, crick- 
ets and beetles. At certain seasons berries are eaten in large quantities. Meat, therefore, is only a part of their natural diet, and if fed exclusively is likely to have ultimately a bad effect. It is much better to supply the foxes with a mixed diet, including, besides meat, such food as bread, milk, table-scraps or dog-biscuits, all of which are relished. There is less danger in any particular food than in too large quantities at irregular intervals. Over-feeding produces fat, sluggish animals, that do not breed well, and it has been responsible for some expensive failures. The normal weight of a for is from six to nine pounds, so animals weighing over ten pounds are too fat. A regular daily ration is the proper method, both for the sake of their stomachs and because it tends to a more constant and friendly relation between the keeper and his charge. It is a good plan, nevertheless, to give them bones with little meat on them, now and then, upon which they may gnaw indefinitely. Occasionally they may be regaled with tidbits consisting of small wild mammals, as rabbits, woodchucks, rats, mice and other animals likely to be captured 
about the farm. Fresh drinking-water, of course, should be supplied regularly. If a spring or other natural supply can be included within the yards much labor is saved.

A daily allowance for each fox, according to the experts consulted by Osgood, is one-fourth of a pound of meat and a small handful of miscellaneous scraps. One of the most successful breeders feeds a quarter of a pound of meat and a quart of skim milk daily. Another varies the meat-diet with a sort of hoecake made of corn meal and sour milk. The meat used is beef or mutton in the form of butchers' scraps, unsalable parts, and the like or, most commonly, horse-meat procured especially for the purpose.

In the producing season, November to March, feed must be restricted to just the right quantity and carefully chosen. In the summer less caution is required. Two eggs should be given daily to a nursing mother for a month after the pups are born; and fresh milk three times a day. When located on the seacoast near fishing settlements fox-raisers supply fish, lobsters, and other sea-foods to their foxes at 
little or no cost, and find them satisfactory. Take care that the stronger, quicker foxes do not rob and starve their fellows.

Reproduction, and treatment of young. Foxes breed only once a year, beginning when a little less than a year old, but the first litter will be small. The mating or rutting season includes the months of February and March,

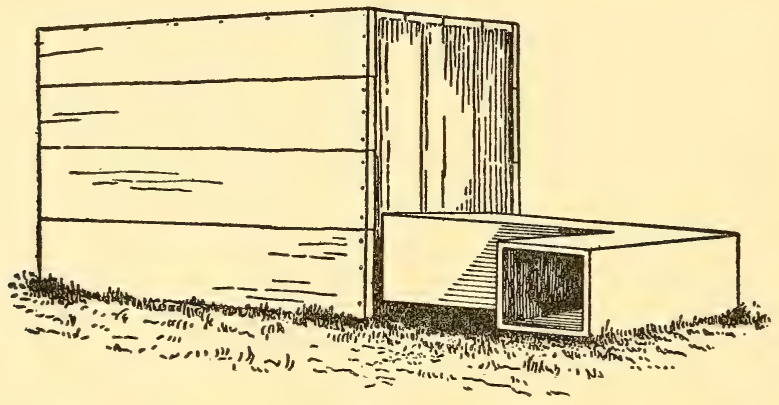

ONE FORM OF BREEDING KENNEL.

A barrel, with a similar elbowed entrance might easily take the place of this box.

and the young are born in April and May. The number of young in a litter varies from two to eight, the average number born to adult parents being five.

In the wild state foxes are monogamous. The male has only one consort, at least only one in a season. In confinement, however, one 
male sometimes has been mated successfully with two or even three females. In certain cases this may be desirable, and at an advanced stage of the business may offer no difficulties, but at first it is advisable to handle the animals in pairs. It is possible, also, as proved in a number of instances, to allow male and female to remain together throughout the year without bad results, but it is much better to keep them separate, except during the mating season. They may be paired in December or January and separated in March or April. The females should be kept in the small enclosures continuously and the young removed when weaned.

The separation of the sexes is not, as many suppose, to prevent the male from viciously killing the young; for, unless suffering from hunger, he usually is a model parent. But the presence of the male often results in injury to the female during pregnancy, resulting in abortion; or it excites her unduly after the young are born, leading to rougher treatment than they are able to stand.

Some foxes are much better breeders than 
others; some can never be induced to mate, and others mate, but do not produce young. They are constantly in a state of fear, and this fear is probably the chief cause of the failure to breed regularly. It may cause the female to refuse the attentions of the male, or, having received them, she may prove infertile, or she may become excited so as to injure herself and give birth prematurely. But, worst of all, even after producing a litter of healthy young, she may be so solicitous for their safety that in her effort to get them out of imaginary harm's way she maltreats or kills them.

When born the young are small and weak, but if all is well they grow rapidly, and when about six weeks old begin to come out to play and to lap a little milk or to take an occasional bit of solid food. If allowed to do so, they will continue to nurse for nearly six months.

Importance of good care. Keeping the foxes in a secluded place free from visitors is not sufficient alone to overcome these difficulties. Although strangers should be kept away, a regular attendant should visit the animals daily and use every effort to gain their confi- 


\section{FOXES AND FOX-FARMING}

dence. This is not easy, and a great deal depends upon the personality of the man in charge. One not thoroughly interested or not naturally fond of animals, and therefore slow to understand their ways, is not likely to succeed. Careful observation and a faculty of intuition enables a good keeper to anticipate the moods of the animals, and to interpret their actions at critical times, so as to act quickly and without violence. He knows just when the foxes are getting too much food, just when the sexes should be brought together or separated, when the female becomes pregnant, when the young should be born, when they need special attention, and when they may safely be left to the exclusive care of the mother. He is not over-inquisitive as to the number of young that are born, and seldom needs to disturb the anxious parent, relying on her actions to show whether the little ones are thriving.

\section{BREEDING FOR IMPROVED STOCK.}

Hope for increased profits in fox-raising lies almost entirely in improving the stock, and successively getting better and blacker coats, by 
selective breeding. The darker the animal the more valuable its pelt. Hence the object of every breeder should be to produce pure black foxes, or as nearly pure black as possible. To do this he must retain his darkest and most valuable animals for breeding, selling only the poorer ones. The temptation to sell animals of high value is often very great, but in the long run such animals are likely to be more profitable if kept for breeding. The possibilities of modification and improvement by selection are fully as great with wild animals as with domestic, and already have been demonstrated in the case of foxes. Some of the highest-priced fox-skins ever put on the market have been from animals reared in confinement and improved by selective breeding.

Breeding for disposition is perhaps fully as important as breeding for color. So far this has not been attempted to any extent, but in Mr. Osgood's opinion it may be of great importance in overcoming some of the principal difficulties now encountered. By selecting those animals which show the least aversion to man, due regard being paid to other qualities, 
such as prolificness, a strain may be obtained which will breed with the certainty of our domestic animals. This in time should produce a thoroughly domesticated race of foxes, a result of inestimable value, amply justifying the utmost efforts. Although it may not be fully accomplished by those who begin it, every breeder should keep its importance in mind, for every slight improvement will be to his advantage, and in the end the unqualified success of the business will be assured.

Slight improvement of individual male animals not intended for breeding may be obtained by castration. This has been tried with red foxes, and found to yield an animal of somewhat increased size. In buying a young breeding-pair of silver foxes great care is necessary. Try to see the parents of the proposed purchase. October is the best month for buying, and examination should be made in bright sunshine. An experienced breeder advises the use of a magnifying-glass in examining the fur to see if it is thick and glossy with a long dark under-fur and no trace of red, especially inside the ears. 
Preparation of skins. The preparation of skins requires some care, but no special implements or preservatives. The opening and only cut is made with a sharp-pointed knife, beginning on the bottom of one hind foot and extending up to the hind side of the leg to the vent and thence down the other leg to the foot. The entire body is removed through this opening; using the knife to separate the skin when necessary, and proceeding down over the head to the lips, where the final cuts are made. Thus the skin is turned completely inside out. The tail bone must be carefully withdrawn, preferably by the use as a vise of two firmly-held sticks (or a split stick), through which the bone is passed. To facilitate this it may sometimes be necessary to slit the tail on the under-side. The skin is then carefully fleshed-that is, all the fats and bits of flesh adhering to it are removed. To dry the skin it is slightly stretched on a long, narrow, somewhat tapering board with a blunt, rounded end. After slipping over the board (hair side in) it should be hung in a cool, dry place, and allowed to dry gradually. Ordinarily no preservative is necessary, 


\section{FOXES AND FOX-FARMING 231}

and the drying should not be hastened by exposure to the sun or artificial heat.

Expectation of profit. Every silver-fox raised is likely to yield a pelt having a market value of over $\$ 100$. Even pale skins bring this figure, and darker ones much more. Pure black skins command prices ranging from $\$ 500$ to $\$ 2,000$. It is, therefore, evident that a moderate income may be derived by raising comparatively few foxes. In the present stage of the business the sale of foxes for breeding-stock is very profitable, as the live animals in good condition often bring fully twice as much as their cured skins. In fact, good, live, silver foxes seldom can be obtained for less than $\$ 500$ per pair, and much higher prices have been paid.

The high prices paid for silver-fox skins are due to the rarity of the animals, and the extensive production of such skins would necessarily tend to a reduction in price. Increasing population and wealth, however, insure a large future demand for fine furs, and no great decrease in prices is likely to occur until production reaches large proportions. 


\section{CHAPTER XIV}

\section{GRAY WOLVES AND COYOTES}

THe time has gone by when the farmer in the eastern half of the United States has to guard his stock and perhaps his family against wolves as in the days of his forefathers. In the northern parts of Canada, however, in the forested parts of northern Michigan, Wisconsin, and: Minnesota, and in scattered localities throughout the whole Northwest, and thence northward to the Arctic regions, the great gray or timber wolf is still a menace to the ranchman if not to the cultivator of fields. It also causes the destruction of great numbers of game-especially deer,_-which can ill be spared; and now and then attacks travelers or their horses when picketed out at night.

Consequently ranchmen are everywhere making determined coöperative efforts, aided by the government, to kill them off, by breaking up their dens and trapping and poisoning the 


\section{GRAY WOLVES AND COYOTES 233}

old ones. The most effectual method is by searching out and destroying the dens and pups, of which six to ten are usually born in a litter to a pair of gray wolves. These are produced early in spring in some rocky niche or cave or sheltered hollow in the open country, and in a hollow log or stump when the region is forested. Both parents continue in company, caring for the young, until the latter are well-grown.

Character of the coyote. The smaller-reddish prairie-wolves or coyotes (coy-yó-teh) are far more widespread, numerous and annoying, though rarely dangerous; and if farming operations, with their attending domestic animals and poultry, are to be carried on in the plains country or mountain valleys of the West; and if sheep-farming is ever to be made productive there, these keen and pertinacious little wolves must be subdued. At the same time it must not be forgotten that they perform a most excellent service by killing a vast number of noxious mice, gophers, prairie-dogs, rabbits and other pests. If it were possible, then, to keep the coyote as a harmless ranger of the plains, - a sort of Cossack that freed the fron- 
tiers of marauders while doing no damage to human arts and interests-it would be a most advantageous arrangement; and it is toward this solution of the problem that efforts should be concentrated. The following general account of the animal and its habits is by David E. Lantz:

"While in general denizens of the higher open plains, coyotes are found also on the low tropical coasts of Mexico and Texas and in the higher mountain ranges of the interior. In the northern and northeastern parts of their range they inhabit partially wooded country, and even on the plains they are partial to broken and hilly sections.

"Coyotes breed once a year. The mating season is late in January or early in February. The period of gestation is about sixty-three days. The young are produced in dens and number from four to eight or even more. The dens are usually enlarged from those made by badgers or smaller animals, and are often among rocks or in washed-out places along banks of streams. Probably at times they are made entirely by the coyotes. They are rarely far below the surface, but sometimes of considerable extent, and with two or more openings. Little attempt is made to provide nests for the young. In the Central West these are born early in April, and usually may be heard in the dens during May. In June they come out to play around the mouths of the burrows, which 


\section{GRAY WOLVES AND COYOTES 235}

are finally deserted during July. By August 1 the young are left by the parents to shift for themselves.

"In the earlier descriptions the prairie wolves were usually said to hunt in packs. Lewis and Clark, Say, Richardson, and others so reported, but the Prince of Wied met them only singly. It is probable that they hunt in numbers only when the quarry is large, as in the case of deer and antelope, and as many as three have been known to pursue a single jack-rabbit.

"Coyotes feed chiefly upon animal matter, but when such food is scarce they freely eat peaches, apricots, grapes, and other fruits, and even melons, usually destroying more than they eat. In certain areas they feed largely on juniper berries, manzanita berries, and the fruit of the prickly pear. . . . Horned toads and other lizards are eaten, and, on the low, tropical coast of eastern Mexico and Texas, coyotes have been seen searching the beach for crabs, fish and turtle-eggs.

"Beneficial food-habits. Coyotes destroy many injurious species of mammals, and in this way are of positive benefit to farming interests. The various species of jack-rabbit are often included in their diet, and the smaller rabbits are habitually eaten. The constant warfare of the coyote upon these rodents has much influence in keeping down their numbers, and the growing abundance of rabbits in some sections of the West has been attributed to the destruction of coyotes as the result of high bounties offered for them.

"Prairie-dogs also are a staple coyote food. The 
coyote usually captures them by hiding behind clumps of weeds or bunches of grass at some distance from the burrows, and when, in feeding, the unsuspecting rodent approaches near enough a few leaps enable the coyote to capture it. It is probably the fear of the coyote that causes the prairie-dogs to crop off all the tall, growing grass and weeds near their burrows.

"In addition to rabbits and prairie-dogs the food of the coyote includes rice-rats, kangaroo-rats, woodrats, ground-squirrels, woodchucks, pocket-gophers, chipmunks, and pocket-mice. All of these are harmful to agriculture, and the coyote in preying upon them performs a valuable service to man. This service is not spasmodic, but lasts throughout the year and throughout the life of the coyote, and has an important influence in helping maintain the 'balance of nature.'

"The coyote is useful also as a scavenger. In the prairie country, especially in winter, it comes into towns at night searching for garbage. Here it finds remnants of meat from the table, offal, and similar prizes. When hungry it rejects no animal food, not even carrion. The slaughter-houses near the towns are favorite feeding places, and the animals are often shot there. On the ranges they soon consume dead horses and cattle, leaving the bones clean.

"Injurious food-habits. Considerable game is destroyed by coyotes, including quail, grouse, and wild ducks, and their eggs. . . . hens, ducks, geese, and turkeys. Its usual method of capturing 
them in daytime is to lurk behind weeds or bushes until the fowls are within reach. Turkeys, which range far afield in search of grasshoppers and other insects, are frequent victims. At night the coyote captures poultry from the roost unless eare is taken to guard against its entrance. A correspondent of the Biological Survey wrote from Rexburg, Idaho, that one neighbor lost 60 chickens and another 30 in one night by coyotes. A correspondent in Mayer, Ariz., wrote that he had lost about a hundred chickens by coyotes, but that, although they destroyed poultry, he believed them to be beneficial, as they kept down the rabbit pest.

"In approaching ranch buildings, either by day or by night, the coyote comes from the leeward side and with great caution; but once satisfied that no danger lurks in the shadows, it becomes very bold."

The coyote as a pest. Few of the mammals of the farm are exempt from the raids of this enterprising little wolf, whose record of misdeeds includes the capture and death of young colts, calves, pigs, lambs and goats. The coyote watches until the little ones are left unguarded a moment by their mothers, then rushes in. Under exceptional circumstances old animals may be pulled down. It is especially, however, as an enemy of sheep that this hardy wolf becomes important in its relation to human 
industry. In many parts of the West the raising of sheep has been greatly deterred on this account; and woeful stories of destruction are on record. It was this state of affairs that led the Biological Survey a few years ago to make special studies of the coyote situation.

"It is evident that the wealth of any State can be materially increased if it is possible everywhere to keep small flocks of sheep. Flocks increase rapidly under favorable conditions and good management, and the cost of keeping is small when herders can be dispensed with. The double product, wool and mutton, usually places the profit of handling sheep above that of cattle or horses. The gains also come oftener, since sheep mature in a year, while cattle and horses require three.

"In the region about Seguin, Tex., according to Vernon Bailey, chief field-naturalist of the Biological Survey, no sheep are kept, because of the abundance of coyotes. The farmers admit the advantage of introducing sheep, but the fear of coyotes deters them from the experiment. Similar conditions prevail over large areas in many parts of the West. The number of sheep in the United States has been decreasing during the past two years [1904-5], while the price of wool has been excellent and the demand for mutton steadily increasing. Montana, with an area of 146,000 square miles, leads the States in the number of sheep kept, which is 5,638,967. Yet Eng- 


\section{GRAY WOLVES AND COYOTES 239}

land, with an area of only 50,867 square miles, has about five times as many as Montana. In Montana sheep are herded in immense flocks; in England every landowner and farmer keeps a small flock.

"The advantage of sheep upon the farm as weeddestroyers is not usually appreciated in America. The Iowa Agricultural Experiment Station reports that out of 600 species of grasses and weeds, cattle are known to eat only 50 , horses 82 , while sheep eat 550 . With abundance of pasturage, favorable climate, good prices for wool and mutton, and increased fertility and productiveness of the soil upon which sheep are grazed, there should be a decided advance in the sheep industry.

"The chief discouragement seems to lie in the depredations of worthless dogs and coyotes. The evil of worthless dogs can be best remedied by a resort to taxation. Dogs should be regarded as property and taxed sufficiently to put all of the dangerous and worthless curs out of existence."

The methods which have and may be used to lessen this pest by traps and poison are discussed in the final chapter. Here it may be said that none of them are as satisfactory as fencing, in spite of the stimulation of bounties by States and counties, and of the encouragement of hunting coyotes as a sport-and good sport it is when one rides to Russian wolfhounds or greyhounds. 
Fencing against other wild animals. Fencing as a means of protection against wild animals has for several years been in use in the Australian colonies and in South Africa. In Australia wire nettings are used successfully to keep rabbits, dingoes, and some species of kangaroos out of pastures and crops. In Cape Colony jackals are a great hindrance to sheepand ostrich-farming, and have been successfully checked only by wire-fencing they could not get over, nor under nor through. The expense of such fencing in our own plains country would probably be $\$ 250$ a mile; but it would pay for itself, according to the South African experience, in the increased number of lambs reared, fleece secured, health of the stock, improved pasturage and less cost of herding.

To those interested these arguments do not need expanding nor expounding; nor is it needful to explain and discuss the recommendations for various designs of fence. The following summary of recommendations made by Special Agent Lantz, of the Biological Survey, in 1905, are good for to-day, and have stood the test of experience: 
"Summary of Conclusions.-(1) Prairie coyotes will not willingly jump over a fence above 30 inches in height.

"(2) They will readily climb over fences built of horizontal rails or crossbars, especially in order to escape from captivity.

"(3) Barbed wires do not deter them from crawling through a fence to escape.

"(4) Woven-wire fences should have meshes, when rectangular, less than 6 by 6 inches to keep out coyotes. For such fences triangular meshes are much better than square ones.

"(5) In fencing against coyotes with woven fences care must be used to see that there are no openings at the ground through which the animals can force themselves, since they are more likely to crawl under a fence than to jump over it.

"(6) It seems reasonably certain that a fence constructed of woven wire with a triangular mesh not over 6 inches across and having a height of 28 to 42 inches, supplemented by two or three tightly stretched barbed wires, would prove to be coyote-proof. It is difficult to make exact estimates of the cost. Woven fences differ in weight, price, and durability, and freight charges on materials depend on the distance from distributing points. The cost of posts and labor varies much. An estimate based on so many variable factors is of little value, but an average of $\$ 200$ per mile would probably allow the use of the best materials." 


\section{CHAPTER XV \\ THE FUR-BEARERS AND THEIR CULTURE}

THere now present themselves a company of small carnivores of unusual interest in every aspect-the martens, ermines, wolverines, badgers, skunks, etc.,-all of the weasel family Mustelida. "They constitute," as I have written elsewhere, "'an army of sharp-toothed, keen-witted, bloodthirsty devourers of the small life of the world, doing in the North the police work which in the Oriental tropics is committed to the civet-cats and mungooses. These are the animals whose coats, acquired to keep themselves warm amid arctic frosts, make our most beautiful furs, as sable, marten, mink, ermine, and the rest. The sable is Siberian, the marten is North-European, and its American brother is the pine-marten, or 'sable' of the Canadian forests. The three are scarcely distinguishable, each averaging about eighteen inches in length, plus seven or eight inches of tail, 
and are brown, somewhat lighter below (throat and breast-spot orange in the Canadian sable), and variable according to age, sex, and season. The winter fur is thick, soft, an inch and a half deep, of richest hue, and has scattered through it coarse black hairs which the furrier pulls out; the tail is somewhat bushy. . . ."

Canadian fur-bearers. For two hundred and fifty years the Canadian marten has supplied, as had the sable for perhaps as many centuries, the most valuable furs sent to market, excepting a few rarities like seaotter.

North America also contains the giant of the tribe in Pennant's marten, named by the early French Canadians pekan, and by modern trappers "'fisher," "black cat," or "black fox,"-it being none of the three! It is remarkable for its great size-24 inches, plus 13 inches of tail -and for its dog-like head. A third still larger relative is the wolverine or "carcajou," an uncommonly large, clumsy, shaggy marten, of great strength, and displaying extreme perseverance and sagacity in procuring food where the supply is limited and precarious. 


\section{ANIMAL COMPETITORS}

All these, in early times common enough throughout all our northern forests, have been destroyed, or have retreated before civilization until now few are seen south of the wilds of northern Canada, where they still yield their furs to the Indian and the wandering trapper. This brings us to the more familiar weasels, minks and ferrets.

"Slender, lithe, perfectly toothed, sharp-clawed, secretively colored, and endowed with strength, speed, cleverness, and indomitable courage, the weasels are the scourge and terror of all the small ground-keeping animals, and do more than any other class of agents to restrain mice, gophers, and similar nuisances. Some or all can climb, but their preference for the ground distinguishes them from the martens, as also do the comparatively short tail, close fur, three instead of four premolar teeth, and the presence of anal glands whence they may discharge a fetid odor. This musky, nauseous secretion is most copious and evident in the large European polecat, but most distressing to human nostrils in an old mink; and ordinarily it is not very noticeable in a weasel. Its emission is under control, and becomes perceivable mainly when the animal is excited or alarmed. Its service seems to be that of attracting the sexes; and trappers save it to put upon their bait as an additional allurement." 


\section{CULTURE OF FUR-BEARERS 245}

The ermine and his family. Naturalists distinguish over 20 species and subspecies of weasel in North America. Most of them, however, belong to the West and far North, and they differ little in general character; such peculiarities as belong to each Dr. C. Hart Merriam, their monographer, connects with their food. Thus he finds that the group represented by our common eastern species (Putorius cicognani) flourishes only in the country where the meadow-mice abound; the large western weasel ( $P$. longicauda), does not range much outside of the region inhabited by the pocket-gophers; the black-footed one ( $P$. nigripes) frequents only the prairie-dog country southward; and "in the far North, where the frozen tundras are inhabited by lemmings as well as voles, two weasels are present: the tiny, narrow-skulled 'rixosus,' which feeds mainly on mice, and the large, broad-skulled 'arcticus' (analogue of the true ermine) on lemmings and rabbits.', With these fine points of classification we need not here concern ourselves. A weasel, in the Old World or in the 


\section{ANIMAL COMPETITORS}

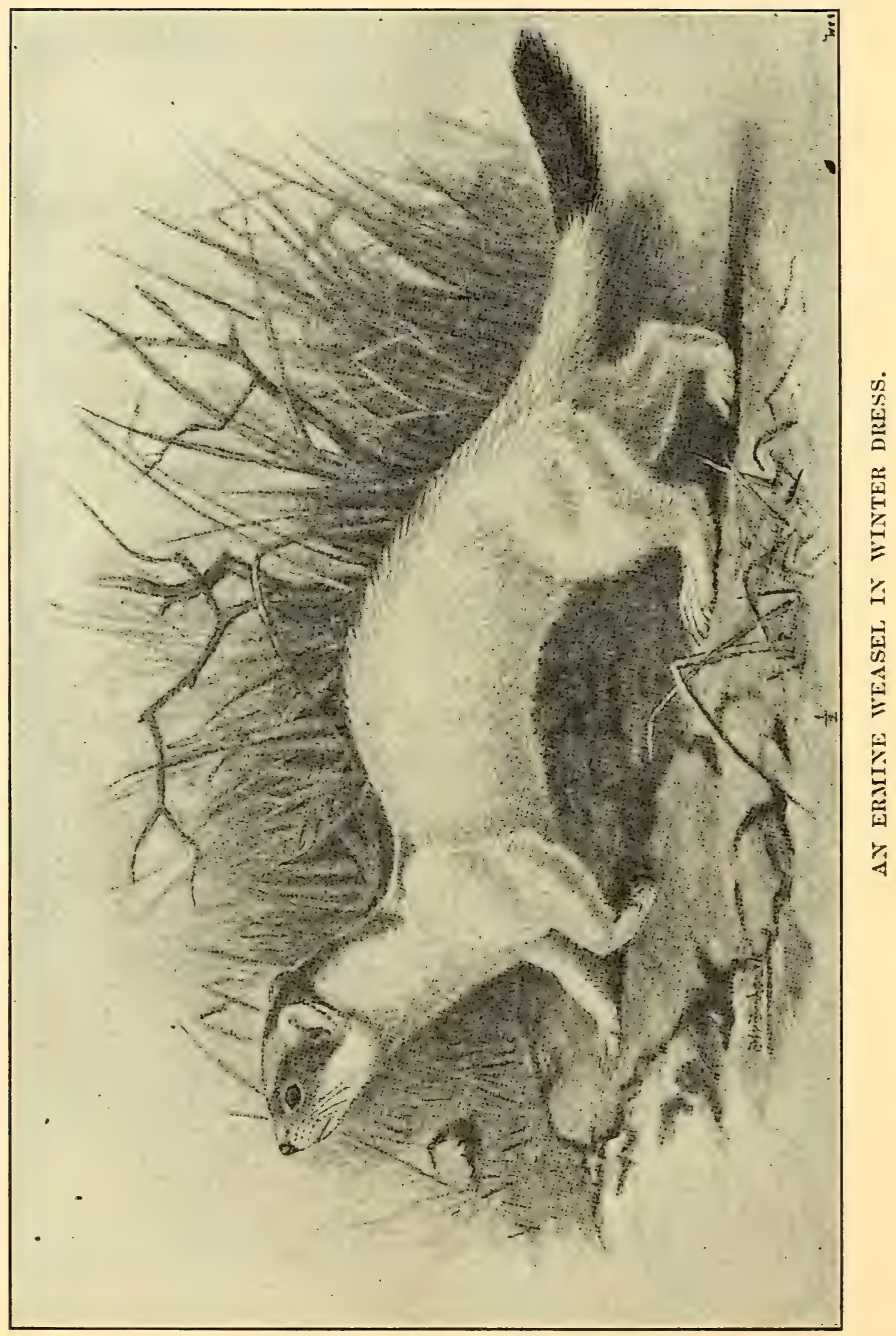


New, in Labrador, or Florida, or Mexico, on the Yukon as on the Hudson, is substantially the same,-a keen, agile, relentless, indomitable hunter, within his powers a being of the highest type of effectiveness.

"The weasel's head is small and trim, An' he is little an' long an' slim, An' quick of motion an' nimble of limb.

An' ef you'll be advised by me,

Keep wide awake when you're catchin' him."

The weasel turns white in winter in all cold, snowy latitudes-that is, when the brown summer-coat is shed in the fall it is replaced by a white one, which in turn is lost in the spring and replaced by the soft brown again. The tip of the tail, however, always remains black. In this white winter dress with the blacktipped tail every weasel is an "ermine"; and it is only in this coat that his fur becomes valuable in the market. It comes to market from Alaska, northern Canada and sub-arctic Russia, and is used mainly for trimmings of garments. In old times it was reserved exclusively for the wearing of royalty, and of certain officers of high rank. It was especially 
prominent in England in the regalia of judges; whence our figurative expression "the ermine", as a symbol of the judicial office.

Large, purely white ermine skins are still valuable in the fur-market, so that the animal is well worth the attention of trappers; but it is chiefly in its other relations that it now interests us.

Weasels and chickens. Weasels of one sort or another are more or less common in all parts of the country, even to the suburbs of the cities; and they are so swift, secretive, alert and wise that they remain everywhere numerous in spite of the constant efforts of the average countryman to kill them off.

This enmity is due mainly to the animal's delight in killing chickens, at which it is exceedingly expert and bold, often invading a barn-yard in full daylight; and when one-or more usually a pair-has acquired the habit of chicken-killing it is likely to murder the whole flock in a short time if not prevented. This bloodthirst is only a natural outcome of its habit of preying on wild birds, especially those which keep to the ground; and in places 
where quail or game is preserved the animal often does great harm.

It does not appear, however, that every weasel kills chickens, nor that the same weasel devotes its whole energies to this end, as a man-eating tiger will do when once it learns how easy it is to secure human prey. It seems, rather, that an occasional weasel now and then seizes a pullet or duck. The worst of it is, however, that when it has done so its ferocity is likely to be so fired by the taste or smell of blood that it goes on massacring the fowls after the manner of a wolf or a puma in a sheep-fold, as though in a rage of blood intoxication.

The weasel as a mouser. There is another side to the account, however, and that is the ceaseless and extensive beneficial work of these ferocious little creatures in pursuit of the rodents which year by year destroy more grain and young trees than all the poultry loss of a year amounts to a hundred times over. In the West they are the determined and indefatigable enemies of ground-squirrels, gophers and all sorts of mice, which they follow to the 
uttermost ends of their burrows if necessary. Mr. Osgood says of the small Arizona weasels: "They are the most effective enemy of pocketgophers. . . . In a narrow valley where an old weasel had her young I found it impossible to secure a single pocket-gopher. A single weasel will effectually keep down the gophers and meadow-mice on a field or small ranch. Except in very rare cases they should be protected with the greatest care." The black-footed "ferret", (a true weasel) is rarely found away from prairie-dog towns, where it plays the bandit unceasingly. The writings of naturalists abound in evidence of the same sort. A notable instance may be found in the great work on American mammals, The Quadrupeds of North America, published half a century ago by Audubon and Bachman, a few paragraphs from which may well be quoted:

"Whenever an ermine has taken up its residence the mice in its vicinity for half a mile around have been found rapidly to diminish in number. Their active little enemy is able to force its thin vermiform body into the burrows, it follows them to the end of their galleries, and destroys whole families. We have on several occasions, after a light snow, followed 
the trail of this weasel through fields and meadows, and witnessed the immense destruction which it occasioned in a single night. It enters every hole under stumps, logs, stone heaps and fences, and evidences of its bloody deeds are seen in the mutilated remains of the mice scattered on the snow. The little chipping or ground squirrel, Tamias Lysteri, takes up its residence in the vicinity of the grain-fields and is known to carry off in its cheek-pouches vast quantities of wheat and buckwheat, to serve as winter stores. The ermine instinctively discovers these snug retreats, and in the space of a few minutes destroys a whole family of these beautiful little Tamice; without even resting awhile until it has consumed its now abundant food, its appetite craving for more blood, as if impelled by an irresistible destiny, it proceeds in search of other objects on which it may glut its insatiable vampire-like thirst. The Norway rat and the common house mouse take possession of our barns, wheat stacks, and granaries, and destroy vast quantities of grain. In some instances the farmer is reluctantly compelled to pay even more than a tithe in contributions towards the support of these pests. Let, however, an ermine find its way into these barns and granaries, and there take up its winter residence, and the havoc which is made among the rats and mice will soon be observable. The ermine pursues them to their farthest retreats, and in a few weeks the premises are entirely free from their depredations. We once placed a half-domesticated ermine in an outhouse infested with rats, shutting up the holes on the 
outside to prevent their escape. The little animal soon commenced his work of destruction. The squeaking of the rats was heard throughout the day. In the evening, it came out licking its mouth, and seemed like a hound after a long chase, much fatigued. A board of the floor was raised to enable us to ascertain the result of our experiment, and an immense number of rats were observed, which, although they had been killed in different parts of the building, had been dragged together, forming a compact heap.

"The ermine is then of immense benefit to the farmer. We are of the opinion that it has been overhated and too indiscriminately persecuted.',

Again, in another place, Dr. Bachman returns to the weasel's abilities as follows:

"We have traced the footsteps of this bloodsucking" little animal on the snow, pursuing the trail of the American rabbit, and although it could not overtake its prey by superior speed, yet the timid hare soon took refuge in the hollow of a tree, or in a hole dug by the marmot or skunk. Thither it was pursued by the ermine and destroyed, the skin and other remains at the mouth of the burrow bearing evidence of the fact. We observed an ermine, after having captured a hare of the above species, first behead it and then drag the body some twenty yards over the fresh fallen snow, beneath which it was concealed, and the snow lightly pressed down over it; the little prowler displaying thereby a habit of which we became aware for the first time on that occasion. To 
avoid a dog that was in close pursuit, it mounted a tree and laid itself flat on a limb about twenty feet from the ground, from which it was finally shot. We have ascertained by successful experiments, repeated more than a hundred times, that the ermine can be employed, in the manner of the ferret of Europe, in driving our American rabbit from the burrow into which it has retreated. In one instance the ermine employed had been captured only a few days before, and its canine teeth were filed, in order to prevent its destroying the rabbit; a cord was placed around its neck to secure its return. It pursued the hare through all the windings of its burrow, and forced it to the mouth, where it could be taken in a net, or by the hand.',

Seton, in his magnificent work on Northern Mammals, relates many instances of the weasel's work in Canada, mentioning among other facts its persistent preying upon rabbits. In Lantz's Economic Study of Field-Mice is given a letter from a farmer in Waukegan, Ill., who writes :

"Two years ago a pair of weasels took up their abode in our tree-cellar, breeding there last year. They kept most of the mice killed off. In the summer we saw the old one quite often carrying mice to its young from outside the shed.' 
Weasels are extraordinarily fearless of mankind, and will soon become so regardless of him as to be positively tame. In the West miners and hunters often welcome them to their cabins and establish very friendly relations with them, recognizing that they keep the premises free from the wild mice, which otherwise would infest the houses and play havoc with supplies brought in at great expense and labor. This is only a return to a very ancient practice, for, as I have shown in my Life of Mammals, the household mouser of the Greeks was not a cat, but a weasel-the European stone-marten.

Life of the mink. The mink is a semiaquatic weasel. It inhabits the whole of the United States, excepting the arid regions, which are unfitted for its habits of life. It is a species of great economic importance, both on account of the value of its fur and on account of its injurious habits. As an enemy to. the poultry yard it ranks ahead of all other North-American mammals. Furthermore, it kills large numbers of fish, as it not only swims and dives with facility, but can remain long under water, pursuing and capturing its prey 
by following it below the surface. Oftentimes its destructiveness in this respect renders it a serious obstacle to the industry of fish-culture. Though amphibious, and commonly inhabiting the borders of ponds and streams, it makes long excursions, and is frequently found in

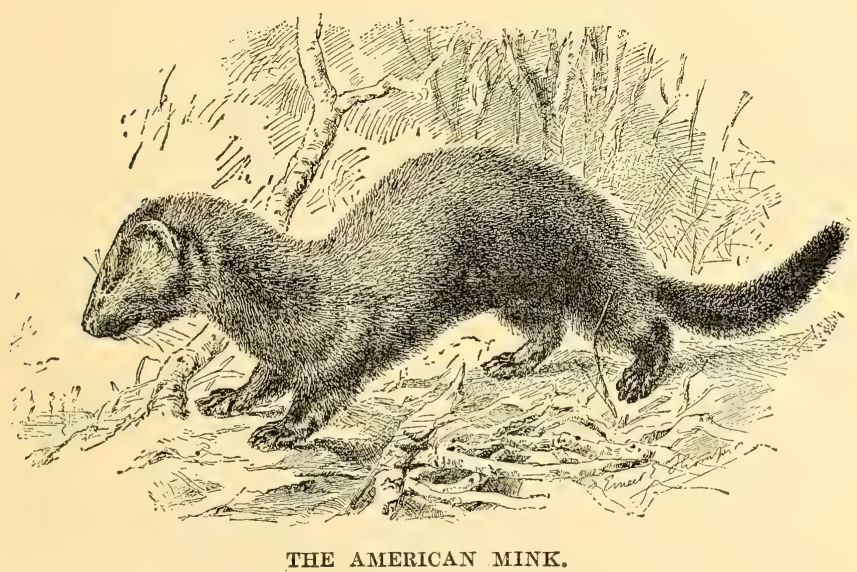

places remote from water-courses. It often takes up its abode in or near the poultry-yard or duck-pond, remaining there for weeks. Its small size and nocturnal habits help to conceal its morements, and the daily loss of a fowl is commonly attributed to the skunk, fox, weasel, or owl. The mink is remarkably strong for so 
small an animal, and has been known to drag a mallard duck more than a mile in order to get to its hole, where it was joined by its mate. Value of the mink. Such is the farmer's view of the mink, but the picture is not without a brighter side. His loss of chickens and eggs is largely due to his own slovenly way of keeping his property, or rather of trusting it to keep itself. The depredations of the mink are almost wholly made at night. A tight poultry-house will keep him out,-even a wirefence of small mesh around the yard will do so. If the chickens are allowed to roost in trees or in any old shed it is foolish to complain when they are seized by rats, weasels, minks, skunks or,- - coons.

In its natural life the mink habitually feeds upon small mammals, birds and their eggs, fish, frogs, turtles' egg's, crayfish, earthworms and the like. It is one of the busiest hunters of injurious rodents, particularly muskrats and common rats and mice. Hence it is a public benefactor in localities where muskrats damage dikes, canals, irrigating ditches, and ponds; and day by day it seeks out the runways 
of the wild mice and devours their families. If you catch sight of a prowling mink, some day, along the brookside, squeak like a mouse, and see how interested he will at once become. Indeed, a mink or a weasel which takes up its abode under a barn will soon clear out the rats.

Good mink-skins have always fetched a fair price, and this price is rising. As they are abundant, and among the most easily trapped of our wild animals they have ever been one of the sources of pocket-money to the lads of the rural parts of the country.

"The old-fashioned deadfall is the trap that should be used," Seton advises, "as it does not injure the fur and it kills the animal instantly, so that there is no unnecessary suffering. The box-trap is effectual and humane if visited regularly. It should have, at the back, a window covered with $3 / 4$-inch-mesh wire netting. It has the advantage of protecting its catch from passing marauders. The steel trap, if used, should be visited often. The less the creatures suffer the better the fur."' The pelt should be stripped and cased in the same manuer as that of the ermine or the muskrat. 
Minli cultication for profit. The raising of captive mink for the sake of the fur has been tried very often, and succeeds well where one

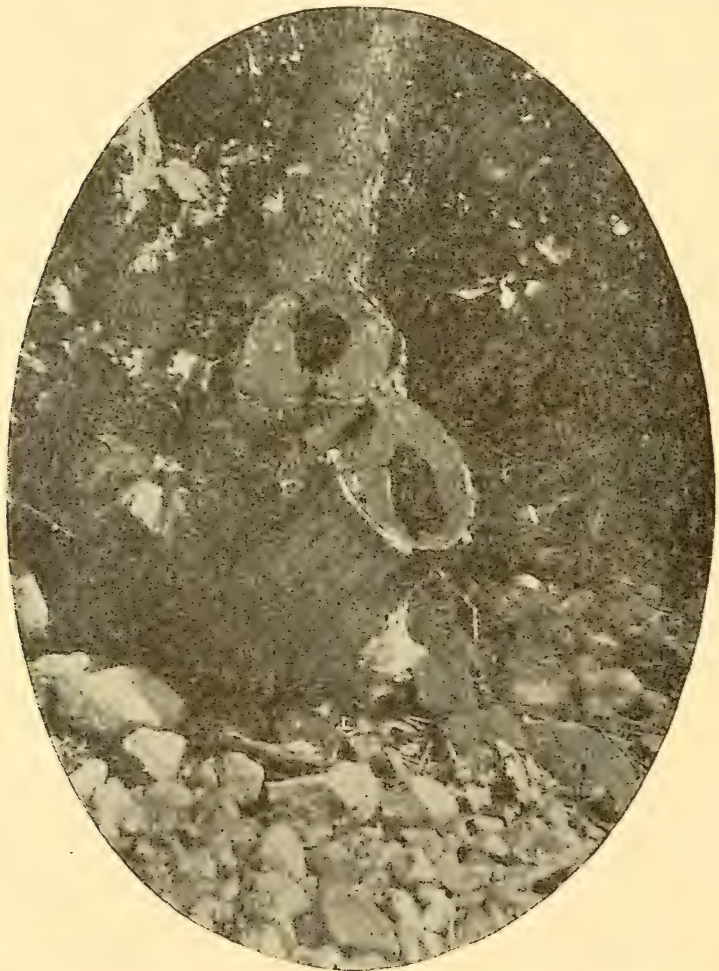

IOME OF A MINK FAMILY IX A STLMP IN NORTHERT ONTARIO.

pays proper attention to it, and the expenses can he kept low enough to ensure a profit from 
the results. Such establishments are known as "minkeries," and have been described in many publications.

It frequently happens that a pair of young minks are caught; or a full-grown male and one or more females may be bought from dealer's who advertise their wares in journals devoted to sport or to trapping. One male will suffice for five or six females. The breeding season is February, when the females all come into heat, and for three or four weeks the male should be allowed to associate with them freely. Their behavior will indicate when they no longer need his attentions. The period of gestation is 42 days, so that births will occur early in April. They number five or six, as a rule, sometimes ten, are blind, almost naked, and remain hidden in the nest for five or six weeks, when they begin to come out; but they stay with the mother, and are the object of her tender solicitude and brave defense until the end of the summer. If taken in hand when they first appear they will become as tame, gentle and playful as kittens, provided they are kept entirely away from the mother. Res- 
seque, a mink-breeder whose experience and methods are described particularly in Elliot Coues's Fur-bearing Animals, admits, however, that they become exceedingly mischievous, prying into all sorts of food receptacles, etc., and can hardly be recommended as household pets. Merriam trained some in his possession to be excellent ratters, following the rats into their holes and soon clearing all the premises of this pest.

Care of captive minks. In planning a minkery a yard say 50 feet square should be set apart and enclosed by a tight board fence 7 or 8 feet high, which should rest upon a stone or cement foundation sunk 2 feet into the ground; or else a close and strong wire netting must be deeply sunk along the bottom, for minks are good diggers. The top of the fence should have an inward overhang of tin, zinc or galvanized iron at least 2 feet wide, and still broader at the corners, or else the animals will climb out. Of course the best way would be to pave the whole interior with, and base the fence upon, concrete, but this is costly; if it is 
done the cement floor should be covered with a deep layer of earth.

At one end of this enclosure should be built of strong, close meshed wire netting, a series of cages, resting on a tight wooden floor, each about 3 feet high, 8 or 10 feet long and about 4 feet wide. These are for the use of the breeding females, one to each cage. In the front of each should be a door large enough to pass in and out a nesting-box about the size of a raisin-box, with a small hole for admittance of the animal, closed by a sliding door so that she may be shut in if desirable.

The remainder of the enclosure should be divided in the middle by a fence of close wire netting, guarded from digging and climbing like the outer fence, forming two courts or yards for exercise, etc. A small low door will afford communication between these yards. Water must be supplied in abundance-running water if possible. There should be a trough for each breeding-cage and a large swimming tank which may be accessible from both yards. The cost of such an outfit will 
vary with circumstances, but may easily be calculated.

"Mink," says Seton, "may be fed exactly as one would feed a house-cat-table-scraps varied with meat two or three times a week. Fish is very much to their liking, and may be given nearly every day if other things are used. Bread and milk, johnny-cake, etc., should be added for variety; even raw liver may be given sparingly at intervals, but cooked food, as a rule, is safer. Two light meals, morning and night, or one substantial meal, late in the day, is sufficient; and at all times an abundance of clean water. . . A fast-day once in two weeks is a good thing for fat animals."

Each old animal should have a cage to itself and be kept in it except in the breeding month (February), when a male and four, five or six females may be turned out together in one of the yards; but persistently bad-tempered ones should be taken away from the band. No bad smell will be made if general cleanliness is maintained, the yard-soil being frequently raked and overturned to remove droppings and air it. If their cages are kept clean the ani- 


\section{CULTURE OF FUR-BEARERS 263}

mals are likely to remain perfectly neat and healthy and they will breed regularly and grow fine coats. The best should always be kept for breeding, and so the stock will be steadily. improved.

The beautiful otter. The noble and beautiful otter has become so rare south of the northern wilderness, or outside of large tracts of southern swamp-lands, that it has little claim to inclusion in a book devoted to the industrial aspects of our wild quadrupeds. The food of otters is mainly fish; and in a preserved stream they may do vast damage to the angler's treasures by devouring numberless trout. They also catch and kill many muskrats. Nerriam, in his natural history of the Adirondacks, and Seton in his Northern Mammals, give extensive biographies of this most interesting and most intelligent of the mustelid race.

This brings us to the related group of furbearers which includes the badgers and skunks.

The misunderstood badger. Our badger is very similar to the European one, and formerly occurred wherever west of the Alleghanies un- 
forested country gave it the conditions it liked. Its general habits, so far as they can be observed in so shy, secretive and well-hidden a creature, are interesting, as I have shown in the chapter "A Badger and his Kin" in my Wild Neighbors. These cannot be dwelt upon here, but they show that none of our small mammals has been more misunderstood or mistakenly and wastefully persecuted. As a result the badger is now restricted in its distribution to the arid region, although scattered pairs linger here and there even in Wisconsin and Minnesota. And yet, its disappearance has not been wholly due to reckless destruction, for it seems unable to endure the forestation and cultivation of lands as they are settled. This may be due to the sedentary nature of the little beast, which is by no means a wanderer or even a traveler. Seton remarks that probably a badger never in his whole life goes a mile from the home in which he was born. The consequence is that when a family has been exterminated another is not likely to take its place. It is for this reason that a man should be careful how he wastes the life of a badger 
on his property, for not only is he putting out of business a most useful ally in his contest with nature, but is destroying one which will not easily be replaced.

Apart from that wanton, thoughtless disposition to kill any and every wild creature met with, which possesses the ruder sort of men, and most boys who have not been taught to restrain the innate savagery of the human animal, the excuses made for killing badgers are usually either that its fur is wanted or that it digs bad holes in the ground.

As to the pelt it is now of no great value, and its use is mainly to furnish hairs for artists' pencils and for the making of shavingbrushes. The hide is strong, however, and good overcoats and carriage-robes may be made of it.

Badger-holes as man-traps. The second excuse is that it digs holes in the land which may be dangerous pitfalls for horses and cattle, and which furnish runways for water that sometimes, after heavy storms, develop into bad gullies.

That this charge was originally well-founded 
I know by my own observation in the Northwest, as well as by reading. In the buffalo-country, where gophers and spermophiles dwelt in countless numbers, badger-holes were in old times extraordinarily numerous. "I do not see how they could well be more numerous anywhere," wrote Dr. Elliott Coues of the region of the Upper Missouri as he saw it in 1875.

"In some favorite stretches of sandy, sterile soil, their burrows are everywhere, together with those of kit-foxes, prairie-dogs and spermophiles, and, as already stated, these holes are a source of annoyance and even danger to the traveler. In ordinary journeying one has to keep constant lookout lest his horse suddenly goes down under him, with a foreleg deep in a badger-hole; and part of the training of the western horse is to make him look out for and avoid these pitfalls. In the buffalo country particularly, badgers live in extraordinary numbers, attracted and retained by the surety of abundant food-supply.

"The burrows of the badger are known from those of the prairie-dog and other spermophiles by their greater dimensions; besides, they differ from the former in never being built up around the entrance into the regular mound or circular buttress which usually surmounts the well-kept domicile of Cynomys. From the holes of kit-foxes and coyotes they are not distinguishable with any certainty; in fact it is probable that these animals frequently or almost habit- 
ually occupy deserted burrows of the badger, remodeled, if need be, to suit their convenience.

"But it must not be supposed that all the innumerable badger-diggings are the residences of these animals. The badger, too slow of foot to capture the nimble rodents which form its principal food, perpetually seeks them in their own retreats; and it is the work of a few minutes for this vigorous miner to so far enlarge their burrows that it can enter and reach the deepest recesses. In places where the badgers and spermophiles most abound, the continual excavation of the soil by these animals fairly undermines and honeycombs the ground."

Prehistoric plowing. The conditions above described existed mainly in regions of little use for agriculture, and as fast as civilization was extended into the badger country the animals lessened rapidly, for one reason or another, and their holes became filled up. This is illustrated by experience in Manitoba, where, as Seton informed us, "the work of the badger is now confined largely to the strips of prairie that exist along the road-allowances, where it can do but little harm."

As an offset to these troublesome habits (from man's point of view) it must be remembered that by the incessant and multitudinous 
upheaval of the ground in his digging operations, the badger has been for centuries assisting in that work of preparing the soil for man's cultivation which is the valuable heritage of the present from the small plains-animals of the past. Ever since the glaciers of the great Ice Cap left the surface of northern America an expanse of smooth rock and lifeless gravels they have been fallowing the soil of that great field which stretches from the Ohio to the Columbia, and from the Rio Grande to the Saskatchewan, and rendering it fruitful for the pasturage first of large game, next of the ranchman's herds and finally for the farmer's fat stock and for the planting of his grain and fruits.

How the badger aids the farmer. It must be remembered that the badger's food consists almost wholly of those insects and animals which prey upon crops and young orchards, and in this his services have been and are of immense and constant value. Wherever he goes he picks up insects, and in Kansas is noted to have lived very largely on the dreaded grasshoppers. Beetles and their grubs are taken, 


\section{CULTURE OF FUR-BEARERS 269}

and now and then a snake or frog, a nest of ground-building birds, or even a settler's young chickens when they wandered too far afield; but he rarely if ever raids a poultry-yard. These, however, are incidents of his carnivorous pursuits, which are mainly nocturnal. The bulk of his food is found in the small and always mischievous rodents. As Osgood says:

"Almost the whole life of the badger is spent in digging out the various rodents that constitute its food. It requires two or three fat ground squirrels a day, or a few gophers and a dozen mice, to keep a badger in good condition. . . . In case of pocketgophers the badger digs down in several places along the line of the burrow and sometimes succeeds in cornering and capturing the occupant. Mice are easily unearthed, and a nest of young mice is a special delicacy. . . . When in pursuit of a gopher, a badger may dig into and endanger ditch-banks, but in most cases the gopher, if left alone, would do far more mischief.

"Practically the only enemy of the badger is man, and it seems incomprehensible that men of intelligence should wantonly destroy on every possible occasion the most useful and least harmful of all our native mammals. So generally, however, are badgers killed that after a valley has been settled for some time they become extremely scarce, and are really in danger of local extermination. As a result one of 
the most important checks on the increase of ground squirrels, mice, and gophers is removed, and these animals occasionally surprise the farmer by taking his whole crop."

Skunks and skunk-farming. A similar plea may be made for skunks. These animals are far more widespread, equally harmless and quite as beneficial; and, like badgers, should everywhere be protected in country districts except in special cases. As for chicken-stealing, there is none of his race so little to be feared. The skunk is not as a rule a chickenthief; he is too large to creep through the small crevices that admit rats or minks, and he can't climb well. It is only needful to have a fairly well-fenced yard and tight coop to be quite safe from him.

I have many times been asked to advise as to skunk-farming, and my advice has almost always been $N o$. This was due to the fact first that with wild skunks so numerous and easily trapped, and consequently skunk-pelts so cheap as is the case at present, little or no profit could be hoped for. Yet if done intelligently and on a large scale-several hundreds of skunks sys- 
tematically looked after-the enterprise would probably turn out a fair investment.

The general directions as to housing, feeding, cleanliness and health would be substantially the same as those given for a mink-farm. Skunks, however, need much more room for

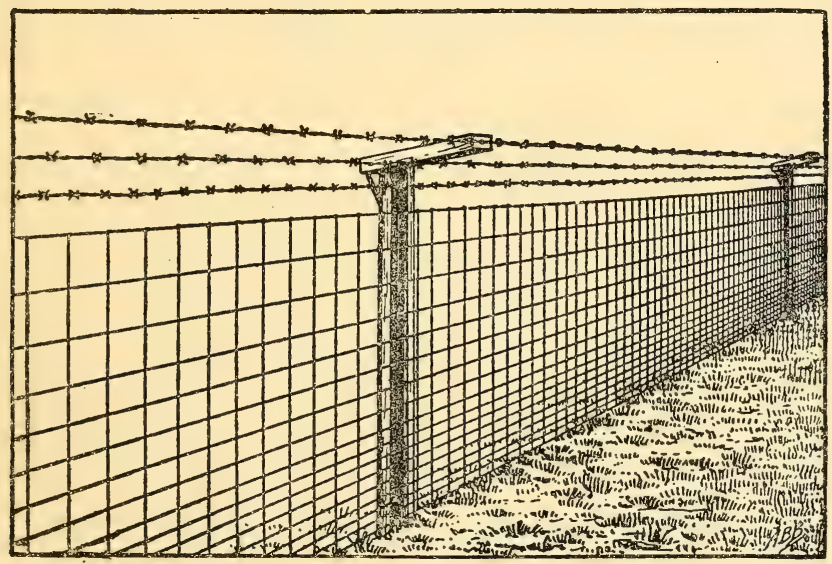

A DOG-PROOF FENCE.

wandering about, picking up insects, etc., so that several yards of an acre or so each should be provided for a large systematic skunkery, with 50 or so animals assigned to each. They are capable diggers, and the fences must be made secure at the bottom, but need be tall 
enough only to keep out dogs and other disturbers. The breeding-cages should have hollow logs or underground vaults of stone or concrete as nesting-dens; and all retiring-quarters must be roofed with a stout wire mesh to protect the occupants from great horned owls-the skunk's worst enemy-big dogs and other marauders.

If the skunks are not frightened by rough treatment there is little or no danger from the musk-gun-an instrument kept as a last resort; in fact captive skunks easily become docile and often affectionate and amusing pets. The best way to kill them, when that sad necessity arises, is by smothering with illuminating gas or some similar agent, or by drowning. The finest, blackest specimens should be selected for keeping as breeders,- - the less white on a pelt the more valuable it is. It might be possible, in a few generations, to get a strain that should be wholly black. 


\section{CHAPTER XVI}

\section{RAISING DEER FOR PROFIT}

A CHAPTER remains to be written on the wild hoofed animals of North America in their relation to the farmer and stock-breeder. This group includes the various deer, the almost extinct bison (buffalo), the antelope, the wild sheep (bighorn), the white goat, the peccary and the herds of escaped horses. Of these the most important, from our point of view, are the deer, the rearing of which, for profit, may become an industry in which the first-comers will reap a great harvest.

Native American deer. Many forms of deer are native to the United States and Canada. The moose (substantially identical with the European elk) ; the caribou in several forms identical with or very similar to the European reindeer; the wapiti, which we erroneously call "elk," and which is the American form of the red deer of Europe and its Asiatic analogues 
from the Caucasus to Kamchatka; the widely spread Virginia or white-tailed deer; the mule or jumping deer of the West; the blacktail of the Pacific coast, and many intermediate subspecies.

All these are now protected by law as the only means of saving the several species from total extinction by men who, to say the least, are utterly selfish; and there seems no good reason why some of them should not be cultivated, so as to form herds whose flesh and skins may be regularly sold as are those of cattle and sheep. This is doubly desirable as an economic movement, since it will not only add to the food-resources of the nation but may be a means of utilizing tracts of rough sterile land which otherwise will continue to lie idle.

That venison is good food needs no proof, but it is not generally understood that besides having a most attractive flavor, and lending itself well to various methods of cooking, it is in composition and nutrient quality very similar to beef, and exceeds mutton in food-value, while quite as easily digestible. Venison is in constant demand-far greater demand than 
can be supplied; and this will always be true; while the price is correspondingly high. The skins and horns of deer are also steadily salable at remunerative rates.

Capability of domestication. It has been shown by centuries of experience in parks that deer of all kinds are susceptible of cultivation, thriving and breeding readily in captivity under reasonable conditions, yet few attempts have been made to rear or domesticate them under intelligent management. Foremost among the exceptions to this negligence must be mentioned the work of the Duke of Bedford in his park at Woburn Abbey, England, where a large number of species are assembled under the most favorable arrangement for their increase.

"But raising deer for profit does not necessarily imply their complete domestication," as Mr. Lantz remarks in a Bulletin on this subject issued by the U. S. Department of Agriculture in 1908. "They may be kept in large preserves with surroundings as nearly natural as possible and their domestication entirely ignored. Thus the breeder may reap nearly all the profit 
that could be expected from a domestic herd, while the animals escape most of the dangers incident to close captivity. But the breeder who aims at the ultimate domestication of the animals, and whose herd approaches nearest to true domesticity, will in the end be most successful."

Rearing wapiti for profit. Of the various kinds of deer, native and foreign, with which one might stock a range or park, the most profitable, at any rate in the eastern or central parts of the country, would be elk (wapiti) and white-tailed deer. Breeding-stock of both these species is most easy to get, both are hardy in various climates and each has been tried by observant experimenters.

The best ground for an enterprise of this kind is precisely that of least value otherwise, - a rough tract, well watered and having some high nut-bearing timber and much brush with grassy spaces among it. Deer are both browsers and grazers-the elk eating grass much more freely than the whitetail. (Of course the two would not be herded together.) Where deep snow does not cover the ground for long 


\section{RAISING DEER FOR PROFIT 277}

periods both deer will subsist very well in winter, the whitetail on browse, and the elk by pawing away light snow and eating the grass; but even where not required by the severity of the season regular winter feeding is advised. "Hay and cornfodder are excellent winter forage; but alfalfa hay has proved to be the best dry food for both elk and deer. A little oats or corn-whole or chopped-may be fed each day. Elk are fond of corn, and feeding it affords excellent opportunities for winning their confidence and taming them. The same may be said of salt, which should be furnished liberally to all deer kept in enclosures. Running water, although not essential, is of great importance in maintaining elk in good condition." If not closely confined elk do not gnaw the bark from trees nor eat evergreen foliage; but, like goats, they do clear out the thickets.

The providing of a buck and a few does to start with is not very expensive; but a rather costly item of preparation is the fencing. Ordinarily a five-foot fence is sufficient, especially in the case of elk, which are less inclined to jump than are other deer. Old bucks, and 
even the young ones in the rutting season, are highly excitable, if not really vicious, and for these must be provided small and strong enclosures. It is, indeed, unsafe to let a male elk over four years old run at large, especially if he has once shown viciousness. The remedy for this is castration, which not only makes him docile but improves the venison; and all except the small breeding stud, frequently changed, should be so treated when young.

"We find from long experience," writes a man who has made a business of deer-farming in the Ozark Mountains of Arkansas, "that cattle, sheep and goats can be grazed in the same lots with elk, providing, however, that the lots or enclosures are not small; the larger the area the better. . . . An elk is the natural enemy of dogs and wolves. We suffered great losses to our flocks until we learned this fact; since then we have had no loss. A few elk in a thousand-acre pasture will absolutely protect the flocks therein.

The whitetail as an investment. Virginia deer are even better adapted than elk to rocky forested places, such as are so numerous in the Alleghenies. "Advocates of the Angora-goat industry state that within the United States 
there are 250,000,000 acres of land not suited to tillage or to the pasture of cattle, horses or sheep, which are well adapted to goats." Much of this land, it has been well suggested, is suited also to deer, and can be utilized for these animals with less injury to the forestcover than would result from the browsing of goats.

A herd of whitetail favorably located and properly cared for will increase in a steady and rapid ratio. The rutting season is in November, and the fawns are born in May and June. A doe will breed when 18 months old, and at first produces only a single fawn, but afterward usually two fawns. Certain diseases, especially "black tongue," are to be feared, but an annual increase of 60 or 70 per cent. may be confidently looked for. Like elk the whitetails require a certain amount of winter feed; and also should have shelter provided against the winter storms. A stack of clover or pea hay to which they may have free access in winter is recommended; and they need plenty of water -a stream or pond being especially good for them. 
In selecting herd-bucks an intelligent owner will naturally seek the best in all respects; and if this were carried out generally a greatly improved breed of deer would presently be developed.

The great hindrance in the way of instituting profitable enterprises in this much-to-be desired direction is the present condition of the laws relating to deer and venison, which have been made wholly with reference to sportsmen and pot-hunters. These laws vary locally, but in every state, probably, must be modified to admit of deer-farming and the sale of its products. Such modifications will probably take the form of licensing private deer-parks and breeding-farms, with a method of tagging the venison so that it can be easily identified. Some progress in this direction has already been made, and more will follow as the industry grows.

$A$ pest of wild horses. In some parts of the West bands of wild horses, derived from escaped stock, roam over the thinly settled plains and hills, and threaten to become a serious nuisance. The United States Forest Service re- 


\section{RAISING DEER FOR PROFIT 281}

cently stated that there are fifteen thousand of these untamed beasts upon the Toiyabe, Toquina and Monitor forest reserves in Landor County, Nevada, alone, and many more in neighboring districts. No fence is strong enough to stop these horses, and when they appear in force they have even been known to knock down and kill cows and calves. After each visitation from a herd the ranchman is likely to mourn the loss of his domestic horses, and it requires only a few days' association with their new companions for the best-broken animals to become as wild as their nomadic comrades.

The Legislature of Nevada passed a law many years ago allowing hunters to shoot wild horses and to sell their hides. The law opened the way to a new and profitable industry, and one which had the added zest of sport. Presently, however, hide-hunters began to kill also branded and shod horses, and this caused a quick repeal of the law. This left the animals free to increase, and now they have become a serious pest.

On the ranges of many of the national forests 
the supervisors have been trying for several years to devise a method to meet the difficulty in the face of the prohibitions enacted by local laws. The solution of the problem remains to be worked out.

Texan musk-hogs. The small wild pig of western Texas, known in books as collared peccary, and to Texans as javelin or muskhog, is more interesting than important. Once spread as far north as Arkansas, these pigs now abound only in the sandy, rocky districts along the lower Rio Grande, where they are extremely wary, hiding during the day in swamps, thorny thickets or among rocks, so that it is difficult to get near them without the aid of dogs and horses. Occasionally sportsmen attempt to utilize this game for "pig-sticking" after East-Indian methods, but the sport usually involves severe injury to the horses before the tough little boar succumbs. They have formidable tusks in both jaws, those of the upper jaw being turned downward instead of upward as in typical swine, and all four as keen as knives. They run, when chased in open ground, with great fleetness, but will 
squat and dodge like a rabbit, and it is at these quick turns that the horses get gashed.

At night the javelins sally forth to dig roots, mushrooms, etc., and to feed upon nuts and acorns, the latter now forming their chief fare in Texas. They also kill and eat snakes, lizards, frogs, and any other small animals they can catch. Near settlements they are, or used to be, a nuisance by entering and damaging gardens and planted fields. These animals are to be seen in most zoölogical gardens where they thrive and grow tame; but they have few qualities to recommend them in a practical way.

Bighorn and mountain goat. The bighorn is easily domesticated and would doubtless flourish in any dry and elevated part of the country, but it appears to be of no practical value except for its flesh, and the gamy quality of that, which now recommends it, would probably disappear in animals raised in a corral and fed an unvaried pasture or lowland fodder. The same may be said of the pronghorn antelope. Its flesh is a better "venison" than that of the sheep; but is difficult to adapt to cap- 
tivity, and would make more expense and trouble for its owner than the returns would be worth in the present state of the meat-market.

The beautiful Rocky Mountain white goat, like the bighorn, is chiefly interesting and of value as an object of sport. Its flesh is very poor eating, and its pelt worthless, but its thick white hair and wool have been used by the Pacific Coast Indians from time immemorial for making robes, etc., and could enough of this fine soft coat be obtained doubtless civilized skill would transform it into beautiful fabrics. Perhaps the rearing of these goats may at some future time become an industry of Alaska and the Yukon Territory, where a large fixed population will slowly but surely be accumulated.

Pronghorned antelope and bison. Anything for the preservation of this beautiful pronghorn, once so abundant in the West, must be done quickly. Late in 1910 eight head of this antelope, selected from the National herd in Yellowstone Park, were placed in the Wichita National Game Refuge in Oklahoma, through the generosity of members of the 
Boone and Crockett Club of New York, who bore the expenses of the transfer.

The pronghorn is unlike any other antelope on the face of the earth, and has so many peculiarities that naturalists class it in a family by itself. Formerly existing by thousands on our open western plains, it has now been so reduced in numbers that its absolute extinction is certain in the very near future unless protection is given to the few remaining. It does not do well east of the Mississippi river, and can not be successfully bred in captivity; but it thrives if allowed to roam practically free within large enclosures and under conditions closely approaching the natural ones. In 1908 the Biological Survey estimated that the total number of antelope in the United States had been reduced to 17,000. Of these about 10,000 were in Montana, Wyoming, and the Yellowstone National Park, and the remaining 7,000 were distributed in 12 other states. On the Wichita Game Refuge it is hoped that the antelope will find themselves in surroundings suited to their increase.

The Wichita is really a National Forest, but 
was set aside by Act of Congress as one of the two National Game Refuges because of its especial suitability as a breeding-place for the wild creatures of the plains. This does not mean that outside of these refuges the game on the National Forests is not protected, for the officers of the Forest Service are uniformly instructed to see that the game laws of the various states are observed on their forests, in so far as they can do this in justice to their other duties. Many of the Forest officers are regularly appointed Deputy State Game Wardens, and it is the policy of the Department of Agriculture to encourage their acting in this capacity when they can do so without prejudice to their work as Forest officers. In the Wichita and the Grand Canyon Game Refuges the Government has not left the matter of caring for game protection wholly to the States, but has established national reservations on which an attempt will be made to breed game.

The Wichita Refuge is further notable for the fact that it has a small herd of buffalo upon it, donated by the American Bison So- 


\section{RAISING DEER FOR PROFIT 287}

ciety and shipped from the New York Zoölogical Garden in 1908. They then numbered 15, and in two years had been increased by the addition of 10 calves; but two of the original herd had died.

The bison seems destined to remain with us only as an object of curious interest, and a reminder of the vast herds which so short a time ago pastured on our western plains. "Interesting as have been the experiments made by Mr. C. J. Jones and others, in the crossbreeding of buffaloes with domestic cattle," declares W. T. Hornaday, than whom none is more fitted to render a verdict, "it is now quite time that all such experiments should cease. It has been proven conclusively that it is impossible to introduce and maintain a tangible strain of buffalo blood into the mass of western range-cattle." 


\section{CHAPTER XVII}

\section{DIRECTIONS FOR POISONING AND TRAPPING}

ThE most effective method of warfare against the multitude of rodent pests of the granary, garden, field and orchard, and the wolf-enemies of the sheepfold, is undoubtedly by the use of poison. The employment of this agent requires knowledge and care, however, since it is equally dangerous to animals that the farmer has no desire to kill, and to himself and his family. Fortunately for us, therefore, we can now avail ourselves of the results of much experience and of carefully formulated advice prepared by experts.

Waste of effort. We are met at the outset by the startling statement from the Biological Survey that "at present fully half the expenditure in the United States for rodent poisons is wasted." As it is added that "in the West the people of a single county sometimes expend $\$ 25,000$ to $\$ 30,000$ a year for poisons for de- 
stroying rodent pests," and as insecticides and other poisons for the entire country cost many millions of dollars annually, the saving of waste in this item of agricultural expense is seen to be important.

Probably the buyer of proprietary poisons has the greatest cause for complaint. Often one or two cents' worth of material is retailed at from 25 cents to a dollar. The difference between the cost of the material and the selling price represents the manufacturer's profit and the retailer's profit. Such large returns enable proprietors to spend much money in advertising or otherwise exploiting their wares, which, if not worthless, are never so good as an intelligent man may compound for himself at a small fraction of their price. It is to enable the readers of this book to do so that the instructions which follow are here given. They are formulas which have been dictated by scientific knowledge and approved by experience; and the methods of application recommended are those which have been found to involve the least possible danger to man, to domestic stock, and to valuable wild birds and mammals. It 
should be remembered, however, that in most states laws exist relative to the putting out of poisons; and every man should inform himself as to these laws in his locality before beginning operations.

Phosphorus and arsenic. The poisons most commonly used to destroy mammal pests in America are phosphorus, arsenic, and strychnine.

Yellow phosphorus seems to be the one most in use for the destruction of rats and other rodents, but there are several serious objections to it. First, a fourth of a grain is a dangerous and sometimes fatal dose for a human being. ${ }^{1}$ Second, its slow, irritant action causes needless torture to the animals killed-something we have no right to do. Third, it is very likely to cause disastrous fires. This substance is kept and cut under water and should not be touched with the hands. Its efficiency depends upon the fineness of its division, which is accomplished by first dissolving

1 Essence of turpentine is said to be a positive antidote for phosphorus poison, and a cure for external burns by this element. 


\section{POISONING AND TRAPPING 291}

the phosphorus in carbon disulphide, after which the substance is mixed with any suitable material, as flour or meal or glucose in the rat and roach pastes (from 2 to 4 per cent. strong), or is formed into the waxy sticks offered for sale. Now its instability in contact with the oxygen of the air is so great that it is liable when dry, and has been known, to burst into flame, setting fire to everything it touched. Cases have occurred in the West where it has thus caused fires which destroyed entire fields of ripe wheat and barley, and buildings in which prepared phosphorus was stored. Some hazard attends the use even of carefully prepared phosphorus pastes.

Arsenic, in the form of Paris green or London purple is widely employed as an insecticide. It is comparatively cheap, but is by no means as deadly as phosphorus or strychnine. The smallest quantity known to have been fatal to a human being is 2.5 grains. Its action on rodents is exceedingly variable, and there is ample proof that rats after taking small doses frequently become entirely immune to its further effects. Moreover, it is likely to sour 
baits, and so prevent their being readily eaten by the creatures to be got rid of.

Virtues of strychnine. Strychnine is one of four alkaloids obtained from nux vomica, the seed of a tree known to botanists as Strychnos nux vomica. The chief supply comes from the Malabar coast, India. It consists of colorless crystals or white powder, and of several salts, chiefly the sulphate and the nitrate, in needlelike crystals. On account of its solubility the sulphate is most convenient for poisoning small animals, and is the one which should always be used. Strychnine is very bitter, and to disguise this sugar, honey, or an equivalent of its weight in saccharine, is mixed with the powdered poison; but this is not required for rabbits and field-mice, which are accustomed to bitter foods.

As a poison for noxious animals strychnine has several advantages over the others commonly in use. It kills quickly, without the long tortures of corrosive poisons. It spite of its bitterness, baits containing it are rejected less often than those containing arsenic. If strychnine is properly labeled and kept from children, it is less dangerous to have on the premises 
than most other poisons. Should strychnine be accidentally swallowed by an adult, antidotes are usually available, and by prompt action a fatal result may be prevented. ${ }^{1}$

Experiments by the Biological Survey show that strychnine, all things considered, is a cheaper poison than arsenic. Strychnia sulphate may be purchased in bulk at about 75 cents an ounce; white arsenic costs about 15 cents a pound. An ounce of strychnine will thoroughly poison 60 pounds of wheat intended for field-mice; a pound of arsenic will poison only 10 to 12 pounds of the grain for the same purpose. The cost of preparing the 60 pounds of wheat, therefore, will be about the same with either poison; but more of that containing

1 "In case of poisoning by strychnine an emetic should be promptly given - a teaspoonful of mustard in a glass of water (warm, if available). Another excellent emetic is zine sulphate (10 to 60 grains in tepid water) or apomorphine (4 drops by hypodermic injection). A stomach pump cannot be used after the first few minutes. As soon as the emetic has acted, the patient should be put slightly under the influence of chloroform or ether, and kept so for several hours. He should be kept in a darkened room and away from noise of all kinds. Further treatment may be left to the physician, who should be summoned as soon as the poisoning is discovered."-U. S. Dept. Agr., Yearbook, 1909. 
arsenic is required to kill. Actual field experiments show that an ounce of strychnine, if properly distributed, is enough to kill 4,500 prairie-dogs or large ground-squirrels, or 9,000 field-mice.

Various other poisons, both mineral and vegetable, have been used, but none is to be recommended as compared with strychnine, with the possible exception of barium carbonate as an agent for killing rats and mice about buildings. This mineral, which is cheap, has the advantage of being without taste or smell, and also that in the small doses fed to rats and mice it would be harmless to domestic animals. Its action upon rats is slow, and if exit is possible, they usually leave the premises in search of water.

Poisoning rats and house-mice. For the reasons above given phosphorus and arsenic are not recommended in poisoning rats and mice; although powdered white arsenic mixed with oatmeal and sugar, or made into a paste of 12 parts of cornmeal and one part of arsenic with whites of eggs, is often effective.

Barium carbonate may be fed in the form of 
dough composed of four parts of meal or flour and one part of the mineral; or of oatmeal with about one-eighth of its bulk of the mineral; or the barium may be spread upon toasted bread, etc. A small quantity-say a teaspoonfulshould be placed in the rat-runs, and repeated with change of bait until all the rats disappear. This is probably the best poison for use in dwelling houses.

Strychnia sulphate is too rapid in action to make it advisable for use in our houses, since the animals die and decay in their holes in the walls and foundations, but for barns, warehouses and outer premises generally it is the most effective agent. The dry crystals may be inserted in small pieces of raw meat, or toasted cheese, and these placed in the runs or burrows; or oatmeal may be moistened with a strychnine sirup, and small quantities laid in the same way.

Strychnine sirup is prepared as follows: Dissolve a half ounce of strychnia sulphate in a pint of boiling water; add a pint of thick sugar sirup and stir thoroughly. A smaller quantity of the poison may be prepared with 
a proportional quantity of water. In preparing the bait it is necessary that all the oatmeal should be moistened with the sirup. Wheat and corn are excellent alternative baits, but must be soaked in the sirup over night.

To use this poison in places occupied by poultry a good plan is to provide two boxes, one considerably larger than the other and each having two or more holes in the side, large enough to admit rats. The poisoned bait should be placed on the bottom and near the middle of the smaller box and the larger box inverted over it. Then fowls cannot get at it if they try. It must be remembered that old rats become very wise and wary, and much caution has to be used if you are to succeed.

Poisoning field-mice. The most effective poison for the short-tailed field-mice is strychnine. In the outbreak of these pests in Nevada, the best baits proved to be alfalfa and crushed wheat. An ounce of strychnia sulphate dissolved in 5 or 6 gallons of water will effectually prepare 30 pounds of chopped dry alfalfa hay; or, with $1 \frac{1}{2}$ gallons of water, will prepare 45 pounds of green alfalfa cut into short 


\section{POISONING AND TRAPPING 297}

lengths. The poisoned food is distributed near or in the mouth of burrows, a small pinch at a place, especially in cold weather, when the animals do not feed in the open. Green alfalfa bait should not be put out when the sun is hot.

In the absence of alfalfa, crushed wheat, oatmeal and corn, among the grains, and seeds of various plants, as the tomato, dandelion, sunflower and others, may be substituted. The bait should be soaked over night in a poisoned sirup, a quart of which is enough to poison half a bushel of grain. If after thorough mixing the solution is not sufficient to wet all the grain, add a little water. After standing over night, if the grain is too wet, a little dry corn-meal will take up the excess of moisture. If oatmeal is used as a bait, when the mass is wet throughout with the sirup, it may be used immediately.

Because of the danger of destroying native birds, such as quail, the poisoned bait should be placed only under shelters which will admit mice but exclude birds. Wide boards lying upon thin cross-pieces of wood are excellent for the purpose. For pine mice baits may be 
placed in the underground tunnels. For other mice pieces of drain tile may be laid along the trails, and the baits inserted into the tiles with a long knife or spoon; old tin cans with flattened ends or small openings are excellent substitutes for tiles. One trick of wolf-poisoners in Colorado, was to make their strychnine pellets chiefly of lard so that if not eaten at night they would melt and soak into the ground, out of danger, in the next day's warm sun.

Winter is the most favorable season for poisoning field-mice, and the best time to set the poison is in the evening of a mild day. At that season cut small twigs or suckers from appletrees, and either dip them in the strychnine sirup or apply the sirup to them with a brush. Scatter the poisoned twigs near the trees to be protected. This plan is excellent for either field-mice or rabbits, and it entirely obviates the danger of poisoning birds or domestic animals.

Poisoning rabbits. Winter has proved to be the best time for poisoning rabbits, especially the western jack-rabbits, since there is no green food to attract them from the prepared titbits. Pieces of apple, carrot, sweet potato, 
melon-rind and the like are favorite baits. Crystals of strychnine sulphate are inserted in them and they are left along rabbit-runs, either on the ground or elevated on short sticks. Artificial runs may be made in orchards with a drag or a one-horse scraper. Another excellent bait is oatmeal soaked in strychnine sirup. In any case the rabbits must be carefully fenced away from haystacks, or they may not eat the poisoned bait.

Poisoning prairie-dogs and ground-squirrels. A few years ago the State of Kansas carried on extensive operations against prairiedogs, destroying them almost completely over nearly 2,000,000 acres of thickly infested land. The poison was prepared at the State Agricultural College, and was sold to townships and individuals at cost, or the formula for preparing it was given to citizens who asked for it. A modification was found necessary, however, when the mixture was to be used in large quantities and this was perfected by David E. Lantz, with the following result: For 1 gallon poisoned sirup, use- 
4 ounces powdered strychnia sulphate;

4 ounces potassium cyanid;

4 ounces green coffee;

6 ounces alcohol;

4 eggs (whites only);

$1 / 2$ gallon thick sugar sirup.

Mix the coffee and whites of eggs, and let the mixture stand over night. Dissolve the cyanid of potassium in a little less than a quart of hot water, and let it cool before using. Prepare the sugar sirup previously, so that it is not hot when used. Pour the cyanid of potassium solution over the coffee-and-egg mixture, stir, and then strain into the mixing vessel through a sieve fine enough to hold the coffee, which is rejected. Add the sugar sirup and stir thoroughly. Dissolve the strychnia in a little less than a quart of boiling water. Pour the alcohol into this solution and stir. Then add the mixture of strychnine, alcohol and water to the contents of the mixing vessel and stir thoroughly. The strychnine will be precipitated by the cyanid, and when the poison is placed in a can and allowed to stand will settle at the bottom. The poison should be kept closely corked until used.

A gallon of this poisoned sirup is enough to poison two bushels of wheat. Before it is mixed with the wheat it should be thoroughly stirred or shaken, and a few pounds of cornmeal added to make the sirup adhere to the 


\section{POISONING AND TRAPPING 301}

grain. This preparation may be used immediately. Another way is to add more water and leave the wheat over night to absorb the strychnine.

Green alfalfa or alfalfa hay for poisoning prairie-dogs should be chopped into short lengths and sprinkled with strychnine water or sirup until thoroughly wet. A large metal washtub should be used as a mixing vessel. An ounce of strychnia sulphate dissolved in a half gallon of water will prepare 30 pounds of green alfalfa; or the same quantity of strychnine dissolved in 3 or 4 gallons of water will prepare 20 pounds of alfalfa hay.

For the smaller ground-squirrels, use-

1 ounce strychnia sulphate,

35 pounds clean wheat,

2 gallons water.

Dissolve the strychnine in the water in a large mixing vessel. Then pour in the wheat and allow all to simmer for an hour, the vessel being covered. Stir occasionally. The water will probably be entirely absorbed by the grain, but if not, a little corn-meal will take up the extra moisture. If preferred, the strychnine may first be dissolved in a pint of boiling water, the ingredients then mixed in a large vessel, and all 


\section{ANIMAL COMPETITORS}

left over night to absorb the poison. Distribute the poisoned wheat, a half teaspoonful at a place, at the mouth of the squirrel-burrows; do not scatter broadcast on account of the danger of killing birds. For the larger ground-squirrels reduce the quantity of wheat to 25 pounds and the water in proportion. Experiments in California in destroying the digger ground-squirrel (Clitellus beecheyi) with pieces of sugar-beets into which crystals of strychnia sulphate had been inserted with a knife gave good results; and even better success has followed the use of poisoned barley-heads.

Poisoning pocket-gophers. The pocket-gophers are readily poisoned by strychnine, especially in the late fall and early winter. Crystals may be inserted into pieces of potato, carrot, prunes or raisins, and inserted into the gopher tunnels several feet from fresh mounds. Any strong prod will answer to make the holes into which the baits may be dropped. These holes need not be closed. When the animals are in ditch-banks the tunnel should be followed by digging with a garden trowel from the freshest mound to the main runway, the bait left there, and the opening closed. Carbon bisulphide is successful with gophers only when the soil is moist and packed. 


\section{POISONING AND TRAPPING 303}

Poisoning wolves. The proper dose for a wolf is four grains of strychnia sulphate; for a coyote, two grains. Two sizes of gelatin capsules may be bought at drug-stores. Fill, cap, and carefully wipe each capsule to remove every trace of the drug from its outside. Insert this filled capsule into a piece of beefsuet the size of a walnut and close the cavity. The baits should be carried in a can or pail, and not handled except with gloved hands or with forceps. They should be dropped from horseback along trails followed regularly by wolves, or along an artificial trail made by dragging an old bone or piece of hide well saturated with some fetid scent. Or they may be placed about a carcass on which wolves feed.

Trapping rats and mice. The best of all traps for this purpose, are the cheap snapping wire traps called guillotine traps, because they catch the animal by the neck and choke the life out of it in a moment. Those made entirely of metal (see illustration on page 75) are better than those with a wooden base.

Guillotine traps, according to Lantz, should 
be baited with small pieces of German sausage (Wienerwurst) or fried bacon. A small section of an ear of corn is an excellent bait if other grain is not present. The trigger wire should be bent inward to bring the bait into proper position to permit the fall to strike the rat across the neck.

Other excellent baits for rats are oatmeal, toasted cheese, toasted bread (buttered), fish, fish offal, fresh liver, raw meat, pine nuts, apples, carrots, corn, and sunflower, squash, or pumpkin seeds. Broken fresh eggs are good bait at all seasons, and ripe tomatoes, green cucumbers, and other fresh vegetables are very tempting to the animals in winter. When seed, grain, or meal is used with a guillotine trap, it is placed on the trigger plate, or the trigger wire may be bent outward and the bait sprinkled under it.

The old-fashioned barrel-trap may often be used to advantage. For several nights rats are tolled to food placed on the tops of barrels, or a barrel, covered with stiff brown paper tied over the top so as to not be displaced or break under their weight. Then two cross- 


\section{POISONING AND TRAPPING 305}

slits are cut in the paper, through which the rats fall, while the corners spring back making a deceptive surface for the next visitor. One of many variations of this, is a barrel with a
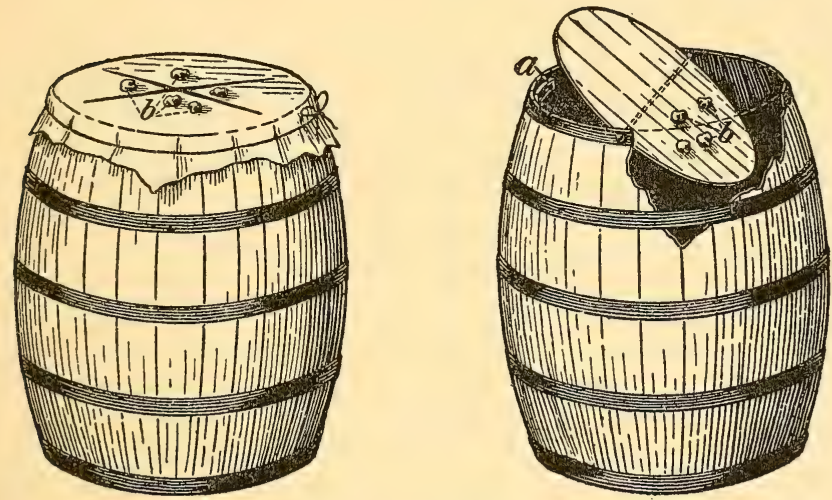

FORMS OF THE BARREL-TRAP FOR RATS.

The one on the left is covered with stiff paper, sprinkled with bait (b), and so slit that the rats fall through, while the corners of the paper fly back into place. The one on the right has a tipping cover, resting on a cleat (a) at one side.

top swinging on pivots which dumps a rat that leaps upon it, then rises level again.

When a great many rats are known to have gathered in a certain place, as under an old corn-shock (perhaps left and baited for the very purpose) a wire fence may be thrown around it, the shock overturned, and the rats killed 
by men and dogs as they come out into the enclosure.

One man reports that he has made great catches with a wire-cage trap, which he sets inside of a wooden box having a hole in one end against which the hole in the baited cagetrap is fitted. The box is then covered with trash and left. Sometimes several get in at once; especially if a single rat is left in it, whose squealing attracts others.

Large cage-traps, another advises, should be baited and left open for several nights until the rats are accustomed to enter them to obtain food. They should then be closed and freshly baited, when a large catch may be expected, especially of young rats.

Trapping is a simple way to destroy fieldmice, but it needs to be steadily and systematically continued to be of much service. It has special advantages for small areas such as lawns, gardens, and vegetable or nursery pits and packing houses, where a limited number of mice are present, and wherever, for any reason, there are objections to the laying out of poison. As voles do not readily enter cage- 


\section{POISONING AND TRAPPING 307}

traps, simple wire traps of the guillotine order, in which mice are instantly killed, are the most effective.

Traps without bait may be set across the runs of the mice, where the animals spring them by coming in contact with the trigger, or they may be baited with oat or corn meal.

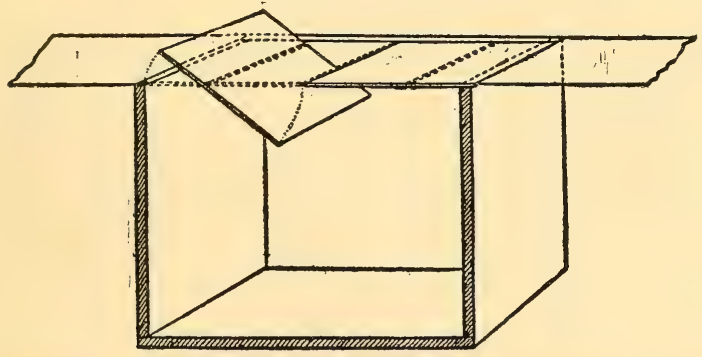

METHOD OF CONSTRUCTING A TIP-UP TRAP WITH A BOX.

For trapping pine mice an opening should be made in the underground tunnel large enough to receive the trap, which should be set across the bottom of the runway. The traps may be baited or not, but the opening should be covered.

Traps for gophers. Trapping is a successful method when followed intelligently and persistently. It is especially adapted to small 
308 ANIMAL COMPETITORS

fields, orchards, gardens, and irrigation embankments, where only a few gophers are present; but in the case of large areas that are badly infested, the method involves too much labor. An ordinary No. 0 steel trap may be employed with success, but there are on the market several special gopher-traps which are better adapted for general use.

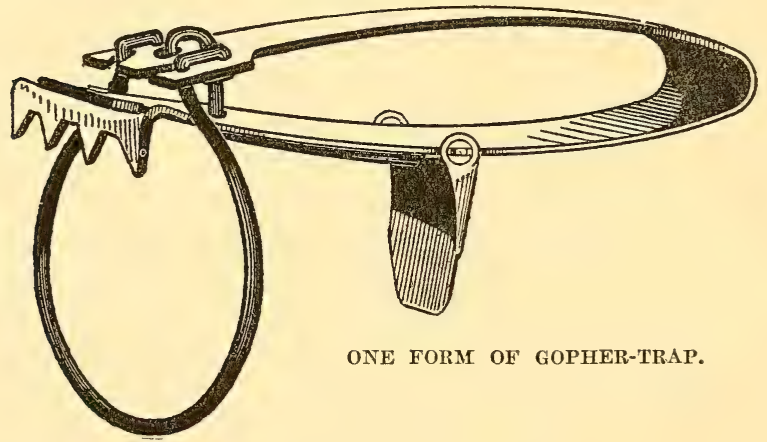

In using the ordinary steel trap, the first step is to make an opening into the main gopher tunnel. The trap should then be sunk so that the jaws are level with the bottom of the runway and lightly covered with green clover, alfalfa grass, or even loose soil, care being* taken that these do not clog under the pan, or trigger. No bait is required. The hole should 
be just large enough to receive the trap and should be covered so as almost to exclude the light. Scalding the trap frequently to remove the animal odor is important.

"A few days' experience will teach one more about setting traps for gophers than pages of directions could. He must not be discouraged by failure at first, but vary the method of setting the trap until he learns the best way for his locality. While the method is somewhat slow, persistent trapping steadily decreases the pests until the last gopher on a farm may be captured. A correspondent of the Biological Survey writes that he caught 1,332 of the animals within 2 miles of his home. A friend of the writer in Kansas trapped 350 gophers on a 40 -acre clover field in four months. A California newspaper stated that in the spring of 1901 a man near Watsonville, by using 52 traps, caught 233 in twenty-four and one-half hours. William Burniece, of Bowbells, N. Dak., trapped more than 1,500 gophers on his quarter section during a single year."

Snares and Traps for Rabbits.-Rabbits are easily trapped or snared, and few farmer-boys need instruction how to do it. An improvement upon the figure-four and similar traps is widely used in the West, and known by the name of its inventor, Fred Wellhouse, of To- 
peka, Kansas. This trap is a box of old sixinch fencing-boards, two feet or less long and 10 inches square, closed at the back by a door, but in front by a wire door only, which hangs from the top and swings inward. The trap is set and the wire door is kept open by a wire trigger-rod, held in place by two staples fastened to the top of the box. This trigger is bent downward near the rear of the trap and formed into a loop or a figure eight. As the rabbit enters the trap and crowds into the back part, it pushes upon the loop, moves the trigger wire backward, and releases the wire door. This falls and makes the rabbit a prisoner. Bait may be used, but is not necessary, since the cottontail is constantly looking for dark places to hide from enemies or cold winds. Mr. Wellhouse uses about three traps per acre in young orchards and many among the bearing trees. The materials needed are: Four boards 1 by 6,21 inches long; one piece 1 by 6 , 8 inches long for the back; a short cleat for the door stop; $281 / 2$ inches of wire to serve for the door; 22 inches of wire for the trigger; four small staples; and nails. 


\section{POISONING AND TRAPPING 311}

Trapping the wary coyote. All agree that coyotes are not easily trapped, and what is said here can be regarded as only a suggestion. These pestiferous little wolves travel in pretty well-defined paths and usually hunt against the wind. Having a keen sense of smell, they easily detect the tracks of man, and if they have had previous experience of traps or guns they are suspicious of danger.

The best No. 4 double-spring trap, with a heavy, welded wolf-chain, should be used. If the trap is to be fastened to a stationary object the chain should have a swivel at each end; if to a drag, such as a forty-pound stone (to which it must be attached with telegraph wire), one swivel next the trap is enough. Where it can be done it is a good plan to bind the trapchain to a heavy pole lying on the ground, being careful not to change its natural position. If the trap is anchored to a bush or small tree the chain must be securely fastened with snap or wire. A stout stake over which the ring will not slip, driven out of sight into the ground, is better. Every part of the trap and chain is covered, and the ground left in as 
natural and undisturbed condition as possible.

Any kind of fresh meat will do for bait-rabbits and other small rodents are often used, but larger baits seem to be more attractive. It is also of advantage after setting the trap to make a "drag" of the bait for a quarter to a half mile, at the end of a rope from the saddle horn, and finally to fasten it to a bush or stake close to the trap, or cut it in bits and scatter all around the trap, so that not all can be reached by the coyote without walking over the trap. The skill of the trapper and the situation of the trap will determine the best arrangement. The suspicion of the coyote is lessened apparently after following the bloody trail of a well-planned drag.

Before setting the traps many trappers rub their feet and hands on a skin or some strongsmelling meat or carcass to conceal the human odor. Oil of anise or rhodium is sometimes used for the same purpose. Any strong odor is likely to attract the attention of the coyote and allay suspicion. Care must be taken not to spit on the ground or kneel or throw 


\section{POISONING AND TRAPPING 313}

down any clothing in the vicinity of the trap. A good plan is to set a line of traps and leave them for a day or two, and then go the rounds with a horse and drag and bait the traps without dismounting. 



\section{INDEX}

American voles, 50 .

Bull-snakes, 188.

Antelope, 273; pronghorned, Bush-rat, 101. 284.

Arsenic, use of in destroying Canadian fur-bearers, 243.

pests, 290.

Bachman, Dr., 252.

Carcajou, 243.

Caribou, 273.

Chase, A. W., 103.

Badger, 263; badger burrows, 265; prehistoric plowing, 267 ; aids the farmer, 268.

Bailey, Vernon, 96, 99, 157, 238.

Barabaschi, Dr. P., 42.

Barium carbonate as a poison, 294.

Bats, 201; species of, 202; economic relations, 204.

Beaver, 94 et seq.

Belgian hare, 177.

Bell, Dr. Robert, 123.

Bighorn, 273, 383.

Bison, 284.

Black fox, 243.

Blanford, W. T., 7.

Bowen, George T., 82.

Breeding foxes, 227; mink, 259 ; skunks, 271.

Bristoe, W. M., 187.

Buffalo, 273.

Chipmunk, 144 et seq.; the burrow and its furniture, 145 ; familiarity, 147.

Construction, rat-proof, 28.

Cotton-rat, 68, 105; habits, 106.

Coues, Dr. Elliott, 46, 260, $266,267$.

Coyote, 232 et seq.; character of, 233 ; beneficial food habits, 235; injurious food habits, 236 ; as a pest, 237 ; fencing against, 241 ; traps for, 311 .

Cultivation of muskrats, 89 ; of the mink, 258; of skunks, 270.

Cummins, L. C., 187.

Dancing mice, 38.

Deer, 273 et seq.; native American, 273; capability 
of domestication, 275 ; rearing wapiti for profit, 276 ; rearing whitetail deer, 278. Deer-mice, 68.

Doane, Prof. R. W., 23, 152.

Enemies of rodents, 185 .

Elk, 273.

Ermine, 242; his family, 245; habits, 250 et seq.

Exterminating rodents, 191.

Fencing against wild animals, 240.

Ferrets, 32.

Fisher, 243.

Flying-squirrel, 138; charm of, 140; family life of, 141. Fox, 206 et seq.; the kit-fox, 206 ; gray fox, 208; arctic fox, 209; red fox, 210; value of fox fur, 212 ; variability of the red fox, 214; fox farming, 214; area suited for, 215; arrangement of breeding quarters, 216; form of enclosures, 217 ; easy to keep, 220 ; food and feeding rules, 221 ; reproduction and treatment of young, 224; importance of good care, 226 ; breeding for improved stock, 227; preparation of skins, 230 ; expectation of profit, 231 .

Fox-squirrel, 133; peculiarities of, 136.
Fumigation of rodents, 190. Fur-bearing animals, 242 et seq.; Canadian, 243.

Goat, Rocky Mountain white, 284.

Gopher, 112 et seq.; burrowing powers, 114; destructive to crops, 117 ; enemies to orchards and forests, 118; tap irrigating ditches, 121; as soil makers, 122; traps for, 307.

Gopher-snake, 189.

Gray squirrel, 133; peculiarities of, 136.

Ground-hog, 160.

Hardy, Manly, 130, 132.

Harvest-mice, 68.

Hornaday, W. T., 287.

Horses, wild, pest of, 280 .

House of the wood-rat, 99.

Japanese jumping mice, 38, 107.

Jones, C. T., 287.

Kangaroo rats, 107, 109.

Lantz, David E., 6, 9, 10, 15, $18,48,58,80,118,192,234$, 240, 253, 275, 299.

Marten, 242; Canadian, 243; Pennant's, 243 ; stone-marten, 254. 
Meadow-mouse, 48 et seq.; common, 51 ; general habits, 56 ; plague of, 58 ; prevention of plagues, 62 ; food of, 65 ; damage from, 66 ; prevention measures, 68; protection of orchards against, 70 .

Merriam, Dr. C. Hart, 119, $122,197,245$.

Mink, 242; life of, 254; value of, 256 ; trapping, 257 ; cultivation for profit, 258; care of, 260.

Minkeries, 259.

Mole-gopher, 113.

Moles, 194; under the lawn, 194; strength of, 196 ; methods of, 197 ; star-nosed mole, 198.

Montgomery, F. U., 9.

Moose, 273.

Mountain goat, 282.

Mouse, 37 et seq.; pantrymouse, 37 ; meadow-mouse, 48; Japanese dancing mouse, 38; prevalence of, 40 ; carry bacilli, 41 ; musical, 43; prairie mouse, 53; food habits, 55 ; wild habits, 56 ; pine mouse, 53; deer mouse, 68; pocket mouse, 68 ; harvest mouse, 68.

Musk-hog, Texan, 282.

Muskrat, 76 et seq.; mischief done by, 76 ; value of, 78 ; as a food, 80 ; recipe for cooking, 82; trapping, 84; preparation of pelt, 88 ; cultivation of, 89 ; possibilities, 90 ; suitable places and proper care, 91.

Nelson, E. W., 66.

O rehards, protection of against mice, 70 ; against rabbits, 173.

Osgood, W. H., 213, 250, 269.

Otter, 263.

Peccary, 273.

Pack-rat, 101 et seq.; thieving propensities, 102.

Pekan, 243.

Pennant's marten, 243.

Pantry-mouse, 37 et seq.

Pest of wild horses, 280.

Phosphorus, use of in destroying pests, 290.

Pine-marten, 242.

Pine-mouse, 51, 53; food habits, 55.

Piper, Stanley E., 60.

Pocket-mouse, 68.

Poisoning and trapping, directions, 288 et seq.; waste of effort, 288; phosphorus and arsenic, 290 ; virtues of strychnine, 292; poisoning rats and house mice, 294 ; poisoning field-mice, 296; poisoning rabbits, 298; poisoning prairie dogs, 299; 
poisoning pocket-gophers, 302 ; poisoning wolves, 303 . Porcupine, 161.

Prairie-dog, 153; dwellings, 156; a serious pest problem, 157; poison for, 299.

Prairie-mouse, 51, 53.

Preparation of fox skins, 230.

Rabbit, 164 et seq.; excellence of flesh, 164; breeding habits, 166 ; injurious to gardens, 168; laws protecting, 169; bounty on, 170; hunting, 171; protections against, 173 ; as pets, 177 ; hutches, 179; feeding, 181; directions for breeding, 183; traps for, 301 .

Rat, 3 et seq.; brown houserat, 3 ; black rat, 4 ; habits, 5; history, 6 ; fecundity, 8; cost, 10; destructiveness in fields, 12; destructiveness to poultry, 15; damage to buildings and stored goods, 17 ; carriers of disease, 19 ; responsible for the plague, 21 ; methods of suppression, 26 ; rat-proof construction, 28 ; keeping food from, 30 ; disposal of dead, 31 ; fourfooted enemies, 31 ; co-operation in subduing, 34 ; traps for, 303 .

Rat, cotton, 68.
Recipe for cooking muskrat, 82.

Red-backed mouse, 53.

Red squirrel, 126; home of, 127 ; food of, 128 ; preparations for winter, 131 .

Remedies for injured trees, 175.

Rodents, suppression of as pests, 184; foolish destruction of their enemies, 184; weasel tribe best police, 185; useful aid by birds, 187; aid from serpents, 188 ; poisoning and fumigation, 189; flooding burrows, 191 ; difficulty of extermination, 191 .

Sable, 242.

Salamander, 112.

Serpents as destroyers of rodents, 188.

Seton, Ernest Thompson, 47, 110, 122, 253, 262.

Shrews, 199.

Skunks, 270; skunk farming, 271.

Squirrel, 125 et seq.; treesquirrel, 125; red-squirrel, 126; gray and fox squirrels, 133; flying squirrel, 138; ground squirrel, 144; squirrels and $\mathrm{bubon}$ i $\mathrm{c}$ plague, 151.

Spermophile, 148.

Star-nosed mole, 198. 
Striped gopher, 148, 150.

Trade-rat, 101.

Traps, for mink, 257; for rats and mice, 303 ; barrel trap, 305 ; for gophers, 307 ; for rabbits, 309; for coyotes, 311.

Tree-protectors and washes, 71.

Trees, to protect from mice, 70 ; from rabbits, 173 ; remedies for injured, 74 .

Texan mush-hog, 282.

Vampire, 20.

Vermin, directions for extermination, 288 et seq.

Virginia deer, 278.

Voles, American, 50.
Wapiti, 273; raising for profit, 276.

Water-rat, 76.

Wash for protection against mice, 73 ; against rabbits, 175.

Weasel, 247; and chickens, 248 ; as a mouser, 249.

Weasels, enemies of rats, 32 ; and rodents, 242.

White tarl deer, 279 .

Wichita National Game Refuge, 286.

Woodchuck, 160.

Wood-mouse, 105.

Wood-rats, 98.

Wolverine, 243.

Wolves, 232 et seq.; poison for, 303 .

Yerkes, Prof. Robert M., 39. 




$$
\text { IN } 13 \quad 1911
$$


One copy del. to Cat. Div.

IIIN $13 \quad 1911$ 


\section{LIBRARY OF CONGRESS}

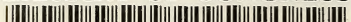

1.

00008790760 